UNIVERSIDADE DE BRASÍLIA

FACULDADE DE EDUCAÇÃO

PROGRAMA DE PÓS-GRADUAÇÃO EM EDUCAÇÃO

\title{
CORPO SENTIDO: CORPOREIDADE E A EMERGÊNCIA DE RECURSOS SUBJETIVOS ASSOCIADOS À CRIATIVIDADE
}

\author{
VICTOR LINO BERNARDES
}

BRASÍLIA-DF

2016 
UNIVERSIDADE DE BRASÍLIA

FACULDADE DE EDUCAÇÃO

PROGRAMA DE PÓS-GRADUAÇÃO EM EDUCAÇÃO

\title{
CORPO SENTIDO: CORPOREIDADE E A EMERGÊNCIA DE RECURSOS SUBJETIVOS ASSOCIADOS À CRIATIVIDADE
}

\author{
VICTOR LINO BERNARDES
}

\begin{abstract}
Dissertação de mestrado apresentada ao Programa de Pós-Graduação em Educação da Universidade de Brasília/UnB como parte dos requisitos para a obtenção do título de Mestre em Educação, na área de Escola, Aprendizagem, Ação Pedagógica e Subjetividade na Educação.
\end{abstract}

\author{
Orientadora: \\ Prof $^{a}$. Dr ${ }^{\mathrm{a}}$. Albertina Mitjáns Martínez \\ Universidade de Braíslia - Faculdade de Educação
}

BRASÍLIA, março de 2016 
UNIVERSIDADE DE BRASÍLIA

FACULDADE DE EDUCAÇÃO

PROGRAMA DE PÓS-GRADUAÇÃO EMM EDUCAÇÃO

DISSERTACÃ̃O DE MESTRADO

\section{CORPO SENTIDO: CORPOREIDADE E A EMERGÊNCIA DE RECURSOS SUBJETIVOS ASSOCIADOS À CRIATIVIDADE}

VICTOR LINO BERNARDES

BANCA EXAMINADORA

Examinador: Prof. Dr. Alexandre Luiz Gonçalves de Rezende

Universidade de Brasília - Faculdade de Educação Física

Orientadora: Profa ${ }^{\text {. Dr}}$. Albertina Mitjáns Martínez

Universidade de Brasília - Faculdade de Educação

Examinadora: Prof ${ }^{a}$. Drª. Vera Margarida Lessa Catalão

Universidade de Brasília - Faculdade de Educação

Suplente: Profa ${ }^{\mathrm{a}}$. Dr ${ }^{\mathrm{a}}$. Maristela Rossato

Universidade de Brasília - Instituto de Psicologia 


\section{AGRADECIMENTOS}

Agradeço a Vida e a todos que me auxiliaram neste trabalho. Agradeço a professora Albertina Mitjáns Martínez por sua ilustre existência, por sua revolução silenciosa, sensibilidade, carinho e humanidade. Agradeço ao professor Fernando González Rey por sua produção teórica, por sua inspiradora alegria ao lidar com as coisas da vida e pelo que sua teoria nos permite vislumbrar e criar. Agradeço ao querido grupo de estudos em Criatividade e Subjetividade, a continuidade de nossas discussões e nossos encontros foram força vital para a realização deste trabalho. Agradeço ao professor Dhyan Kapish por sua amizade e principalmente por me auxiliar, em tempos caóticos, a relembrar partes esquecidas de mim. Agradeço ao grupo Motrisofia da Faculdade de Educação Física da Universidade de Brasília por me permitirem dialogar e aprender mais sobre o corpo com quem dele entende, por fazerem não me sentir tão estranho em minhas inquietações. Agradeço a minha família, pelo apoio que me deram durante o processo do mestrado. Agradeço a Daniela, por nossas aventuras, por nossos diálogos sobre subjetividade e corpo, por nossa inquieta postura diante da vida e por partilharmos o desejo de a cada dia nos tornarmos seres melhores. Agradeço a Giovana, minha filha, que apesar de ainda estar por chegar já me enche de alegria. Agradeço aos meus amigos e amigas, por me darem força nos momentos difíceis. Agradeço às amáveis pessoas que se disponibilizaram para participar da pesquisa, me tornar amigo delas foi me redescobrir. Agradeço meu corpo que sustentou grandes momentos de imobilidade enquanto escrevíamos o trabalho, por me transmitir alegrias, dores, intuições e inarráveis sentimentos que clareiam o caminho. Agradeço as árvores que envolvem a Faculdade de Educação, por seu verde vivo e por suas sombras frescas que me acolheram em curtos momentos de repouso em tempos corridos. Agradeço a sabedoria dos antigos por me permitirem olhar as coisas de outros ângulos. 


\section{RESUMO}

O presente trabalho busca compreender o impacto do curso Corporeidade e Expressão Corporal e do Projeto de Extensão Universitária Movi-mente na subjetividade de seus participantes, com foco na emergência de recursos subjetivos associados à criatividade. O referencial teórico utilizado na pesquisa foi a Teoria da Subjetividade de González Rey, a concepção de criatividade como um complexo processo subjetivo de Albertina Mitjáns Martínez e a psicologia humanista de Abraham Maslow e Carl Rogers. A pesquisa caracterizada como Estudo de Caso, foi realizada utilizando os princípios da Epistemologia Qualitativa onde a produção do conhecimento se dá através da análise construtivo-interpretativa. No curso/projeto o corpo é abordado de forma multicultural e espiritual, o corpo se torna um laboratório com o objetivo de desenvolver consciência corporal e atingir a experiência meditativa. Foi realizado um intenso trabalho de campo que incluiu nossa participação nas aulas e nas práticas. $\mathrm{O}$ estudo de caso foi realizado com dois sujeitos utilizando os instrumentos: dinâmica conversasional, completamento de frases, análise documental, análise do facebook e composição. Ao analisarmos os casos foi possível articular uma relação entre Corporeidade, Subjetividade e Criatividade. Observamos como uma experiência, onde organizam-se práticas corporais com o objetivo de autoconhecimento, tem desdobramentos na subjetividade de seus participantes favorecendo a emergência de recursos subjetivos associados à criatividade.

Palavras-chave: Subjetividade, criatividade, corporeidade, meditação e sabedoria antiga

\section{ABSTRACT}

The present work tries to understand the impact of the Corporeity and Corporeal Expression course and the Universitary Extension Project Movi-mente in the subjectivity of the participants, focusing in the emergence of subjective resources associated with creativity. The theoretical aproach used in the research was the Subjectivity Theory developed by González Rey, the conception of creativity as a complex subjectivity process developed by Albertina Mitjáns Martínez and the humanist psychology developed by Abraham Maslow and Carl Rogers. The research characterized as Case Study, was realized using the principles of Qualitative Epistemology where the production of the aknowledge happens through the constructive-interpretative analyses. In the course/project the body has a multicultural 
and spiritual approach, the body becomes a laboratory with the purpose to develope body awareness and achieve the meditative expirience. It was realized an intense fieldwork wich included our participation in the classes and practices. The case study was made with two subjects using the instruments: conversasional dynamics, frase accomplishment, documental analyses, facebook analyses and composition. Through the case analyses we were able to articulate a relation between Corporeity, Subjectivity and Creativity. We observed how an expirience where corporeal practices are used with the purpose of self-aknowledge, had na impact in the subjectivity of the participants contributing for the emergence of subjective resources associated with creativity.

Key-words: Subjectivity, creativity, corporeity, meditation and ancient wisdom 


\section{Sumário}

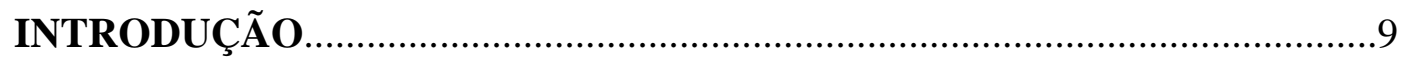

I - APORTES TEÓRICOS ...........................................................................18

1. TEORIA DA SUBJETIVIDADE E CRIATIVIDADE...........................................18

1.1. Subjetividade, sentido subjetivo e configurações subjetivas...................19

1.2. Personalidade e sujeito.......................................................................22

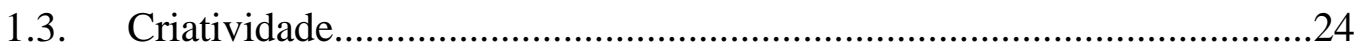

1.4. Criatividade como processo da subjetividade.........................................28

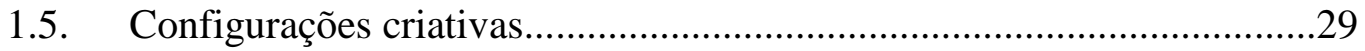

1.6. Contribuição humanista e a sabedoria antiga...........................................32

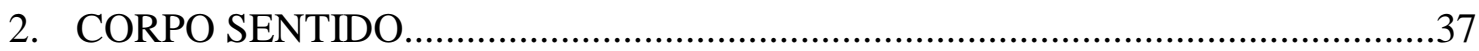

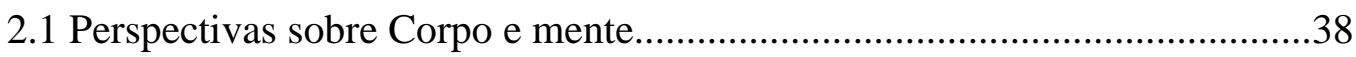

2.2 Corpo e Criatividade: Refletindo sobre as contribuições do corpo/mente no desenvolvimento da criatividade...............................................................45

2.3 Movi-mente: Meditação através do movimento. Onde o Kaos Criativo

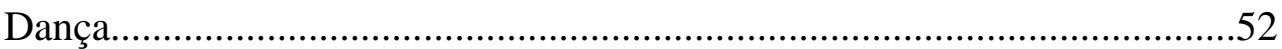

\section{II - FUNDAMENTOS EPISTEMOLÓGICOS E METODOLÓGICOS}

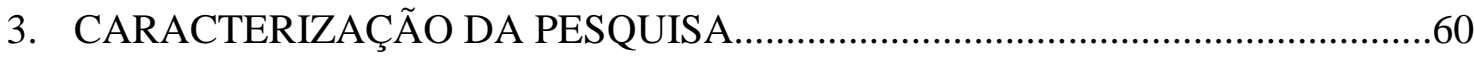

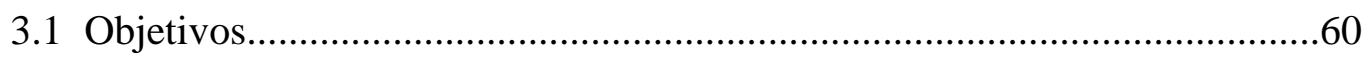

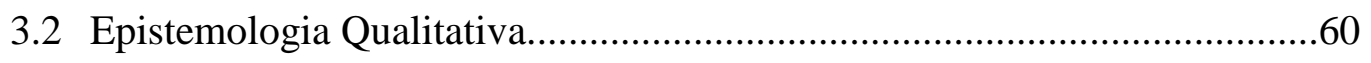

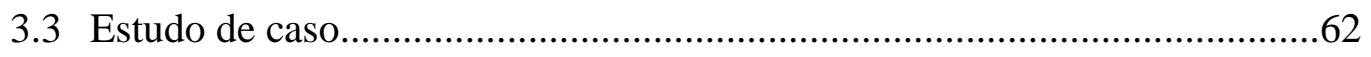

3.4 Contexto de Pesquisa: O curso Corporeidade e o projeto de extensão

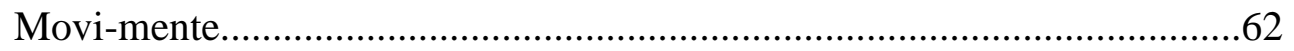

3.5 Construção do cenário social de pesquisa................................................69

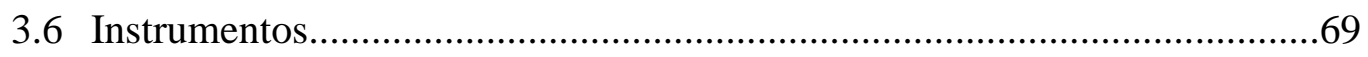

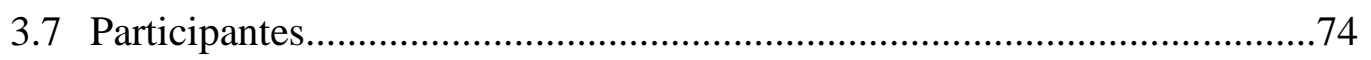

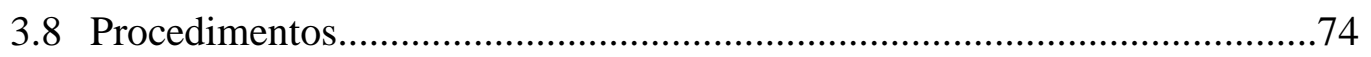

3.9 Formas de análise/ construção da informação...........................................77

4. ANÁLISE E CONSTRUÇÃO DA INFORMAÇÃO .............................................78

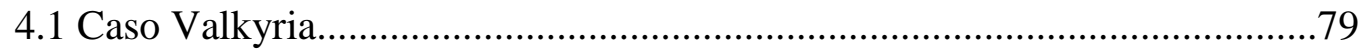

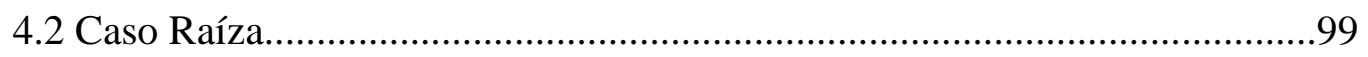




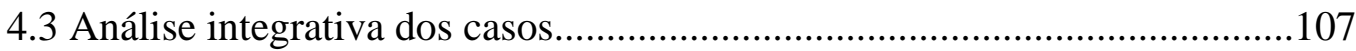

5. IMPERMANENTES CONSIDERAÇÕES FINAIS...........................................112

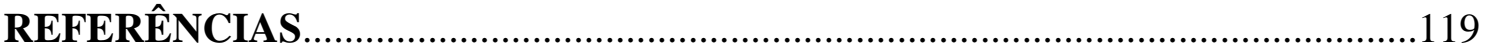

ANEXOS

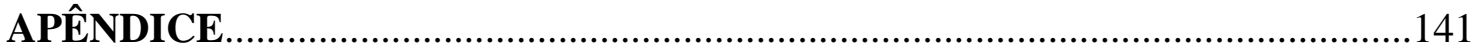




\section{INTRODUÇÃO}

Atravessamos a primeira década do século XXI, a humanidade acompanha uma série de fenômenos sociais, o emergir de novas identidades, o choque de culturas, a ocidentalização do mundo através do capitalismo, mudanças climáticas, a revolução das ferramentas de comunicação e vemos em alguns países, acalorar-se o debate em função da insatisfação do povo diante da forma como vem sendo conduzidas as questões políticas. Adentramos a era da planetariedade, as distâncias físicas existentes no globo foram reduzidas, as decisões e ações tomadas em um determinado espaço rapidamente repercutem em nível global.

Alguns autores categoricamente afirmam que o ser humano moderno vive uma crise multidimensional, uma crise de percepção (CAPRA; EICHEMBERG, 2006); uma crise epistemológica (MORIN, 2007). A crise enfrentada pelo seres humanos se expressa na ausência de uma existência humana capaz de perceber a interdependência inerente a tudo o que existe, o fio sutil que liga todas as coisas (MORIN, 2000). Nos tornamos insensíveis às nossas emergências individuais e coletivas.

Criamos barreiras entre nós como pessoas e barreiras comunicacionais entre as diversas áreas do conhecimento, ou seja, desarticulamos nossa faculdade de dialogar e se relacionar com o outro, com o diferente, com o estranho, dificultamos a comunhão necessária para que possamos nos educar de forma transformadora (FREIRE, 1981). Tais questões mantêm íntima relação com os sentidos atribuídos ao processo de constituição dos saberes ao longo do tempo e o desdobramento deste processo na constituição de sentidos que permeiam nossa leitura do mundo, de nós mesmos e dos diversos outros.

A questão da forma utilizada para conhecermos e produzirmos saberes no mundo merece cuidadosa observação, pois ao nos debruçarmos sobre um objeto de estudo e utilizarmos uma determinada metodologia, seremos constituídos pela mesma. Se a metodologia é fragmentadora, aumentamos a probabilidade de nos tornarmos fragmentados, de passarmos a viver de forma fragmentada e educarmos para fragmentação. A partir do momento que, para conhecer o mundo, Descartes reifica a divisão entre o individuo que pensa e o objeto de entendimento, temos retalhado a realidade para compreendê-la. 
Não há dúvidas de que tal visão teve significativa contribuição na produção de conhecimentos e tecnologias que tem sua utilidade para a humanidade, porém acabamos por perder a perspectiva que percebe aquilo que está integrado e as relações existentes entre o observador e observado. Na perda da percepção das relações, também perdemos a habilidade de nos relacionarmos com os acontecimentos de maneira complexa.

Entretanto, o presente não é estático e a impermanência também se manifesta na cultura e nos paradigmas que orientam as visões das pessoas de determinado tempo histórico. Neste momento limite ou de crise, irrompe a transformação. Os chineses entendem a palavra crise como sinônimo de possibilidade. Possibilidade de percebermos as lacunas; percebermos as potencialidades e limitações do momento para que, a partir daí, possamos criar uma alternativa. Urge a necessidade de uma reconfiguração do perceber e do conhecer que nos permitam vivênciar o mundo e a nós mesmos de maneira integrada e se possível integral, criando possibilidades de interação com a vida que respeitem seu caráter sensível e complexo.

Para isso, faz-se necessário reconfigurarmos nossa percepção acerca de nosso movimento epistemológico concebendo sua complexidade, o que significa reconhecer a nós mesmos e o mundo em seu caráter previsível, ordenado, definido e linear, mas, sem perder de vista a paradoxal percepção de que simultaneamente participam desta complexidade o imprevisível, a desordem, o ambíguo e o não linear. Desta forma, admitimos outros elementos participantes da constituição dos fenômenos, sem perdermos de vista as relações existentes entre as partes constituintes do todo e que cada parte possui em si o todo (MORIN, 2007).

O momento limite ou de crise se torna crucial, pois nele teremos que usar nossa criatividade e imaginação para construirmos a ponte que nos conduzirá à transcendência do vivido ou como diria o físico Amit Goswami (2008), nos possibilitará o salto quântico rumo a um novo nível de complexidade e organização. Seja lá qual forem as limitações que uma pesquisa possa vir a elencar ou a crise que ela possa vir a expressar, saberemos que, sempre, ao final, o que possibilitará sua transcendência será justamente a fantástica faculdade humana de criar alternativas para a superação de seus limites.

Nós, educadores e pesquisadores da educação vivemos o constante momento onde temos de pensar aquilo que seja importante para a educação daqueles que chegam a este planeta, desta forma, se nos importamos com o futuro do planeta Terra e com o 
bem-estar das próximas gerações, hemos de convir que se torna inalienável aos seres humanos uma educação que lhes permita o desenvolvimento e expressão de sua sensibilidade e criatividade.

Apesar de estarmos conscientes dos problemas de hoje, não estamos conscientes dos problemas que surgirão no futuro, mas de antemão já sabemos que certamente será a criatividade quem colaborará para que encontremos uma alternativa para nossas emergências. Este processo demanda pessoas capazes de sentir as necessidades de um determinado momento ao mesmo tempo que nele se sintam solidariamente engajadas, para criar soluções para as mais diversas situações que surgem no cotidiano.

Foi pensando no tema da percepção e de diferentes cosmovisões acerca do corpo/mente que regulam as formas com as quais sentimos as necessidades e nos sentimos em relação a um contexto, que fomos levados a nos questionar sobre as relações entre corpo e mente, experiência, subjetividade, a constituição da personalidade e a expressão criativa.

É através do corpo que as portas sensoriais tocam o mundo, o corpo humano é a possibilidade do cosmos tornar-se consciente de que é cosmos. O homo sapiens simboliza esta incrível possibilidade, quando olha para as estrelas. Através dos ouvidos, captaremos pelas primeiras vezes os diversos sons que ocorrem dentro do ventre materno, e será também através deles que poderemos ouvir as primeiras palavras, que numa combinação com as expressões da mãe, captadas por nossos olhos, aliados a outros processos, nos transmitirão sensações que serão percebidas como alegria ou sofrimento.

Quando a estrutura corpórea está arranjada de modo que experienciamos uma privação sensorial, por exemplo tapar os ouvidos, nós encontramos alguma forma de utilizar nossa estrutura sensorial corpórea para ler, traduzir e criar o mundo e a nós mesmos. Por intermédio do corpo e da mente nos relacionamos, nos comunicamos, acessamos a cultura, produzimos sentidos, nos singularizamos, nos tornamos humanos e tecemos o mundo. É através de corpo e mente que os humanos atribuem sentido ao mundo e através desses sentidos ele se constitui e conhece a si mesmo (MERLEAUPONTY, 1999). Desta forma, a concepção de corpo e mente de uma determinada cultura, influencia na forma como esta produz conhecimento e concebe a realidade. 
O paradigma newtoniano-cartesiano, para conhecer corpo e mente os separou, atribuindo o corpo à biologia e à nossa dimensão psicológica reservamos os campos da filosofia ou da psicologia que, justamente em função da ausência do que julgavam ser científico, caminha arduamente para constituir-se enquanto ciência e para isso se centrou-se majoritariamente numa perspectiva comportamental (GONZÁLEZ REY, 2003).

Encontramos na Corporeidade a via pela qual estão percorrendo aqueles que concebem a unidade corpo-mente. Na ciência ocidental, este campo se encontra num processo de construção, que é recente quando consideramos o que encontramos na antiga sabedoria de povos tradicionais.

Encontramos poucos trabalhos produzidos dentro deste campo, apresentando-se como uma vanguarda no meio acadêmico e por isso de delicado acesso. Acreditamos que o desenvolvimento de estudo no campo da corporeidade caminhe no sentido de apresentar novas perspectivas sobre o fenômeno corpomente (DYCHTWALD, 1984) e que gerem alternativas e recursos a serem pensados e articulados intencionalmente, por aqueles que pretendem realizar uma educação que nos conduza à nossa inteireza (SANTOS NETO, 2006), para atingirmos nosso pleno funcionamento (ROGERS, 1986) e para que possamos nos sentir integrados à teia da vida, conscientes de que nosso pensar, sentir e agir reverberam indefinidamente criando o mundo, transformando-o e produzindo novos contextos, que mais uma vez se desdobrarão sobre nós, ciclicamente exigindo de nós uma resposta, uma dança criativa.

Para a realização deste estudo entendemos que a pesquisa qualitativa seria apropriada e nos surpreendemos com as possibilidades que se abrem a partir da Epistemologia Qualitativa de Fernando González Rey no que concerne a investigação da subjetividade.

O que nos desperta interesse no tema se inicia em nossa passagem pela área de Educação Ambiental durante o curso de Pedagogia na Universidade de Brasília (UnB) e projetos de extensão. Entre 2009 e 2012 estivemos em contato com o projeto de extensão Clube de Yoga Mover Juntos, com Movimento Expressivo Vital do Sistema Rio Aberto e o projeto da Faculdade de Educação Física (FEF) o Movi-mente sendo que neste projeto, antes do professor Marcelo de Brito se afastasse para Portugal para a 
realização de seu doutorado, participamos juntos de um grupo de estudos sobre os fundamentos teóricos do Movi-mente.

Através do Programa de Educação Tutorial em Educação da UnB (PET-Edu) estivemos em contato com a Associação dos Estudantes Indígenas do Distrito Federal numa busca pela defesa de seus direitos junto ao convênio entre Fundação Nacional do Índio (FUNAI) e UnB, tal contato fora muito forte no sentido de nos apresentar aspectos da cosmologia indígena, outros olhares e conceber outras formas de existência no mundo, que apesar de esquecidas por uma parcela de nossa população, fazem parte de nossa própria história.

Em nossa participação dentro do PET-Edu, desenvolvemos o projeto de extensão em pedagogia alternativa chamado Lente Aberta, esta oficina funcionava como um laboratório de experiências com nossos corpos e era permeada por diálogos sobre temas considerados relevantes pelos estudantes. Foi realizado no Centro de Ensino Médio da Asa Norte (CEAN). Este projeto realmente nos tocou profundamente ao percebermos o quanto poderíamos crescer em grupo, a partir de uma pedagogia que buscava desencadear um processo de conhecimento sobre si, sobre o outro e os contextos em que nos relacionamos. Este projeto já era fruto de uma caminhada dentro de projetos que encontravam nas práticas que concebem a unidade corpo-mente, formas do indivíduo conhecer a si mesmo e através de um processo de conscientização, libertar-se de aspectos inconscientes, internos ou externos, que lhe oprimem e geram opressão.

Para além dos projetos dentro da universidade, outro momento gerador de reflexões e questionamentos que impulsionam este trabalho, emerge de alguns anos de estudo e prática de meditação budista e hatha yoga. O que foi decisivo para despertar em nós a força para produzir este trabalho são alguns anos em contato com a obra de acadêmicos ocidentais como Fritjof Capra, Stanislav Grof, Ken Wilber e Daniel Goleman, autores considerados polêmicos por muitos, por buscarem uma aproximação entre a perspectiva de tradições de sabedoria antiga do oriente e seu respectivo campo de produção acadêmica. Dentre os autores citados todos buscam de alguma forma, evidenciar o potencial transformador do indivíduo a partir do contacto com tais práticas e com os estados de consciência que desdobram delas.

O ponto de contato entre tais práticas é sua busca por propiciar ao praticante um conhecimento maior sobre a condição humana, para que a partir desta compreensão o 
indivíduo possa se relacionar consigo e com o outro de modo a abandonar aquilo que sinta não ser benéfico e aderir aquilo que sinta proporcionar benesses a ele e à vida como um todo. Esses movimentos transferem toda a responsabilidade ao indivíduo pelas alegrias ou tristezas que sente. Em todas elas, o corpo será utilizado como um veículo para se chegar até este conhecimento que liberta o ser de percepções que lhe geram sofrimento. Este conhecimento não pode ser compreendido apenas intelectualmente, e nem pode ser ensinado por alguém, ele precisa emergir de uma experiência que acontece na moldura do próprio corpo.

Em diversas conversas, escutávamos das pessoas, que sua participação nesses projetos tinha sido fundamental em suas vidas e que provocaram significativa transformação na pessoa que eram. Não são poucas as pessoas que dizem que eram completamente diferentes antes de viverem tais experiências. Foi interessante notar que tais transformações não eram reportadas a nível corpóreo. As pessoas não falavam de seus corpos num sentido de que haviam obtido benefícios físicos, todos relatavam como suas visões sobre mundo, sobre si mesmo e sobre os outros haviam se transformado, consequentemente transformando suas formas de se relacionar com os mesmos.

Os relatos nos indicavam que a partir desses momentos, as pessoas se sentiam mais reflexivas, autônomas, confiantes e espontâneas, com maior grau de aceitação em relação a si mesmo e alguns pareciam ter desenvolvido um forte sentimento de pertença em relação ao todo, como se simplesmente se sentissem bem por sentirem-se integradas à interdependente teia da vida.

Começamos a nos perguntar, que transformações eram essas? Como esses trabalhos com o corpo poderiam alterar as percepções das pessoas? Como corpo se relaciona com subjetividade? Como a subjetividade impacta na maneira como nos constituímos corporalmente? Como será que essas práticas contribuem para um processo de saúde mental e física, do indivíduo e da sociedade? Quais impactos na subjetividade das pessoas que participam dessas práticas?

Buscando investigar este impacto, precisamos encontrar um ponto de referência que nos sirva de base para hipotetizarmos possíveis transformações. Aportados na concepção da Criatividade enquanto um complexo processo subjetivo, desenvolvida por Albertina Mitjáns Martínez (1997, 2001, 2002, 2008, 2009), investigaremos quais 
elementos subjetivos emergem naqueles que participam de tais práticas e em que contribuem para o desenvolvimento da criatividade.

Para a realização do estudo selecionamos dois espaços, o curso Corporeidade e Expressão Corporal e o Projeto de Extensão Movi-mente, ambos sediados pela $\mathrm{FEF} / \mathrm{UnB}$. A curso se articula junto ao projeto, ambos apresentam diversos pontos de vista sobre esta perspectiva que concebe a unidade corpo-mente. Para além da dimensão teórica, os alunos participam de motrivivências com o objetivo de que o conhecimento deixe sua dimensão teórica, para que os estudantes possam vivenciar o sentimento de unidade.

Este trabalho não tem a pretensão de esgotar-se e muito menos de colocar pontos finais. Entendemos a necessidade de nos articularmos com outras áreas do conhecimento, de criarmos elos de comunicação entre elas e principalmente, de reconhecer seu caráter inacabado, aberto para futuras contribuições daqueles que por esta reflexão e prática se interessarem. Esperamos que esta seja uma contribuição para aqueles que buscam a integração de conhecimentos aparentemente díspares, e que também possa nos servir de auxílio no caminho onde buscamos integrar o sentir, o pensar e o agir, manifestando coerência.

Na era da especialização não podemos perder de vista o invisível elo existente entre todas as coisas. Este é um dos desafios da educação no século XXI, construir pontes de comunicação entre os diferentes, enxergar os elos existentes entre os ditos inconciliáveis e assim reestruturando nossa percepção, para que possamos nos sentir integrados e re-encantados com a vida.

Para realizarmos tal comunicação, não podemos deixar de lado a inseparável comunicação entre nossos corpos e mentes, eles podem ser a via para que nós nos experienciemos como partes integrantes de um processo maior. E assim, aonde vemos divisão, talvez passemos a ver integração. A partir deste ponto abrem-se oportunidades para a emergência de novas percepções, uma percepção complexa que concebe que um elo sempre é solidário ao outro.

Para ampliarmos nossa percepção, é importante revisitarmos perspectivas que, com o advento da ciência moderna, demos por ultrapassados. As diversas concepções de 
corpo e mente ao longo da história, permeiam o fazer de um determinado povo, permeiam não só seu ato criativo, mas toda sua existência e relação com o mundo.

Um outro desafio com o qual queremos contribuir, é da construção de uma educação para o desenvolvimento da faculdade de intuir e que nos incite a coragem de criar (MAY, 1982), para que, sem medo, possamos romper com máscaras criadas para satisfazermos alguma convenção, para adentrarmos a forma ou norma para atendermos sonhos que não foram arquitetados por nós.

Movimentamo-nos para que a educação do século XXI nos permita conhecer nossos próprios sonhos e nos auxiliem a cultivar um espírito corajoso, para que sejamos capazes de realizar aquilo que sonhamos e intuímos. Buscamos contribuir para uma educação que amplie as possibilidades de emergirmos enquanto sujeitos (GONZÁLEZ REY, 1997, 2002, 2003, 2004, 2005b, 2011) de nosso próprio fazer e conhecer no mundo.

O trabalho que vamos apresentar está dividido em duas partes, na primeira estão os aportes teóricos que expressam o caminho que trilhamos e que foi constituindo as lentes necessárias para realizarmos a leitura e interpretação da realidade que iremos penetrar e que nos permitirão o processo de elaboração das informações que se dará na sequência. Na segunda parte, encontraremos os fundamentos epistemológicos e metodológicos que delinearão nossas atividades durante a pesquisa.

No primeiro capítulo faremos uma breve introdução sobre a Teoria da Subjetividade de Fernando González Rey onde explicaremos alguns conceitos chave que fundamentam não só uma dimensão teórica do trabalho, mas participam efetivamente da Epistemologia Qualitativa, marco assumido por nós para a realização do trabalho.

Ainda no primeiro capítulo também apresentaremos as contribuições da teoria da criatividade de Albertina Mitjáns Martínez, sua distinta visão da criatividade como um processo da subjetividade e sua perspectiva de desenvolvimento da mesma, explicitam a forma como temos compreendido a criatividade e de que forma iremos pesquisa-la.

No segundo capítulo Corpo Sentido, apresentaremos como corpo e mente foram tratados ao longo da história transitando tanto entre perspectivas do ocidente como 
oriente e como pensamos a articulação entre as práticas que tem como premissa a unidade corpo-mente e seu impacto na subjetividade e desenvolvimento da criatividade.

Na segunda parte do trabalho o terceiro capítulo apresentará o contexto da pesquisa, a disciplina Corporeidade e Expressão Corporal e o projeto Movi-mente, exemplos concretos de uma pedagogia que objetiva o desenvolvimento do ser humano concebendo sua unidade corpomental. Ainda no terceiro capítulo também se encontram os objetivos da pesquisa e os caminhos que trilharemos para realizá-la. No quarto capítulo encontraremos os estudos de caso e a análise integrativa dos casos. E finalmente no quinto capítulo encontraremos as impermanentes considerações finais. 


\section{I - APORTES TEÓRICOS}

O Tao que pode ser expressado, não é o Tao Absoluto.

Lao Tzu, Tao Te Ching (460 a.C.)

Dizem que o que todos procuramos é um sentido para a vida. Não penso que seja assim. Penso que o que estamos procurando é uma experiência de estar vivo, de modo que nossas experiências de vida, no plano puramente físico, tenham ressonância no interior do nosso ser e da nossa realidade mais íntima, de modo que realmente sintamos o enlevo de estarmos vivos.

Joseph Campbell, O Poder do Mito (1990)

\section{Teoria da Subjetividade e Criatividade}

Quando chegamos a este planeta, entramos em contato com outros que por aqui estavam antes de nossa chegada, seres que desenvolveram sua humanidade dentro de um sistema cultural. Nós, em contato com este sistema cultural, temo-lo como base para emergirmos enquanto seres pensantes, sensíveis e intencionais. E somos capazes de criar o que ainda não existe dentro deste sistema, de transformá-lo e de sermos transformados por nossas criações.

A teoria da subjetividade nos traz de volta ao papel do indivíduo e não o separa do social. A pessoa não é vista como uma máquina isolada refletora do social, ela se constituí através de suas ações dentro de espaços sociais, criando-o, alterando-o, participando da constituição de outros indivíduos e se transformando, simultaneamente.

Reconhecemos o esforço que tem sido feito por González Rey (1997, 2002, 2003, 2004, 2011) em produzir um modelo de representação da psique que devolva a nós uma compreensão de que o funcionamento dos seres humanos é complexo e não corresponde a uma lógica de causalidade linear.

A teoria da subjetividade aliada à epistemologia qualitativa, nos parece ser de grande valor para o campo da educação, pois se apresenta como um veículo útil para atingirmos saberes inalienáveis à prática educativa, tais como atender os educandos em sua especificidade, respeitar a autonomia do ser do educando, respeitar seus saberes e, talvez o mais difícil em condições adversas, querer-lhes bem (FREIRE, 1996). 
Não vemos como colocar esses saberes em prática senão conseguirmos conhecer nossos educandos com um mínimo de profundidade e a teoria da subjetividade, parece permitir ao pesquisador, buscar formas de entender os indivíduos com profundidade.

Outro aspecto importante, é que podemos alcançar um outra zona de compreensão sobre o impacto de nossa prática educativa e tentar "sentir através do outro", em um legítimo exercício de alteridade. O termo aparece entre aspas porque não nos propomos a realizar tal façanha, mas nos dedicamos a compreender como as formas com que nos relacionamos com o espaço pedagógico impactam o desenvolvimento dos educandos. Assim caminhamos rumo à compreensão de suas necessidades para que possamos auxiliá-los a crescer.

O motivo pelo qual adentramos a teoria da subjetividade está relacionado com a forma como o indivíduo é entendido e como se constitui, e por estruturar um conhecimento que nos permitirá hipotetizar o que lhe acontece a nível subjetivo.

\subsection{Subjetividade, sentido subjetivo e configurações subjetivas}

Para começarmos a falar da subjetividade, é importante nos lembrarmos de seu caráter ontológico (GONZÁLEZ REY, 2003). A subjetividade existe como um complexo processo de funcionamento psicológico humano; os humanos funcionam complexamente, isto tem existência independente dos sistemas de inteligibilidade que são desenvolvidos para representá-lo com fins de atingir compreensão sobre tal funcionamento.

Assim como na física, investigaremos fenômenos e para investigá-los criaremos conceitos, na psicologia, construiremos um sistema representativo, que é subjetivo, para darmos inteligibilidade a um segmento do real. É por esta razão que abrimos este capítulo com a citação das palavras do sábio chinês Lao-tse que viveu no século IV a.C. A sabedoria diz que o Tao, que significa o Absoluto, o Eterno, que poderíamos também traduzir como o Real, apenas pode ser experienciado, pois quando expressado, colocado em palavras, o que se expressa é o Tao parcial. O complexo funcionamento psicológico pode ser experienciado, mas a teoria da subjetividade não é este processo em si, ela é um sistema criado para gerarmos inteligibilidade sobre este processo. Desta forma não se atribui a teoria o ônus de verdade científica irrevogável, apenas entendemos que a 
criação deste sistema pode gerar diferentes formas de inteligir o fenômeno e gerar alternativas para nos relacionarmos com o mesmo.

Na perspectiva histórico-cultural a subjetividade se desenvolve a partir das relações do indivíduo com os seres humanos de uma determinada cultura em um momento histórico. Sendo assim nesta perspectiva a subjetividade não é algo intrapsíquico ou inato, ela se desenvolve em um determinado momento desta existência, ela se constitui a partir das relações humanas.

A subjetividade é compreendida como um sistema. Este sistema é composto por unidades simbólico-emocionais, os sentidos subjetivos, que assumem uma determinada organização e se tornam partes constituintes das configurações subjetivas.

O que permitirá a singularidade dos indivíduos, é que eles não são simplesmente receptores passivos. A singularidade se produz a partir da maneira como a pessoa vivencia sua experiência, como ela a subjetiva através da produção de sentidos subjetivos. Segundo González Rey (2003):

Definimos como sentido subjetivo a unidade inseparável dos processos simbólicos e as emoções num mesmo sistema, no qual a presença de um desses elementos evoca o outro, sem que seja absorvido pelo outro. O sentido subjetivo representa uma definição ontológica diferente para a compreensão da psique como produção cultural. A integração de elementos de sentido, que emergem ante o desenvolvimento de uma atividade em diferentes áreas da vida, denominamos configurações subjetivas. (p. 127)

A maneira como integramos emocionalidade a processos simbólicos que acontecem em diferentes espaços sociais é distinta e acontecem de maneira que fogem à racionalidade, esta também constitui-se de uma emocionalidade (GONZÁLEZ REY, 2012). Neste caso existe uma relação com como as emoções de um indivíduo foram se constituindo em sua história. Essa perspectiva rompe com a ideia de que podemos ser racionais sem simultaneamente estarmos sendo emocionais. Uma racionalidade constitui-se acompanhada da história do indivíduo, de sua família, de seu povo, por isso surge junto a seus valores, suas crenças, suas experiências e sua emocionalidade.

Os sentidos subjetivos, que acompanham nossa apreensão do momento presente, possuem íntima relação com os sentidos subjetivos produzidos em outros momentos de nossa história. Esses são constituídos em outros momentos nos espaços por onde transitamos, agimos e em nossas ações não apenas no mundo concreto, mas também em 
nossas mentes enquanto refletimos. Esses sentidos subjetivos produzidos em diferentes tempo/espaço agem recursivamente contribuindo para a emergência de novos sentidos subjetivos (GONZÁLEZ REY, 2012).

Os seres humanos subjetivam seu mundo de maneira singular. Um exemplo disto pode ser notado dentro de um dos espaços que iremos investigar, o projeto de extensão Movi-mente. Existem pessoas que vão até o local, participam das motrivivências e após a saída se encontram alegres, empolgadas e extremamente comovidas. Mas também já nos foi possível perceber que, em um mesmo dia, pessoas também saíram de lá incomodadas, tristes, expressando o desejo de que não gostariam de retornar. Pessoas diferentes estão no mesmo espaço, envolvidas pela mesma prática, mas a vivenciam de maneira singular, a reação ao que se vive dentro deste espaço tem íntima relação com o que se vivencia fora dele, seja exatamente naquele dia, como também em outros momentos da história do indivíduo.

Os sentidos subjetivos, ao se organizarem, passam a constituir as configurações subjetivas. Os sentidos subjetivos não participam apenas de uma configuração subjetiva, eles podem participar simultaneamente de várias configurações subjetivas.

As configurações subjetivas são sistemas constituídos por sentidos subjetivos produzidos pelo indivíduo no decorrer de sua história. Sobre as configurações subjetivas, González Rey (2011) diz:
A configuração subjetiva expressa um sistema de sentidos subjetivos que toma as mais diversas formas nas diversas atividades e tempos da pessoa, mas através dessas diferenças podemos identificar sentidos subjetivos dominantes que marcam as expressões mais frequentes da pessoa, mas através dessas diferenças podemos identificar sentidos subjetivos dominantes que marcam as expressões mais frequentes da pessoa e seus desdobramentos no processo de viver uma experiência concreta. (p.65)

As configurações subjetivas seriam as redes constituídas por sentidos subjetivos produzidos pelo indivíduo ao longo de sua vida. Os sentidos subjetivos que se apresentarem como dominantes estruturam elementos que se expressam com maior frequência nas atitudes de um indivíduo. É importante frisarmos que quando González Rey se refere ação não resume a atividade a nível objetivo, mas também se dá a nível subjetivo, como por exemplo o ato de percepção e reflexão. 
O conceito de configurações é usado por González Rey para definir a personalidade de modo a concebermos sua processualidade, seu caráter dinâmico que está em contínuo processo de transformação e representa uma forma de organização da subjetividade individual (GONZÁLEZ REY, 2003).

\subsection{Personalidade e sujeito}

Torna-se necessário explicarmos nossa concepção sobre a personalidade, pois neste trabalho concebemos que a expressão criativa ou o funcionamento criativo do sujeito mantém relação íntima com sua personalidade compreendida como configuração de configurações subjetivas (MITJÁNS MARTíNEZ, 1997, 2008).

González Rey (2003) usa a palavra configuração para entender a personalidade como uma forma de organização da subjetividade individual. A personalidade seria uma configuração de configurações subjetivas, que participam junto a outros importantes fatores da regulação do comportamento do indivíduo.

A personalidade aqui não é vista como núcleo estático que determina o comportamento. Ela é processual, está aberta ao momento do agora onde está sendo transformada, sempre que o indivíduo produza novos sentidos subjetivos. Neste caso, o indivíduo não é necessariamente condenado a seu passado e superar-se não necessariamente trata de investigar seu passado e compreendê-lo. A pessoa pode viver experiências neste aqui e agora que serão capazes de reconfigurar suas configurações subjetivas e consequentemente sua personalidade.

Compreender a personalidade como um complexo fenômeno subjetivo nos permite ampliar nossa concepção sobre o fenômeno de constituição da criatividade, não restringindo sua expressão a específicos traços psicológicos ou qualidades (MITJÁNS MARTÍNEZ, 1997). Nesta perspectiva a criatividade se desenvolve de forma única para cada individuo, pois está relacionada com sua história de vida e como se constituiu subjetivamente.

O indivíduo que funciona criativamente é uma arrojada composição de uma série de elementos que se configuraram ao longo de sua existência, sua expressão mantém relações com recursos subjetivos constituintes da personalidade que vão permitir ou não que o mesmo interaja com o mundo criativamente. 
A personalidade não é soberana em relação a regulação do comportamento da pessoa, a personalidade é como os bonecos de um mamulengueiro, são seus recursos para realizar sua encenação. O mamulengueiro é representado pela categoria sujeito (GONZÁLEZ REY, 1997, 2002, 2003, 2004, 2005b, 2011) que representa esta individualidade, portadora de uma personalidade (MITJÁNS MARTÍNEZ, 1997). Essa personalidade é capaz de operar intencionalmente, de fazer escolhas de forma ativa e criativa, capaz de utilizar os recursos subjetivos para projetar e realizar suas ações no mundo.

$\mathrm{Na}$ teoria da subjetividade há uma distinção entre pessoa e sujeito. A pessoa pode expressar-se como sujeito, ela atua como sujeito quando está agindo de uma determinada forma. González Rey (2003) caracteriza o sujeito por sua capacidade de ruptura geradora, capacidade de gerar alternativas e fazer diferentes escolhas diante das situações vivenciadas.

As pessoas não são sujeitos a todo momento, e a atuação como sujeito está relacionada à constituição das configurações subjetivas (GONZÁLEZ REY 2003), por este motivo algumas pessoas comportam-se como sujeito em mais momentos do que outras. Uma pessoa pode se manter refém de uma situação, por não conseguir atuar como sujeito, não assumindo sua responsabilidade dentro de um determinado contexto que lhe causa insatisfação, a pessoa é assujeitada ao invés de sujeito (GONZÁLEZ REY, 2012).

As configurações subjetivas que contribuem ou não para se agir como sujeito, também possuem uma multiplicidade de fatores que a constituem, dentre elas, os sentidos subjetivos produzidos em relação aos problemas que enfrenta. O indivíduo, pode constituir-se de uma determinada forma que não o permita perceber a si mesmo como parte do problema que enfrenta, atribuindo seus conflitos apenas a fatores externos, mas jamais questionando sua contribuição para com a situação que lhe insatisfaz.

Sujeito e criatividade parecem ter uma íntima relação (MITJÁNS MARTÍNEZ, 1997, 2003), pois através do questionamento, da reflexividade, e do sentimento de responsabilidade por aquilo que se vive, o indivíduo passa a criar alternativas para as situações que lhe surgem em seu cotidiano. Se quisermos elaborar estratégias pedagógicas que contribuam para o desenvolvimento da criatividade, teremos de 
construir uma prática que nos possibilite nos constituirmos como sujeitos, exercitando nossa faculdade de questionar, de refletir, não nos restringindo a práticas que dão ênfase na memorização e reprodução de conteúdos.

O processo de reflexão, questionamento e experimentação, além de permear a didática do ensino de um conhecimento específico, como a matemática ou o português, deve também ter seu espaço próprio centrado nas pessoas e em seus corpos e na experiência de seu mundo interno. A vivência de nossos corpos, a reflexão, os questionamentos e diálogos sobre nós mesmos e nossa existência cotidiana, tornam-se importantes por propiciarem ao educando a possibilidade de, através de si, contemplar a complexidade humana destituída de obviedade. Desta forma, abrindo espaços para que os outros deixem de ser o óbvio a ser rotulado e tornem-se um estranho a ser reconhecido. Para que o indivíduo ao invés de sujeitar-se á forma padrão, à convenção, possa sentir-se a vontade para reconhecer sua singularidade e criar aquilo que intui.

Conforme caminhamos vamos compreendendo o alto nível de complexidade que expressa a teoria da subjetividade, e que nos apresenta uma distinta forma de ver o ser humano, sua constituição e a constituição de elementos subjetivos que acompanham sua ação no mundo. Apresentados alguns de seus principais conceitos, seguiremos apresentando como a criatividade é entendida dentro desta teoria e de que ponto partiremos para investigarmos como o curso Corporeidade e o projeto Movi-mente podem ser favoráveis à constituição de elementos subjetivos que contribuam para a expressão criativa dos estudantes.

\subsection{Criatividade}

No princípio criou Deus o céu e a terra.

Gênesis 1:1, Antigo Testamento (séc. X a.C.)

Eureka!

Arquimedes $(287-212)$

Ao nos depararmos com o fenômeno da criatividade nos impressionamos com seu caráter complexo e também misterioso. Constatamos sua multidimensionalidade ao percebermos que ao longo do tempo, para que se produzisse compreensão sobre este fenômeno, se constituíram distintos pontos de vista sobre a criatividade e diferentes linhas de pesquisa. 
Tem tornado-se cada vez mais reconhecida a necessidade de educarmos para a criatividade (MITJÁNS MARTINÉZ, 2006) e a criatividade tem sido veementemente veiculada como uma qualidade a ser desenvolvida, e as vezes, comercialmente, surge como uma coisa a ser adquirida por todo aquele que deseja prosperar.

Com isso vemos abrir um grande espaço para a pesquisa em criatividade e também acompanhamos uma ampla atividade no mercado de serviços e literário, proliferam-se uma série de livros e textos nas redes sociais que apresentam fórmulas mágicas, exercícios para tornar uma pessoa criativa ou alguma atividade mais criativa. Surgem os gurus da criatividade e o fenômeno coaching explode oferecendo promessas de desenvolvimento da criatividade nas empresas e no cotidiano.

Defendemos o caráter político do pesquisador que compreendendo o desenvolvimento da criatividade a partir de uma determinada perspectiva, tem como dever, informar a sociedade sobre o ganho que eventualmente possa ser feito em função de uma determinada visão. A ciência deve ser utilizada para tomarmos consciência e nos orientarmos diante das ofertas do cotidiano e também para ampliamos a possibilidade de fazermos escolhas que atendam nossas necessidades. Neste caso, o desenvolvimento de nossa expressão criativa e a elaboração de propostas educativas que objetivem o desenvolvimento da criatividade.

Educar para a criatividade é uma responsabilidade que dever ser assumida por todos aqueles que mantêm o compromisso com uma educação que permita a aprender $a$ Ser (DELORS, 1998). Veremos adiante que a perspectiva assumida por nós neste trabalho mantém relações íntimas com o desenvolvimento de elementos que auxiliariam as pessoas, não apenas em seu fazer criativo, mas principalmente, a tornarem-se seres dotados de recursos subjetivos que em muito contribuirão para seu bem-estar integral.

$\mathrm{Na}$ antiguidade a criatividade já esteve relacionada a uma inspiração divina. $\mathrm{O}$ próprio termo entusiasmo, muitas vezes referido para expressar um dos sentimentos que vive a pessoa enquanto está imersa em um processo criativo, vem da palavra grega enthusiasmos, que significa possessão divina. O fenômeno também já esteve associado à própria loucura, em função dos criativos manifestarem comportamentos que divergem dos padrões de seu tempo (WESCLHER, 1993). A criatividade, em determinados momentos, encontra resistência em função de seu caráter de ruptura e transformador. A emergência de algo novo pode significar uma reestruturação dos pólos de poder dentro 
de um determinado contexto e incentivar a criatividade, pode ser considerado uma transgressão.

O psicanalista Rollo May (1982) em seu livro A coragem de criar definiu a criatividade como o encontro do indivíduo com algo que lhe provoque um intenso desejo de criar. Entretanto, quando May expressa como criativo o encontro entre dois seres humanos e diz que a novidade deste encontro é a gênese de um novo ser. Sua compreensão sobre a criatividade está transcendendo a dimensão artística e a intencionalidade humana, pois o encontro que permite a gênese de novos seres, também se dá entre outras espécies.

A partir da compreensão de Rollo May, ampliamos o conceito de criatividade e concebemo-la como um princípio da natureza ou um princípio cósmico, que resulta em algo novo que impacta o tempo/espaço e indivíduos onde surge, transformando-o. $\mathrm{O}$ Big Bang, uma das teorias de emergência de nosso universo, por exemplo, seria o resultado da criatividade cósmica. Tal concepção de criatividade tem permeado o pensamento de físicos e de biólogos que estão assumindo uma nova compreensão sobre o conceito de vida (MATURANA; VARELA, 2005, GOSWAMI, 2008).

Na teoria da subjetividade, quando González Rey (2003) fala sobre o caráter de ruptura e produtor de alternativas do sujeito, a criatividade configura-se como princípio participante do processo de produção da subjetividade. Isto permite dizer que todos nós somos criativos, pois em determinado momento produzimos novos sentidos subjetivos que criam novas configurações subjetivas.

Outra interessante forma de pensarmos a criatividade é em relação a qualidade com que se faz algo. Pode-se lavar um chão criativamente ou realizar esta atividade sem a criatividade. O polêmico indiano, líder religioso e místico Baghwan Shree Rajneesh, também conhecido como Osho (1999), falou sobre esta qualidade e afirma a possibilidade de se viver criativamente. $\mathrm{O}$ autor faz pensar que a vida pode ser vivida de uma maneira muito mais satisfatória, caso o indivíduo, esteja criativamente realizando qualquer coisa que seja. Esse viver criativo, estaria relacionado a uma faculdade de estarmos continuamente criando sentido para as coisas que fazemos, sendo capazes de gerar um imenso prazer, que está centrada no processo de fazer, ao invés de ter ênfase na finalidade do fazer. 
Talvez seja pelo mesmo motivo que os humanistas, Abraham Maslow (1968) e Carl Rogers (1986) tenham entendido a criatividade como uma marcante característica em pessoas que consideraram felizes. Os humanistas observaram que a criatividade, enquanto uma característica da expressão do indivíduo não chega sozinha, ela chega estruturada por elementos como coragem, reflexividade, ausência de convencionalismos e aceitação de si mesmo, elementos que se constituíram na pessoa ao longo seu desenvolvimento.

O arrebatamento sentido por nós ao pesquisar o tema, é o mesmo sentido por qualquer pesquisador que percebe o objeto de estudo, em tudo o que o circunda. Nos sentimos como o químico quando em tudo percebe as moléculas de carbono, e nós, neste momento, percebemos a criatividade em tudo. Tudo o que existe, o computador que nos permite escrever este trabalho, o espaço onde estamos, nossa própria existência, as letras e a língua que utilizamos para nos expressar, em algum momento foi criada, isso no sentido de que são frutos de um processo criativo de onde emergiu algo novo, não existente previamente e que transformam o contexto onde surgem.

Várias linhas de investigação foram criadas para se pesquisar a criatividade, o que as diferencia é a própria concepção do que é a criatividade, a faceta do fenômeno que investigam e a forma utilizada para realizar e interpretar a investigação. Entre elas estão a investigação do processo de pensamento criativo, as modalidades de produção criativa, características da personalidade criativa, tipos de ambiente facilitadores da criatividade e as combinações entre elas (WECHLER,1993). Outra forma de se definir as linhas foi retomada por Alencar, Bruno-Faria e Fleith (2010) onde se dividiram os focos de pesquisa em: pessoa, processo, produto e contexto.

O caráter de novidade permeia o conceito científico de criatividade e essa novidade precisa necessariamente ter um valor. Linhas de pesquisa como a de Csikszentmihalyi (1994) defenderão justamente que algo, para ser considerado criativo, carecerá do aval de uma comunidade de referência. A criatividade investigada aqui está relacionada à big creativity (FELDMAN; CSIKSZENTMIHALYI; GARDNER, 1994) e pesquisa indivíduos com produções excepcionais. Nesta linha de pesquisa não se leva em consideração a criatividade cotidiana. São pesquisas como essas que criam representações da criatividade como algo que se restringe a gênios. 
Há perspectivas onde o valor não depende do aval de uma comunidade, o produto pode ter relevância apenas para aquele que cria e impacta seu contexto, tanto subjetivo, como o espaço social onde se relaciona (MITJÁNS MARTINEZ, 2009).

É essencial ressaltarmos as formas que tem sido utilizadas para se estudar a criatividade, pois o estudo da criatividade é permeado pela hegemonia do movimento que busca mensurar a criatividade. Primeiro quantifica-se a criatividade de acordo uma determinada ideia do que seja a mesma e depois se verifica o nível de criatividade de um indivíduo de acordo com um teste (WECHLER, 1993).

Por uma outra via seguem as pesquisas qualitativas, que apesar de serem estudos de uma outra ordem, podem também exercer uma leitura dos dados buscando uma neutralidade sem buscar ir além do dado e sem admitir que a interpretação do dado possui também um caráter subjetivo, configurando seu fazer científico muito semelhante às pesquisas quantitativas de caráter positivista (GONZÁLEZ REY, 2005). Podemos "perceber" "traços característicos" da personalidade de indivíduos criativos, mas ainda assim não conseguindo elaborar compreensões sobre como, processualmente, se desenvolve a criatividade.

Encontramos aqui o valor heurístico da pesquisa em subjetividade (GONZÁLEZ REY, 2005) quando nos permite a construção de um modelo teórico que nos auxilie na elaboração de modelos explicativos sobre o complexo processo de constituição de tais elementos participantes do sujeito criativo.

\subsection{Criatividade como processo da Subjetividade}

Para a realização deste trabalho tomaremos como marco teórico a criatividade enquanto um processo da subjetividade criada por Mitjáns Martínez (1997, 2001, 2003, 2008, 2009). Segundo Mitjáns Martínez (2001):

\footnotetext{
Assumimos a criatividade como um processo complexo da subjetividade humana na sua simultânea condição de subjetividade individual e subjetividade social que se expressa na produção de "algo" que é considerado ao mesmo tempo "novo" e "valioso" em um determinado campo da ação humana (p. 70)
}

As palavras novo e valioso aparecem entre aspas porque não se está mais se referindo apenas a um produto externo que é considerado novo e valioso por alguém ou por algum grupo de pessoas externas ao indivíduo. Considera-se também 'ação humana' 
o próprio ato de reflexão, a produção de novas ideias, proposições para a resolução de dilemas filosóficos e psicológicos, de novos entendimentos acerca de um determinado assunto ou situação que terão valor para o próprio indivíduo ${ }^{1}$.

A criatividade enquanto um processo da subjetividade não é um processo intrapsíquico, ela se constituirá através das relações com os outros nos diversos espaços sociais por onde a pessoa transita durante sua existência e também numa relação consigo mesma (MITJÁNS MARTINEZ, 2008). Nesta perspectiva não se apontam fatores biológicos e nem se atribui à criatividade um caráter de dom divino. Neste caso, toda pessoa tem, em alguma medida, a possibilidade de se constituir enquanto um sujeito criativo.

\subsection{Configurações criativas}

Para investigar a criatividade como um processo da subjetividade elaborou-se o conceito de configurações criativas (MITJÁNS MARTÍNEZ, 1997). Tais configurações seriam uma integração singular de elementos que, com relativa estabilidade, participam da configuração personológica do indivíduo e entrevêem na forma que este se expressa criativamente.

Mitjáns Martínez (1997, 2008) elenca diversas características que pesquisadores da criatividade associaram a pessoas criativas, aspectos como auto-confiança, abertura à experiência, flexibilidade, introversão, autonomia, sensibilidade e auto-valorização são frequentemente encontrados nos estudos sobre indivíduos criativos. A criatividade como um processo da subjetividade, nos abre a possibilidade de investigação do processo de constituição tais elementos em sua complexidade e singularidade, pois nesta perspectiva, tais elementos se configuram a partir das produções de sentido subjetivo durante a tensão dialética entre indivíduo e mundo.

Sobre o caráter diverso dos elementos que participam do comportamento criativo Mitjáns Martinéz (1997) faz a seguinte ressalva:

...apesar de não considerarmos que exista um perfil único de traços que caracterize todas as pessoas criativas, há, sim, qualidades sobre as quais é preciso nos debruçarmos: elementos como a flexibilidade, a ausência de inibições e de convencionalismos, a abertura à experiência

\footnotetext{
${ }^{1}$ Esta ideia que se inicia, integrada a outras, tem sido desenvolvida posteriormente pela autora no que denomina "dimensão funcional da criatividade" (2009), categoria em processo de desenvolvimento e investigação.
} 
e um alto nível de motivação intrínseca, de uma forma ou de outra, refletem-se em diferentes trabalhos com bastante força. (p.26)

As configurações criativas são configurações subjetivas, são redes que integradas por sentidos subjetivos, ou seja, são redes de unidades simbólico-emocionais produzidas na relação do indivíduo com o mundo. As configurações criativas são especificamente uma rede de sentidos subjetivos que expressam em comportamentos criativos.

A autoconfiança, por exemplo, não é um aspecto inato, ela se desenvolve conforme o indivíduo produz sentidos subjetivos que vão constituindo um sentimento de confiança do indivíduo em relação a si mesmo. Esta confiança se desenvolve em diferentes espaços sociais por onde o indivíduo transita ao longo de sua existência, em função das articulações de sentidos subjetivos produzidos em diversas experiências em diferentes espaços sociais como na escola, em casa ou no trabalho.

No estudo de Kaufman, Beghetto e Pourjalali (2011) sobre influências culturais em relação às perspectivas da criatividade, explicita-se o quanto a concepção de criatividade e de pessoas criativas irá diferenciar-se de uma cultura para outra. Os orientais estão culturalmente mais voltados a coletividade, para eles a criatividade de alguém será reconhecida caso gere algo de valor para a comunidade. Neste caso a originalidade, no sentido de se destacar do coletivo, não é necessariamente reconhecida como um aspecto relevante da pessoa criativa.

No estudo das configurações criativas não se está tentando encontrar características de uma pessoa criativa, estamos examinando como, ao longo do processo de subjetivação do experienciado, a pessoa constitui recursos, considerados constituintes, que entrevêem em sua ação no mundo permitindo que se expresse criativamente.

A metodologia utilizada dentro do Movi-mente é elaborada com o objetivo específico de permitir que os participantes vivenciem-se como se gradativamente estivessem adentrando as profundezas de seus corposmentes (DYCHTWALD, 1984), conhecendo seu íntimo, seus impulsos, sensações, emoções e pensamentos. Neste campo de possibilidades, que é o ato de conhecer a si mesmo através do próprio corpo, busca-se criar condições para que novas percepções possam emergir, promovendo a 
emergência de nova compreensão relacionada à percepção que os estudantes têm de si, do outro e do mundo.

Apesar de não haver a possibilidade de controle sobre a produção subjetiva, o projeto e o curso buscam criar condições favoráveis para que os estudantes caminhem da aversão para o acolhimento de si mesmo, do medo para a coragem, da tensão e rigidez para a alegria e espontaneidade, isso não de uma maneira mágica, mas como fruto do processo que se desencadeia em função das motrivivências aliadas a exercícios de reflexão.

Nossa hipótese é de que, neste processo, a expressão criativa pode ser desenvolvida, pode constituir-se. Se entendermos este complexo processo em um nível mais profundo, teremos a possibilidade de orientar práticas pedagógicas com objetivos específicos tais como o desenvolvimento da sensibilidade, da reflexividade, da intuitividade, da coragem, da confiança em si e da aceitação de si. Tais práticas também abrem a possibilidade de conseguirmos desencadear momentos pedagógicos capazes de nos proporcionar um verdadeiro giro paradigmático acerca das percepções de quem somos, de tornar palpável a possibilidade de nos experienciarmos como interdependentes, participantes da teia da vida.

Esta hipótese pode gerar uma zona de sentido, (GONÁLEZ REY, 2003) capaz de contribuir significativamente, no processo de construção de uma didática catalizadora dos processos educativos que intencionam o desenvolvimento da criatividade, não em um sentido produtivista, mas principalmente engajada com a saúde individual e social.

De alguma maneira parece que a perspectiva histórico-cultural da criatividade nos permite aprofundamento, que vai além das linhas teóricas, que reconheceram traços participantes da constituição de indivíduos criativos, da criatividade centrada em um produto e da perspectiva sistêmica de Csikszentmihalyi (1994). Adentraremos o território onde poderemos teorizar sobre como determinadas atividades pedagógicas, práticas e espaços sociais podem alterar a dinâmica da subjetividade individual criando possibilidades de emergência de recursos subjetivos que possam contribuir para a constituição de elementos favoráveis à expressão criativa.

Os estudos de Mitjáns Martinez (1997, 2009) e os humanistas Rollo May (1982), Abraham Maslow (1968) e Carl Rogers (1986) serão utilizados como aportes para a 
construção de indicadores sobre a constituição de elementos que participem de configurações criativas, que se desenvolvem ao longo do semestre, durante a participação dos alunos no curso Corporeidade e ao projeto Movi-mente.

Sabemos da impossibilidade de afirmarmos categoricamente que um determinado elemento configurou-se estritamente em função da passagem do indivíduo por um único espaço. Também não podemos negar que os espaços por onde as pessoas transitam e se relaciona as transforma. Sendo assim, um de nossos objetivos é investigar quais impactos este espaço possa estar tendo na subjetividade dos indivíduos.

\subsection{A contribuição humanista e a sabedoria antiga}

Os humanistas atribuem à criatividade um papel essencial no caminho da autorealização ou realização do self. O humanismo surge entre 1960 e 1970 (SCHULTZ \& SCHULTZ 2008) como uma crítica ao que eram consideradas as duas forças dominantes da psicologia, na época. O behaviorismo por seu caráter cientificista reduziu a complexidade humana ao funcionamento mecânico de um robô. A psicanálise enfocou lados emocionalmente perturbados da natureza humana.

A abordagem humanista irrompe como terceira força opondo-se a essas duas forças dominantes e centra suas investigações em aspectos positivos dos seres humanos, em suas virtudes e potencialidades (SCHULTZ \& SCHULTZ 2008). No humanismo a criatividade tem sido considerada um aspecto que expressa a saúde do indivíduo, não entendida apenas na perspectiva do produto, seu valor está centrado em um senso de satisfação advindo da interação com a vida de maneira criativa.

Abraham Maslow (1968) passa a compreender o valor da criatividade quando percebe o sentimento de satisfação nas pessoas que são capazes de inovar em pequenos atos do dia-a-dia. De acordo com a corrente humanista, os indivíduos teriam naturalmente uma inclinação para realizarem-se completamente em um processo onde gradativamente o indivíduo toma consciência de si mesmo. A criatividade é considerada um aspecto chave para que os seres humanos consigam criar os caminhos e alternativas necessárias para atingir a auto-realização (MASLOW,1968) ou seu pleno funcionamento (ROGERS, 1986). Para os humanistas seria uma busca inerente à própria natureza humana. Neste caso os seres humanos possuem uma espécie de obrigação de serem felizes, pois ser feliz faz parte de sua natureza. . 
É notável que a compreensão de Carl Rogers associe-se muito às compreensões do oriente, chegando até a usar, para se expressar, palavras semelhantes às usadas pelas tradições de sabedoria antiga. Rogers (2009) diz que existe a possibilidade da pessoa conscientizar-se do mundo tal como ele é. Na sabedoria antiga oriental, de origem budista, irão utilizar esta expressão, chegando a usá-la para nomear uma de suas principais meditações, a Vipassana, que significa ver as coisas como são (HART, 2012). Ver as coisas como são, ou ver o mundo como ele é, significa ver sem que o que Rogers (2009) chamou de categorias predeterminadas. Segundo Rogers, tais categorias distorcem nossa percepção e experiência do fenômeno, consequentemente, interferem na maneira como nos relacionamos com o mesmo e muitas vezes não nos proporcionando a realização que estamos buscando.

A meditação Vipassana popularizou-se no ocidente quando foi proposto seu ensino fora do espaço considerado religioso, principalmente nos Estados Unidos sob o nome de Mindfullness ou Awareness meditation. A meditação tem sido objeto de pesquisas no campo da neurociência, inclusive na perspectiva de sua conexão com a criatividade e o processo criativo (DING, TANG, TANG \& POSNER, 2014; CAPURSO, FABBRO \& CRESCENTINI, 2013; HORAN 2009).

Ambas as técnicas citadas orientam-se pelo treino daquilo que chamam de equânimidade diante do que é observado e sentido. Trata-se de uma postura de plena atenção que acompanha conscientemente tudo o que surge no corpo e na mente, que propõe não reagir de forma aversiva e nem ávida diante dos estímulos que surgem momento a momento. Apenas observa-se, ou como o filósofo indiano Krishnamurti (1992) disse: se está em choiceless awareness (consciente sem fazer escolhas).

O processo de contínua consciência das emoções e sensações corpóreas é descrito por Carl Rogers como uma prerrogativa para o ato criativo construtivo que beneficiará não só o indivíduo, mas também o coletivo. Rogers (2009) diz:

Na medida em que o indivíduo está aberto a todos os aspectos de sua experiência e devidamente consciente das variadas sensações e percepções que se registram no interior de seu organismo, então o produto novo da sua interação com o ambiente tenderá a ser construtivo, tanto para si como para os outros. (p.409) 
A abertura à experiência é o que permitirá a pessoa tomar consciência do momento e escolher aquilo que seja mais apropriado, utilizando a criatividade de maneira construtiva.

Abraham Maslow (1968) também expressa alguns aspectos que ele começou observar nos pacientes que considerava criativos:

Contudo, talvez fosse mais importante ainda a ausência de medo dos seus próprios íntimos, dos seus próprios impulsos, emoções e pensamentos. Eram mais propensos do que a média à aceitação de seus próprios eus. Essa aprovação e aceitação dos seus eus mais profundos possibilitava-lhes muito mais perceberem corajosamente a natureza real do mundo e tornava também mais espontâneo o seu comportamento (menos controlado, menos inibido, menos planejado, menos deliberado e "intencional"). Temiam menos os seus próprios pensamentos, mesmo quando estes eram extravagantes ou "amalucados". Tinham menos receio de que rissem deles ou de serem alvo de desaprovação. Não lhes importava serem inundados de emoção. (p.173)

O que nos chama atenção e a motivação para a realização deste estudo é perceber que aspectos como os citados por Maslow, que apesar de não serem a centralidade do ensino de tradições sapienciais antigas (a meditação budista, o yoga hindu, o tai-chi-chuan taoísta), são frequentemente narradas como qualidades secundárias que surgem no praticante, auxiliando-o em sua caminhada.

Quando explicitamos a ausência de centralidade no desenvolvimento de tais aspectos é para recordar que as tradições, apesar de versarem sobre a possibilidade de desenvolvimento dos mesmos, em última instância sempre buscam e conduzem a algo que não pode ser verbalmente expressado em sua totalidade, que pode apenas ser vivenciado.

Ao ampliarem o olhar sobre a constituição da criatividade os humanistas trazem, mesmo que incipientemente, uma atenção ao corpo humano. Rogers, como citado anteriormente, fala sobre a necessidade de consciência de nossas emoções e sensações. Rollo May (1982) explicita a necessidade de cultivarmos sensibilidade para poder criar. Explicita-se a necessidade de uma coragem física, que significa desenvolvermos através do corpo, uma capacidade de empatia que nos permita sentirmos a nós mesmos, o outro e o contexto para que criemos o que é sentido como necessidade (ROLLO MAY, 1982). Segundo Rollo May (1982): 
A liberdade humana implica a capacidade de fazer uma pausa entre o estímulo e a reação, para escolher a resposta que mais nos convém. $\mathrm{O}$ poder de criarmos o nosso eu com base nessa liberdade é inseparável do conhecimento de nós mesmos. (p.102)

Esta liberdade a que se refere Rollo May, tem uma profunda conexão com o coração da meditação budista. É a capacidade de fazer essa pausa, propiciada pelo que chamam de faculdade de equanimidade (upekkha), considerada uma das dez perfeições (paramis) que germinam na mente do praticante caso a meditação seja cultivada (HART, 2012). É apenas com este recurso que Rollo May chamou de pausa, manter-se nesta vacuidade consciente, que se tem liberdade para criar.

Se nos tornarmos conscientes ao ponto de conseguirmos realizar esta pausa poderemos, entre um estímulo e uma reação, parar, observar e sentir o que é apropriado. A partir deste ponto criamos nossa ação, nosso movimento, nossa consciente escolha e resposta à situação, de acordo com o que objetivamos. Se o ato do indivíduo é automaticamente orientado pelos estímulos ou por suas categorias predeterminadas (ROGERS, 2009), ele está reagindo de maneira autômata, está reproduzindo sem reflexividade e sem escolha, o que lhe impede de construir seu presente de forma autônoma, criativa e consciente. Sem esta liberdade o indivíduo é impedido de atuar como sujeito.

Desde o fervor cultural, vivido pelo movimento hippie anos sessenta, o ocidente tem demonstrado cada vez mais abertura para examinar a espiritualidade oriental (CAPRA; FYFIELD, 1988). Constitui-se uma forte representação na subjetividade social que as práticas meditativas do oriente, que em determinado momento dedicam-se ao cultivo do corpo e desenvolvem aspectos físicos do ser humano, contribuem também para o desenvolvimento de qualidades psicológicas. Esta representação e a busca por sua comprovação movimenta estudos tanto no campo da neurociência como também começam a ganhar espaço em estudos de metodologia qualitativa (MENEZES; DELLAGLIO, 2010) produzindo informações sobre o impacto de tais práticas.

Consideramos que o que é o proposto pela prática do Movi-mente e pelo curso de Corporeidade pode vir a facilitar a emergência de elementos que são expressados pelos humanistas como aspectos participantes de sujeitos criativos. Hipotetizamos que recursos subjetivos como abertura à experiência, extencionalidade entre outros recursos favorecedores da expressão criativa tais como a coragem, autoconfiança, reflexividade, 
flexibilidade, sensibilidade, intuitividade e aceitação de si mesmo possam ser desenvolvidos, emergindo como resultantes das práticas meditativas que possuem o corpo como sua via de realização.

Apesar de termos os aportes teóricos humanistas, junto à perspectiva históricocultural da criatividade, como arcabouço para nos orientarmos acerca do que possam ser aspectos constituintes de sujeitos criativos, compreendemos que a constituição do sujeito criativo se dá de maneira singular nos contextos culturais e históricos de ação. Por isso não especificamos em nossos objetivos quais recursos subjetivos específicos estamos centrados quando nos referimos à constituição de sujeitos criativos. Fazemos isso para ampliar a possibilidade de investigar o processo de constituição de diversos elementos passíveis de serem considerados favoráveis a expressão criativa.

Os humanistas nos fizeram refletir sobre possíveis relações entre o desenvolvimento da criatividade e as tradições de sabedoria antiga do oriente. Essas tradições entendem corpo e mente de uma perspectiva diferente da que acompanhou a visão da ciência do ocidente nos últimos anos.

No próximo capítulo, faremos uma viagem em direção ao corpo, numa busca por ampliarmos nossa reflexão sobre o mesmo. O próximo capítulo servirá como plataforma para compreendermos os objetivos do curso Corporeidade e do projeto Movi-mente, que buscam apresentar uma "nova" concepção de corpo e mente e propiciar uma experiência que permita a integração desta visão. 


\section{CORPO SENTIDO}

Então, inúmeros bhikkhus (monges) estavam sentados no salão de reuniões, onde eles se reuniram após a refeição, depois de terem esmolado alimentos, quando esta discussão teve início: "É maravilhoso, amigos, é admirável, como foi dito pelo Abençoado (Buddha) que sabe e vê, um arahant (iluminado), perfeitamente iluminado, que a consciência plena do corpo, quando desenvolvida e cultivada, produz grandes frutos e grandes benefícios."

Kayagatasati Sutta, Majjhima Nikaya 119.2 (2.500 a.C)

Sugiro uma nova forma de coragem corporal: o uso do corpo, não para o desenvolvimento exagerado de músculos, mas para o cultivo da sensibilidade. Isso significaria desenvolver a capacidade de ouvir o corpo. Seria como diz Nietzsche, um aprendizado para pensar com o corpo. Seria a valorização do corpo como um meio de criar empatia com outras pessoas, a expressão do eu como um objeto de arte e uma fonte de prazer.

Rollo May, A Coragem de Criar (1975)

O que é corpo? O que é a mente? Não é incrível pensarmos que qualquer resposta que possamos dar a tais perguntas serão sempre a expressão de um corpo que se desenvolveu em um tempo histórico e dentro de uma determinada cultura? Seja lá o que respondermos, a resposta será sempre o ponto de vista de uma corpo no tempo/espaço.

O inalienável acerca de refletir sobre questões relativas a representação de corpo e mente ao longo do tempo é que, como uma representação, entendemos que elas movimentam poder e servem como arcabouço para as ações de indivíduos no mundo.

Se concordamos que nossa crise paradigmática reside numa crise de percepção (CAPPRA; EICHEMBERG, 2006) cabe a nós produzir novas ou resgatar formas de inteligibilidade que devolvam em nós a faculdade de perceber a complexidade do real e ampliem nossas formas de interação com os fenômenos.

Nossas interações com o mundo dependem em alguma medida da forma como o concebemos. Por isso é de extremo valor questionarmos e investigarmos o impacto que deriva de representações hegemônicas dominantes na subjetividade social, com isso propor formas de concepção e interação que atendam melhor a Vida como um todo. 
Assim como a representação, amplamente difundida, de seres humanos apartados da natureza desemboca em ações que danificam o meio ambiente e comprometem seriamente as condições da Vida do planeta. Também as representações de mente separada do corpo implicam em uma ação limitada em relação aos mesmos.

O reencantamento dos corpos é aquilo que buscamos quando removemos do corpo sua obviedade e nos lançamos a ele com um olhar curioso, aberto e investigativo.

\subsection{Corpo e Mente no tempo}

Corpo e mente já foram representados de diversas formas ao longo da história. Na filosofia grega, Platão (V a IV a.C.) foi o primeiro a fazer a separação entre corpo e alma, mundo inteligível e mundo sensível. Nesta concepção o corpo era visto como um entrave ao vislumbre da alma, sua sede por desfrutar os prazeres sensoriais impedem o ser humano de contemplar a perfeição das ideias. É apenas ao final de sua obra que Platão admite que os exercícios físicos podem beneficiar a alma (GONÇALVES, 1994).

Apesar de Aristóteles, discípulo de Platão ter declarado a inseperabilidade de corpo e mente, esta separação é forte tendência no pensamento ocidental até os dias de hoje. A visão de Platão influenciou também o pensamento da igreja católica onde o corpo tendia a uma bestialidade pecaminosa, que precisava ser dominada a fim de que se pudesse viver a paz do espírito.

A separação entre corpo e mente se reforça quando Descartes (1956-1650), em sua busca por encontrar algo verdadeiro, levou até as "últimas" consequências o ato de duvidar. Descartes pensou que se pudesse chegar a uma premissa que fosse indubitável, deste local "verdadeiro" poderia desenvolver um conhecimento o qual se pudesse confiar, é de onde deriva a máxima: "cogito ergo sum!".

Descartes podia duvidar, só o podia porque se permitia pensar, se o pensamento não tivesse existência não haveria a possibilidade de dúvida. A partir desta premissa Descartes passou a entender que o pensamento e o corpo habitam espaços distintos. Mais uma vez na história reafirma-se a cisão entre corpo e mente, e dessa vez instituí-se como premissa básica da produção do saber científico.

Já em outras culturas desenvolveram-se outras compreensões sobre corpo e mente, uma percepção da unidade existente entre eles. Na tradição budista (2.500 a.C) 
já se encontra a definição de skhandas (idioma sânscrito) ou khandas (idioma páli) que significa: agregados. O serlexistência é constituído por cinco agregados: rupa (forma material), vedana (sensação), sanya (percepção), sankhara (formações volitivas) e vinyana (consciência) (RAHULA, 2005). Este sistema em movimento, que não pode ser compreendido separadamente, representa a concepção de ser/existência para a tradição budista.

Observando a concepção budista de corpo e mente percebe-se como muito antes de Merleau Ponty, que abordaremos adiante, a tradição já fazia uma representação onde distinguem sensação de percepção. Apesar da distinção, o budismo reconhece a impossibilidade de compreende-las separadamente, elas são instantes de um mesmo processo. Esta definição surge porque não possuem uma concepção de ego ou existência extática, de um sólido núcleo no interior do indivíduo tal como um eu que experimenta o mundo. Por isso sua concepção de ser/existência é intitulada de doutrina do não-eu (anatta), portanto, de uma concepção de existência processual, interdependente. O que existe é apenas um interdependente fluxo de energia em movimento (RAHULA, 2005).

O Yoga é concebido como um dos seis pontos de vista (darshana) da filosofia hindu (ELIADE, 1996, FEUERSTEIN, 1998). Um dos textos considerados mais importantes pelos estudiosos do Yoga foi a compilação feita pelo yogi, linguista e médico Patanjalim (IV a.C.), conhecido como os Sutras de Patanjalim. Em alguns trechos Patanjalim exprime como o trabalho com o corpo através da realização dos ásanas (posturas psicofísicas), os pranayamas (controle da respiração), permitem que o praticante atinja uma libertadora quietude mental (IYENGAR, 2001).

A quietude mental é uma das vias para a realização do estado de samadhi, que em alguns contextos é traduzido por profunda meditação. De acordo com Eliade (1996) e Feuerstein (1998) significa estar dentro do $\mathrm{Si}$ mesmo, dentro da Essência transcendente da personalidade. Nesta concepção o samadhi é pré-requisito para que posteriormente o praticante atinja uma condição onde sua mente conscientiza-se e transcende as estruturas de concepções geradoras de sofrimento. Dessa forma atinge-se o Kaivalyam: "a vivência de integração com tudo e destruição de todo o apego a diferenciação.” (BARBOSA, 2006).

No Yoga de Patanjalim a concepção de unidade corpo-mente se expressa na medida em que se admite que, através de exercícios respiratórios e a assunção de 
determinadas posturas físicas por determinado tempo, o praticante é capaz de desencadear estados de quietude mental com potencial transformador de sua apreensão e relação com o mundo, capaz de atingir um tipo de transcendência do mesmo.

Buscando demonstrar quão amplas são as definições sobre corpo e mente em diferentes tradições, observamos a descrição tupi guarani-tubuguaçu do corpo-som-doser (JECUPÉ, 1998). O espírito é entendido como música, é a fala sagrada que é soprada através do corpo. Os guaranis distinguem sete pontos no corpo e para cada um atribuem tom sonoro, exceto para um dos centros localizado no topo da cabeça, onde entendem que vibra o som do silêncio. Em sua cosmovisão, suas canções servem para provocar uma espécie de sintonia destes centros para que seus corpos ressonem com frequências da Terra e em harmonia com o Sol. Cada som ao ser vibrado no corpo estimula uma aspecto psicológico do ser, como: concentração, bem-estar emocional, criatividade, intuição entre outras.

Para a etnia tupi guarani-tubuguaçu é como se o universo fosse música, é som para além de uma concepção musical, é energia em movimento, é vibração. Nós, através de suas tecnologias de ser, poderíamos nos unir ao ritmo cósmico e tocar junto com ele o que representa uma existência humana em equilíbrio com o cosmo-sistema. E aqui, mais uma vez, vemos o corpo sendo utilizado, através da dança e do canto, como parte de um processo que favorece saúde corpórea e psicológica.

Recentemente estivemos em viagem com Álvaro Tukano. Álvaro é o atual diretor do Memorial dos Povos Indígenas de Brasília, liderança da etnia Tukano na luta dentro do movimento indígena pelos direitos dos povos tradicionais. Perguntamos como seu povo concebia corpo e mente, ele respondeu que para os Tukanos o corpo é alma, se a alma não está bem o corpo não está bem, e se o corpo não está bem a alma não está bem. Foi interessante percebermos a simultaneidade da interação, pois ele não a colocou em uma lógica de causalidade.

Em nenhum momento encontramos, apesar de ligeiras semelhanças principalmente entre as tradições antigas, uma concepção de corpo e mente que seja a mesma para todas as culturas. Todas se desenvolvem a partir de seus próprios pontos de vista, de sua própria percepção e de sua subjetividade. Os indivíduos nas diversas culturas, são corporeidades que criam representações, são corpos-mentes produzindo concepções de si. 
A partir de Zigmund Freud e Breuer (1895), em seus estudos sobre a histeria, percebemos um marco no pensamento ocidental. Quando Freud conclui que comportamentos típicos da histeria, como o tique nervoso, teriam relações com aspectos psicológicos, sendo talvez um dos primeiros autores da modernidade a expressar e intuir sobre tal interação.

A ideia da interação corpo-mente ganha força no ocidente através das ideias de Wilhelm Reich (1897-1957). O discípulo de Zigmund Freud, Reich foi considerado o pai das psicoterapias corporais. Com sua teoria das couraças musculares construiu a ideia de que conflitos enfrentados pela pessoa são traduzidos à musculatura da mesma enrijecendo-a e removendo a vitalidade em função ausência de passagem da energia vital, que Reich conceituou como orgone.

Segundo Reich (1978), o orgone é uma força vital existente em todo o universo, no organismo humano é responsável por trazer vitalidade ao corpo e teria também efeitos psicológicos. O conceito elaborado por Reich não é algo novo, porém encontrou resistência no meio científico por seu caráter místico e de difícil comprovação empírica.

Este conceito se assemelha muito ao conceito de prana, desenvolvido pelos hindus, e o de chi, desenvolvido pela medicina chinesa. Ambos correspondem a um tipo de energia vital, que quando se encontram em abundância no organismo contribuem para gerar um bem-estar físico, psicológico e espiritual. As teorias de Reich influenciam uma série de práticas psicoterápicas desenvolvidas no ocidente com a finalidade de propiciar autoconhecimento e integração do indivíduo.

O pensador francês Maurice Merleau Ponty (1908-1961) se aprofunda em uma busca pela compreensão do fenômeno da percepção. Tem sido utilizado como grande referência e marco em trabalhos que se referem à corporeidade dentro do campo da educação física. Ao distinguir sensação e percepção, porém sem dividi-las, Merleau Ponty critica a ciência cartesiana, pois a ciência não seria capaz de captar a pura verdade e sim apenas produzir mais um ponto de vista.

Merleau-Ponty (1999) traz de volta o tema da subjetividade ao expressar que o ato de perceber está em uma íntima relação com o sentido produzido pelo ser-nomundo. É justamente por isso que podemos notar que neste tópico apresentamos várias 
percepções sobre o corpo e mente, de cada compreensão resultam diferentes formas de se relacionar com os mesmos.

Um exemplo, quando trazemos ao ocidente a medicina chinesa estamos em busca de uma forma alternativa, em relação a oportunizada pela medicina ocidental, de relacionar-se com a saúde. Essa outra percepção, da relação corpo e mente, dos chineses permite diferentes interações que podem ter resultados benéficos e as vezes até mais eficazes para as pessoas que com ela se tratam.

Outro autor que nos chamou atenção, sobre o que também consideramos serem indicadores de uma relação entre corpo e mente, foi Vygotsky (2009). Vygotsky fala sobre a dupla expressão do sentimento, onde afirma que para todo sentimento ou emoção que se manifesta surgem imagens mentais correspondentes. $\mathrm{O}$ mesmo acontece quando ao imaginarmos algo, emergem sentimentos relacionados a imagem que temos em mente.

A emoção constitui-se de sensações que se manifestam no corpo. É comum dizermos que estamos com borboletas na barriga para expressar o sentimento de estarmos ansiosos com algum prova que será decisiva. Podemos expressar um nó na garganta quando em alguma situação nos emocionamos fortemente ao ponto de não conseguirmos nos expressar através das palavras. Toda emoção tem relação com aquilo que transita em nossos pensamentos e simultaneamente informam ao corpo sensações.

Nos parece simples dizer que os pensamentos se expressam em emoções e que este processo se expressa na estrutura do corpo, chamamos este processo de somatização. Mas é difícil concebermos o contrário (DYCHTWALD, 1984), que a estrutura corpórea participa do pensamento e de nossa constituição.

O pesquisador americano Ken Dychtwald (1984) debruçou-se sobre diversos workshops de psicoterapia corporal que aconteciam na California durante os anos setenta. Para definir as relações entre corpo e mente usou o termo feedback, o que significou que estes dois polos estão em contínua interação onde corpo transcreve informações na mente e mente transcreve informações no corpo.

Então poderíamos nos perguntar, qual perspectiva é a real? Podemos dizer que todas são realidades, e para cada realidade concebida existe uma forma de ser no mundo 
que se desdobra em ação política. Mas, seja qual for a perspectiva, as ações desencadeadas por ela reverberarão indefinidamente pela teia da vida afetando-a.

O xeque-mate do pensamento ecológico nos encurrala quando nos vemos na situação onde se faz necessário a emergência de uma outra visão. Uma outra percepção que nos permita uma relação solidária entre seres os humanos e o planeta Terra. Do contrário, e pior que estarmos fadados a extinção como defendem alguns ambientalistas, damos continuidade a uma existência que se sustenta em uma visão onde o sofrimento de muitos - não apenas humanos - é perpetuado para que haja o benefício de poucos.

Serge Moscovici (1975) nos diz sobre as inúmeras representações que os seres humanos utilizaram para distanciar-se de sua condição de natureza, isso através da ideia de que possuem cultura, linguagem e autoconsciência. Foram construídos uma série de argumentos para garantir uma diferenciação e soberania do seres humanos em relação à natureza, o que teria nos levado a construção de uma sociedade que está contra a natureza.

Observamos uma diferença básica entre as concepções de corpo e mente na modernidade ocidental, na antiguidade oriental e nos povos tribais. Na concepção dos dois últimos coloca-se o ser humano como esta unidade corpo-mente integrada ao mundo. A modernidade ocidental entende a unidade corpo-mente como máquina que possuí um hardware (corpo) e software (mente) totalmente independentes, separada do mundo e soberana em relação a ele.

Para a medicina ocidental, por exemplo, este tipo de concepção pode orientar um tratamento que incide apenas sob aspectos fisiológicos, jamais permitindo ao médico atingir uma compreensão integral do problema. Não permitindo que o mesmo investigue a pessoa com mais profundidade baseado em suas crenças, motivações, história de vida e emoções que permeiam seus hábitos (GONZÁLEZ REY, 2011).

Retornemos ao pensador francês Merleau-Ponty (1999), que ao refletir sobre o fenômeno da percepção, caminha em direção à compreensão de como o mundo é percebido sensorialmente e simultaneamente subjetivamente. Sua contribuição é excepcional no sentido de nos desvelar caminhos que incitam a pensar com cuidado a questão do que é o real e as realidades, pois consciência e mundo não estão separados. 
A corporeidade em Merleau-Ponty não apenas rompe com a perspectiva que cinde corpo e mente, rompe também com a distinção entre observador e observado, sujeito e objeto e consciência e mundo. Dando novamente à existência um caráter orgânico, relacional e finalmente abrindo a possibilidade de remoção do véu que torna estanque nosso olhar.

É a partir de Merleau-Ponty que temos uma sólida produção teórica que academicamente nos autoriza a abrir nossos olhos para diferentes produções culturais acerca da unidade corpo-mente entre outros saberes, pois através de seus argumentos a supremacia da ciência cartesiana fora abalada.

Merleau-Ponty tem sido utilizado como um marco dentro do campo da Corporeidade, sendo ele mesmo quem cunhou o termo. Para Merleau-Ponty (1999) o corpo é a estrutura aberta, que permitirá atribuirmos sentido ao mundo, e é através desses sentidos que conheceremos o próprio corpo e o mundo.

Ao entrarmos em contato com Merleau-Ponty, nos impressionamos com os pontos de contato que enxergamos entre a teoria da subjetividade e a fenomenologia da percepção, pois o ato de percepção não é apenas uma questão fisiológica. $\mathrm{O}$ ato de perceber é subjetivo, está permeado pela subjetividade do observador. O sentir não é puro sentir, não existe a pura sensação, toda sensação simultaneamente vem acompanhada de uma impressão.

A subjetividade associa-se a estrutura fisiológica do olho, permitindo que fechemos o foco para enxergamos um objeto destacando-o de um fundo. $\mathrm{O}$ delineamento que damos às coisas quando as olhamos tem íntima conexão com nossa constituição, dentro de uma cultura e em um determinado tempo histórico.

A percepção é acompanhada pela subjetividade. A subjetividade em seu desenvolvimento constituirá a maneira como nós sentimos/percebemos o mundo, dará um colorido às sensações, interferindo em nossas escolhas, abrindo ou restringindo nossas possibilidades de acesso a algo.

Outro ponto interessante na obra de Merleau-Ponty é sobre a pré-reflexividade que existe na ação. O aprendido encarna-se no corpo (GONÇALVES, 1994). Ao dirigirmos um carro nós não estamos conscientes de todos os movimentos que precisamos realizar para dirigir. $\mathrm{O}$ corpo integra a si mesmo uma rede de sentidos que 
constituem o ato de dirigir e sem que haja um movimento consciente, nós dirigimos, é como se estivéssemos em um piloto automático. Isso não é problemático quando se trata de dirigir, mas é possível que outras coisas que tenhamos aprendido nos impeçam, automaticamente, de ver e ser algo a partir de outra perspectiva.

Quando obrigamos nossos alunos a permanecerem com seus corpos sentados, imóveis e em silêncio, diante do professor que detém o conhecimento, não estaríamos reforçando uma postura de passividade diante da vida? A constituição de sujeitos é extremamente complexa e não é possível afirmar que dentro deste contexto de passividade não exista a possibilidade da emergência de sujeitos criativos. Pelo contrário, quase todos os sujeitos criativos estudados até hoje permaneceram a maior parte do tempo sentados disciplinadamente. Nos questionamos se um outro contexto, onde se reconheça a participação do corpo no processo de aprendizagem, seria favorável emergência de recursos subjetivos associados à criatividade.

Merleau-Ponty tem sido considerado como um marco porque nos traz um novo olhar sobre o corpo e sobre o mundo constituído de forma relacional. Um novo olhar sobre como o que é aprendido se enraíza corporalmente e como o corpo interage com realidades a partir do aprendido e mais uma vez aprende com ela num infinito ciclo.

Educar não se restringe mais a um ato reflexivo ou de operações puramente intelectuais. Aprender é encarnar uma realidade em si, realidade que, dependendo da forma como se configura, contribui tanto para limitar o indivíduo como também para auxiliá-lo a ampliar as possibilidades de atuação como sujeito.

Nesta perspectiva, nos contextos educativos, a presença do corpo vai além da prática desportiva que predomina nas escolas, desdobra-se para além das aulas de educação física. Torna-se algo ao qual devemos dar séria atenção, uma responsabilidade de todo educador, independente de sua área de conhecimento, de conceber os seres em processo educativo por meio de sua complexidade.

Ao concebermos novamente a integração existente entre corpo e mente, como educadores, temos a oportunidade de reconhecer que os corpos com quem nos relacionamos, que estão diante de nós não são um amontoado de carne, ossos e processos bioquímico. Eles possuem caráter sensível, emocionam-se, possuem histórias encarnadas em seus corpos. Partindo deste lugar temos novas lentes para interpretar, 
temos novos desafios para desenvolvermos processos educativos que favoreçam o processo rumarmos em direção a nossa inteireza (SANTOS NETO, 2006).

\subsection{Corpo e Criatividade: Refletindo sobre as contribuições do corpo-mente} no desenvolvimento da criatividade, numa perspectiva da subjetividade.

Ao investigarmos os trabalhos de psicoterapeutas corporais desenvolvidos no ocidente (DYTCHWALD, 1984, LOWEN, 1970, PIERRAKOS, 1987) e textos acadêmicos sobre práticas meditativas desenvolvidas no oriente (ELIADE, 1996; FEUERSTEIN,1998; GOLEMAN,1997; GROF, 1994) percebemos que ambos narram a emergência de aspectos benéficos aos praticantes. Estes aspectos em muito se assemelham aos elementos participantes das configurações criativas encontradas nas pesquisas desenvolvidas por Mitjáns Martinez (1997, 2008).

Reconhecemos que as correntes que concebem esta integração entre corpo e mente são muitas. Elas merecem um trabalho sério que consiga rastreá-las para encontrarmos o momento histórico que emergem, suas regularidades, diferenças, possibilidades e limitações, entretanto este não é intento deste trabalho.

Uma série de psicoterapias corporais se desenvolveram no ocidente dês de Wilhelm Reich (1978). Alexander Lowen (1970) e John Pierrakos (1987) foram alunos de Reich. Considerados os primeiros neo-reichianos, desenvolveram linhas psicoterápicas como a Bioenergética e a Core Energetics, ambas utilizam práticas corporais como parte de seu processo terapêutico. Entre outras aproximações também achamos válido citar os nomes do russo Moshe Feldenkrais (1977) e sua obra magna Consciência pelo Movimento. E a recente prática terapêutica Sistema Rio Aberto da argentina Maria Adela Palcos (BARROS, 2008) e a Biodanza de Rolando Toro (2008).

Uma característica geral encontrada por nós nos trabalhos que tem contribuído para a construção do campo de estudos da relação corpo-mente, principalmente nas correntes neo-reichianas (LOWEN, 1970; PIERRAKOS, 1987) e na obra de Ken Dychtwald (1984) é a relação personalidade e corpo-mente. Os trabalhos são permeados pela compreensão de que a pessoa, ao longo de sua vida, no enfrentamento de situações cotidianas, na maneira como reage, vai imprimindo informações em seu corpo e mente e vai constituindo sua personalidade. 
$\mathrm{Na}$ introdução do livro 'O Corpomente' de John Dychtwald (1984), há um momento em que relata estar nu diante de Jonh Pierrakos em um workshop na California. Em instantes, Pierrakos ao observar o corpo de Dychtwald traz a tona uma série de informações sobre sua história. Fala sobre a maneira como Dychtwald relacionou-se com figuras como seu pai, sua mãe, como se relaciona com as pessoas em geral e citou também aspectos íntimos de sua personalidade. Pierrakos diz fazer toda esta leitura apenas a partir do corpo de Dytchwald e lhe garantiu que para realizá-la apenas leu o que estava impresso em seu corpo físico, em momento algum havia usado percepção extra-sensorial.

O intrigante nessas abordagens é que o corpo também participa da constituição da personalidade, não acontecendo um processo linear de influência do psicológico sobre o corpo e nem o contrário. O corpo e a personalidade estariam num contínuo movimento que se influencia reciprocamente e simultaneamente (DYCHTWALD, 1984).

Lowen (1970) hipotetiza como contratilidades musculares na área da face poderiam interferir na maneira como a pessoa sente e interpreta o próprio movimento. Neste caso Lowen faz a referência ao desconforto que a pessoa sente ao realizar o ato de beijar, condição que poderia ser superada caso os movimentos se tornassem adequados. Adequados, segundo Lowen, tem uma relação com a devolução da consciência e vitalidade ao próprio corpo.

O trecho também sugere que a autoconfiança, um dos aspectos que é frequentemente associado à criatividade, pode emergir como resultado deste processo de tomada de consciência. É neste sentido que, ao compreendermos a criatividade em sua complexidade numa íntima relação com a personalidade, percebemos que os estudos desenvolvidos pelas linhas psicoterápicas corporais estão em busca da transformação da personalidade. Estão buscando facilitar a emergência de recursos subjetivos que favoreçam o bem-estar integral da pessoa.

É importante ressaltar que a epistemologia qualitativa não consegue verificar como este processo de transformação do sujeito acontece de forma absoluta. Nem pode atestar a veracidade dos modelos teóricos elaborados por essas linhas psicoterápicas ou de tradições de sabedoria. Este assunto é tratado por elas mesmas, por seus sistemas de inteligibilidade e concepção de ser humano. A epistemologia qualitativa nos permite 
gerar modelos de teóricos, para compreendermos o processo de movimentação da subjetividade dos indivíduos que participam de tais processos terapêuticos ou práticas meditativas.

As tradições sapienciais do oriente como a dos yogis, dos budistas, sufis, e as diversas tradições tribais pelo planeta, desenvolveram técnicas que os conduzem a estados meditativos de consciência, ou ainda nebulosamente chamados de estados alterados de consciência (GOLEMAN, 1997, ELIADE, 1996). Dizemos nebulosamente, porque o termo ainda possui uma dimensão pejorativa dentro dos círculos de estudo da psicologia, assim como a palavra transe.

Em 10 de novembro de 2013 o Programa de Pós-Graduação em Psicologia e Cultura do Instituto de Psicologia da Universidade de Brasília realizou um mesa redonda com o nome de Hipnose, transe e subjetividade. Estavam presentes o professor Maurício Neubern, pesquisador que tem domínio sobre o campo da subjetividade e também dentro do tema da dimensão espiritual do paciente na prática da terapia, e o professor Fernando González Rey.

Neste rico momento o professor González Rey questiona-se: uma pessoa em meditação ou um praticante de karatê quando está concentrado encontra-se em um transe? Ao fazer esse questionamento Gonzalez Rey também expressa a ausência de um conceito claro que defina o que acontece dentro dessas condições.

As palavras transe e estado alterado de consciência ainda estão fortemente associadas a um estado onde o indivíduo está fora de si, sem consciência. Stanislav Grof (1994, 2000), considerado um dos pais da psicologia transpessoal, nomeou esses estados de estados holotrópicos de consciência em oposição ao que chamou de estados hilotrópicos de consciência.

Holos representa a totalidade, o estado holotrópico de consciência é um estado de consciência que se direciona ao Todo. Hilo representa as partes, é o estado em que nos encontramos na maior parte do tempo, direciona-se às partes. Preferimos chamá-los de Estados de Ser, pois nesses estados não apenas a consciência encontra-se em funcionamento diferenciado, mas todo o Ser.

Vários autores inquietos com nosso presente e futuro, que se empenham na superação do atual paradigma científico, fazem menção às tradições da antiguidade 
(CAPRA; EICHEMBERG, 1987; GOSWAMI, 2007; KEN WILBER, 1989; MORIN, 2002; SANTOS, 2010; STANISLAV GROF, 1994, 1987). Nossa hipótese é de que a visão holística apresentada por essas tradições mantenha algum tipo de relação com os Estados de Ser vivenciados pelas mesmas e pela consequente subjetividade produzida por esses povos, tanto durante como após estas experiências.

Sabe-se que tais tradições desenvolveram tecnologias não para aumentar as lentes de um microscópio externo, mas as lentes que nos permitem olhar para dentro e vivenciarmos algo inarrável e transformador. Está experiência tem sido chamada de por Stanislav Grof de consciência cósmica. Sobre esta experiência Grof (1994) diz:

Experiências de consciência cósmica têm sido descritas em muitas escrituras religiosas através da história. O importante princípio criativo tem sido conhecido por muitos nomes: Brahman, no hinduísmo; Dharmakaya, no budismo mahayana; Tao, no taoísmo; Pneuma, no misticismo cristão; Alá no sufismo; Keter, na cabala. A mensagem básica das tradições místicas é que podemos experienciar e nos conectar com o princípio, e, também, que cada um de nós, de certo modo, é o principio criativo. (p.201)

Daniel Goleman (1997) em A mente meditativa monta um quadro comparativo de diferentes práticas meditativas. Goleman percebe que todas discorrem que o praticante que atinge uma espécie de realização última dentro daquela prática é um ser completamente transformado. Sua conduta é muitas vezes explicitada como de uma afeto inabalável por todos os seres acompanhado de uma incrível faculdade de conhecer a complexidade da insatisfação humana, superá-la e auxiliar os outros em sua superação.

O mistério que ainda paira e que começa a ser discutido por Grof $(1994,2000)$ não é sobre a consistência material desta experiência. E sim como o praticante de tais psicoterapias ou meditações subjetiva esses estados de ser. Podemos até dizer que a experiência é inarrável, mas é vivenciada, subjetivada e impacta o praticante. Mas de que forma impacta?

De acordo com o que estamos compreendendo, a subjetividade em seu caráter ontológico, não é sinônimo de consciência. A pessoa pode encontrar-se em um determinado estado de consciência, como o de completamente alerta (sampajañña, no budismo antigo), focado em um objeto de meditação como a respiração. No entanto, quando o praticante abandona este instante e retorna a um estado ordinário, pode 
emocionar-se em relação a um conteúdo ou experiência que lhe ocorreu em estado de meditação. Pode produzir subjetivamente acerca do experienciado tanto consciente como inconscientemente.

A questão chave é que através da própria corporeidade, em associação com específicas práticas, tornamos possível ao seres humanos a faculdade de acessar outros estados de ser ou de consciência. Estes estados inclusive possuem um correlato com diferentes frequências cerebrais (HORAN 2009), produzindo uma experiência do presente momento radicalmente diferente do percebido através do estado de vigília.

A alteração na atividade das frequências cerebrais durante a prática de meditação tem sido estudado e comprovado em pesquisas que se utilizam do aparelho de eletroencefalograma para checar a atividade cerebral de um praticante de meditação (HORAN, 2009). Esta mudança de Estado de Ser oportuniza momentos de singular produção subjetiva ainda pouco investigados.

Estes estados são pouco conhecidos por nossa ciência, mas tradições do oriente possuem tratados onde classificam, até mesmo hiearquizam, diferentes estados de ser. $\mathrm{O}$ guru Osho exemplifica isto em seu livro Orange (2013). Osho discorre sobre o estado de consciência que as pessoas que praticam corrida acessam, chamado de turiya: “...um momento vem em que o corredor desaparece e só há o correr. O corpo, a mente e a alma começam a funcionar juntos: de repente, um orgasmo interior acontece." (RAJNEESH, 2013).

Dentro da psicologia humanista Abraham Maslow chegou a dar atenção a tais experiências, as quais chamou de experiências de pico. Maslow chegou a fazer uma relação entre a constituição de sujeitos auto-atualizadores e a frequência de experiências de pico na vida da pessoa.

O filósofo Ken Wilber (2006) no livro Espiritualidade Integral, dedicou-se a categorizar diferentes estados de consciência. Wilber delineou dois conceitos: os estados e os estágios de consciência.

Os estados referem-se a uma série de estados que estão disponíveis para serem acessados pela pessoa em meditação. A entrada e permanência dentro de um estado, tem implicações na constituição de um estágio de consciência. As produções subjetivas acerca do que é experienciado em determinado estado de consciência ganham certa 
estabilidade configurando um estágio de consciência. A constituição dos estágios de consciência a partir das experiências de outros estados de consciência são integrados pelo indivíduo de diferentes formas, dependendo de sua história de vida, de sua configuração subjetiva.

Um exemplo sobre isso, a possibilidade de uma pessoa experienciar um Estado de Ser como o de consciência cósmica, ter recursos subjetivos para dar inteligibilidade a esta experiência e poder vivenciá-la de uma maneira agradável. Outra pessoa por não ter desenvolvido esses esquemas respresentativos ou até mesmo sentidos subjetivos que lhe garantam familiaridade com estes estados. Dessa forma, talvez ao viverem esta experiência poderiam senti-la como algo desagradável e aterrorizante.

Em ponto de contato com a teoria da subjetividade, os estágios que Wilber fala seriam os impactos que a experiência em outros Estados de Ser teriam na subjetividade, transformando as configurações subjetivas. O ponto de referência, utilizado por Wilber (2003), para criar sua hierarquia dos estágios de consciência e desenvolvimento humano está relacionado ao desenvolvimento da compassividade em relação aos diversos outros.

Apesar de demonstrar certa complexidade, a representação de estados/estágios de consciência de Ken Wilber ainda nos parece redutora, diante das infinitas possibilidades que podem tomar as configurações subjetivas, em função da produção singular do indivíduo em sua interação com a experiência.

No momento em que, por algum motivo, a consciência se encontra num estado não-ordinário, o indivíduo pode produzir novos sentidos subjetivos diante deste instante onde experiência a si mesmo e o mundo de forma diferenciada.

Estes estados estão longe de ser algo surreal ou distantes de nossa realidade. Nós os realizamos durante toda vida, por exemplo quando nos concentramos para ler um texto de difícil acesso ou através de exercícios físicos. A questão é, a ciência ocidental não possui um corpo de conhecimento que nos possibilite perceber isso de tal forma, pela simples razão e limitação que a ciência moderna não concebe como científico a investigação da interioridade pela interioridade, um Eu que investiga a Si Mesmo, e que neste processo produz conhecimento ou ciência (WILBER, 2001). A ausência de um conhecimento em nossa ciência moderna, que discorra sobre isto e a sua potência, não 
nos permite tomarmos consciência do que fazemos e nem tanto como fazê-lo intencionalmente de forma autônoma e apropriada, intensificando seus efeitos.

Um universo de produção subjetiva pode emergir sempre que houver uma experiência. Sempre que o indivíduo se emocionar diante de algo que experiência na relação corpo-mente. Por exemplo, uma pessoa que decide permanecer trinta minutos de olhos vedados, restringindo toda sua atenção ao tato e ser conduzida por um lugar desconhecido. A subjetividade é produzida pelo indivíduo que explora sua corporeidade, principalmente se neste momento ele for instruído a estar alerta para o que lhe surge a nível de emoções, memórias, pensamentos, sentimentos e os observe com atenção. Em síntese observar o que lhe vem a "cabeça" enquanto observa seus sentidos entrarem em contato com seus objetos.

Não é possível garantirmos que os estudantes que participam do projeto efetivamente acessem estados meditativos. Isso não pode ser feito tanto porque os participantes não possuem um referencial que os permita reconhecer tais estados e também porque não temos um referencial teórico científico que nos permita identificálos.

Mas acessando ou não esses estados, este é um dos objetivos da dimensão prática do curso e do projeto de extensão que apresentaremos a seguir. Parte desta cosmovisão mística e recente produção científica são as fontes que alimentam a subjetividade do idealizador do projeto e consecutivamente as dimensões prática e teórica do curso.

Durante estas experiências também produzimos subjetivamente tornando-se este um dos objetivos da nossa pesquisa, descobrir como a subjetividade movimenta-se nestas experiências onde indivíduos são convidados e orientados a experimentar e observar atentamente a unidade corpo-mente. Será que estas experiências contribuem para a emergência recursos subjetivos associados à criatividade, como auto-confiança, aceitação de si e desinibição?

O curso Corporeidade e do projeto de extensão Movi-mente tem por objetivo: a consciência corporal; a meditação, através de técnicas de meditação dinâmica; exercícios direcionados a ampliação de nossa consciência corporal; e a vivência de integração entre corpo/mente/espírito; natureza/cultura/consciência. Buscaremos 
compreender se na relação dos alunos com este espaço social, onde a proposta é a experimentação de sua corporeidade, ocorre a emergência de processos subjetivos que possam ser associados à criatividade.

\subsection{Movi-mente: Meditação através do movimento. Onde o Kaos Criativo Dança.}

O Movi-mente ${ }^{2}$ é um projeto de extensão desenvolvido na Faculdade de Educação Física da Universidade de Brasília (FEF/UnB). O professor Marcelo de Brito $^{3}$, mais conhecido por seu nome de iniciação espiritual Dhyan Kapish. Graduou-se em Educação Física pela UnB, foi influenciado por Paulo Freire, Edgar Morin, Varela, Maturana, Fritjof Capra, Amit Goswami e Ken Wilber. Ao longo de sua história também teve contato com meditação de diversas linhas. Teve a oportunidade de conhecer diversas terapias psicocorporais modernas, é sem dúvidas um indivíduo que possui a espiritualidade como um dos pilares de sua existência. É fortemente influenciado pelo xamanismo de Carlos Castanheda, tradições místicas brasileiras, pelo místico George Gurdjieff e o guru Osho.

Não é nada fácil falar de Dhyan Kapish, mas tivemos a oportunidade de passar dois anos ao lado deste ser que inspira aqueles que com ele convivem. Este senhor tem disposição de um jovem e com humildade e brincadeira expressa uma sabedoria anciã. Imaginamos que, por seu trabalho, no mínimo deve gerar em seu colegas de faculdade algum tipo de estranhamento, mas dificilmente indiferença. Sua alegria é contagiante e sua paciência para lidar com problemas do cotidiano nos faz perceber o quanto a impermanência é para ele um fato. Bastava perceber sua reação a alguma coisa inusitada que lhe acontecesse durante a semana ou nas imersões, com alegria no olhar ele se referia a isto como uma provação divina, como se as vicissitudes que nos abarcam cotidianamente fossem sagrados presentes para nos tornar melhores.

Partilhamos com Kapish o mesmo fascínio pela meditação, durante esse período tivemos o sentimento de estarmos trabalhando juntos naquilo que acreditamos. Auxiliar a emergência no espaço acadêmico de investigações e experiências que ampliem nossa

\footnotetext{
${ }^{2}$ Para maiores informações sobre a trajetória de Marcelo de Brito e sobre o Movi-mente, sugerimos a leitura de sua tese de doutorado disponível na internet: A construção do sentimento de unidade: desdobramentos de uma abordagem corporal atípica. Universidade Trás-os-Montes e Alto Douro, Vila Real, 2013. O projeto oficial do Movi-mente se encontra no ANEXO II deste trabalho.

${ }^{3}$ O professor Marcelo de Brito autorizou a utilização de seu nome oficial neste trabalho.
} 
compreensão sobre o que seja ser/existir. Contribuir para o desenvolvimento integral dos seres humanos e para bem estar planetário. Estar em sua presença é estar constantemente observando a si mesmo, investigando a vida e seus mistérios. Nossas palavras chave eram: meditação, presença, consciência, transcendência, corporeidade, alegria e sincronicidade.

Kapish iniciou o Movi-mente no final dos anos noventa no Centro Olímpico da UnB. Dificilmente algum participante conseguiria explicar pontualmente o que acontece na Sala do de Dança do Centro Olímpico religiosamente toda segunda-feira das $19 \mathrm{~h} 30$ às $22 \mathrm{~h}$. Já observamos várias pessoas tentarem definir o que é o Movi-mente para outras pessoas. Quando perguntadas, geralmente fazem uma pausa representando reflexão e a resposta em seguida, que abre o início da explicação, sempre expressa que é difícil dizer o que é o Movi-mente.

O espaço é frequentado basicamente por alunos de todas as graduações da UnB, ex-alunos da UnB, mas também é aberto a comunidade. Como o nome diz, Movimento e Mente. Não há como dizer o que o Movi-mente é, porque ele não é, ele está sendo. Se tentássemos dizer o que ele é, nós teríamos de torná-lo extático, então deixaria de estar em movimento, deixaria de estar sendo. Um de seus objetivos é permitir que os participantes percebam que eles também estão sendo, sendo parte de algo maior, são o Cosmo e a complexidade da Vida em movimento.

Entendemos o Movi-mente como uma prática pedagógica transdisciplinar e transpessoal que sintetiza uma nova tecnologia do $\mathrm{ser}^{4}$. É baseada nas tecnologias do ser de tradições orientais, xamânicas e tribais. Na modernidade suas práticas nutrem-se da educação física e da psicoterapia corporal. No campo teórico é aportado pela fenomenologia de Merleau Ponty (1999), no pensamento complexo de Edgar Morin (2002), das alternativas interpretações da Física Quântica de Goswami (2007) e Capra (1987), da Teoria dos Campos Morfogenéticos de Rupert Sheldrake (1996). A finalidade é conduzir os praticantes a uma ampla consciência corporal, confiando na potencialidade da experiência meditativa e em sua ação benéfica para aqueles que a experienciam.

\footnotetext{
${ }^{4} \mathrm{O}$ termo tecnologias do ser é utilizado por Stanislav Grof em seu livro A psicologia do Futuro (2000), se refere a todas as práticas e técnicas que se desenvolveram com objetivo de conduzir a pessoa a outro Estado de Ser, como as diversas técnicas de yoga, meditações budistas de concentração em um determinado ponto do corpo ou utilização de instrumentos musicais e sons evocativos usados em rituais xamanicos com essa finalidade.
} 
De acordo com Kapish as motrivivências, quando conduzidas por ele, apesar de possuírem princípios e fundamentação teórica, nunca são previamente elaboradas. Pois precisam ser a emergência da criatividade que acontece no momento em que nos tornamos presentes no aqui e agora, na criativa vacuidade de onde tudo surge. As práticas emergem no momento presente, pois elas necessariamente precisam ser uma expressão criativa e intuitiva. Percebemos que são uma síntese entre aquilo que já é conhecido por ele com aquilo que sente que deve ser trabalhado no momento presente. Seu fundamento é a busca por atender aquilo que percebe como sendo a necessidade dos participantes naquele instante.

Segundo Kapish (BRITO, 2013) os princípios que regem as Motrivivências são:

1. O anel tetralógico, interrelacionando desordem, organização e ordem de onde surgiu a ideia do Kaos Criativo que constitui o elemento dinamizador; a forma de desestabilizar o status quo (individual e coletivo).

2. O jogo, manifestação holística por natureza, através do qual podemos explorar os elementos culturais de forma plural e dialética dos opostos complementares dinamizando a essência lúdica.

3. Os chakras que representam portais para a conexão interiorexterior onde, explorando suas peculiaridades, podemos entrelaçar a complexidade multidimensional do indivíduo.

4. Os campos morfogenéticos, que constituem o contexto relacional ou a esfera de conexões/interações entre os seres, o meio e a informação. (p.91)

Essas experiências são orientadas com a intenção de propiciar aos participantes uma a possibilidade de vivenciarem a si mesmos como parte integrante do todo e simultaneamente contendo em si o todo. A busca é por facilitar a emergência de um sentimento de Unidade com profundas implicações em nossos modos de ser (BRITO, 2013).

Estamos falando da possibilidade de vivenciarmos corporalmente o que está sendo teorizado pela física quântica (CAPRA; EICHEMBERG, 1987; GOSWAMI, 2007), expressado pelo paradigma da complexidade (MORIN, 2002) e o que é preconizado pelas tradições antigas a mais de 3.000 anos. O psiquiatra Stanislav Grof (1994) citou uma experiência, semelhante a esta, de vivência de consciência cósmica:

Quando experienciamos identificação com a consciência cósmica temos a sensação de envolver a totalidade da existência dentro de nós, e de compreender a realidade subjacente a todas as realidades. 
Sentimos, de maneira profunda, estar em conexão com o supremo e fundamental princípio de todo Ser. (p.201/202)

Concluímos parcialmente que um dos objetivos ou desdobramentos que o Movimente tem mantém íntimas relações com experiências semelhantes a narrada no trecho acima. Falando-se em Estados de Ser, o que difere um grande mestre de meditação de um neófito, é sua proficiência em entrar e permanecer em um outro Estado de Ser como o da consciência cósmica. Os neófitos, através das práticas, são arrebatados momentaneamente para um estado de ser e brevemente retornam.

Um dos princípios fundamentais do projeto de extensão desenvolvido por Marcelo de Brito ${ }^{5}$ é o Kaos Criativo. Segundo Brito (2013) a palavra Kaos escrita com a letra ' $k$ ', foi tomada do compositor brasileiro Jorge Mautner para expressar o Caos, que é a desequilibração conscientemente promovida para dinamizar a criatividade.

Brito apoia-se no princípio de auto-reorganização como apresentado por Morin (2002), e que tem uma de suas bases no pensamento do químico Ilya Prigogine (2002). Este princípio concebe que a natureza possui um mecanismo auto-regulativo que opera sempre que um "desequilíbrio" surge. Portanto as motrivivências sempre culminam em um ponto caótico, que é deliberadamente organizado, para que os participantes possam a partir do Caos se reorganizar. Sobre seu intuito com o Movi-mente Brito diz (2013):

\begin{abstract}
O ser inteiro deveria, pois, ser digno de sincera busca. Neste sentido, construímos uma abordagem de trabalho corporal que busca o desenvolvimento integrado das dimensões humanas e cujo objetivo é ampliar a consciência da unidade. Não é, entretanto, o desígnio de forjar budas ou seres iluminados que nos move. O que se pretende é simplesmente encontrar maneiras de nos integrarmos, nos conhecermos e vivermos melhor, em harmonia com a natureza pessoal e global. (p.103)
\end{abstract}

Outro aspecto importante sobre este espaço é a concepção de Corpo em que nele podemos encontrar. O corpo-mente neste curso é destituído de uma verdade absoluta, ele é transformado em um incógnita, sua obviedade é removida.

A corporeidade no curso, a partir da apresentação do conceito de percepção de Merleau-Ponty (1999), que fragiliza o conceito de verdade objetiva e consecutivamente as bases da ciência moderna, ganha uma perspectiva multicultural.

\footnotetext{
${ }^{5}$ Professor Dhyan Kapish idealizador do Movi-mente, quando for citado a partir de seu trabalho de doutorado será usado o nome que utiliza no contexto acadêmico.
} 
Durante o curso o próprio professor insiste em não fechar completamente um conceito de corporeidade. Ao longo do semestre várias percepções criadas por diferentes perspectivas, de origem acadêmicas e não-acadêmicas, vão sendo disponibilizadas, confrontadas e discutidas abertamente.

As perspectivas consideradas não-acadêmicas são essencialmente as perspectivas místicas de sabedoria antiga, isto não é feito sem estar aportado por autores, que apesar da resistência, são considerados científicos. Autores frequentemente citados neste espaço são Fritjof Capra e Amit Goswami. Ambos tradutores da Física Quântica através das tradições de sabedoria do oriente como o budismo, hinduísmo e taoísmo.

Não sabemos qual desdobramento essa experiência pode ter para cada um. Hipotetizamos que, esse aumento da consciência da unidade e a gama de experiências que se pode viver com o próprio corpo dentro deste espaço, pode ser um marco para o indivíduo em seu desenvolvimento, chegando a causar impacto significativo na própria personalidade.

Ao ser impactado suas ações podem passar a ser acompanhadas por um sentimento de solidariedade em relação à coletividade, que não mais é sentida como separada, mas como sendo a própria pessoa. Partindo desta perspectiva, ser feliz e construir a felicidade significa construir a felicidade de muitos e não mais apenas a exclusiva "felicidade" individualista.

A busca pelo desenvolvimento da pesquisa neste espaço está para além de nosso desejo por compreender o impacto de estados meditativos na subjetividade. Se dá também pelo envolvimento prévio que tivemos com o mesmo e pelos questionamentos que foram levantados a partir dos inúmeros relatos de pessoas, que acreditavam ter vivido uma verdadeira transformação durante a permanência no projeto.

Ao olharmos, sob o prisma da teoria da subjetividade, o estado meditativo ou as práticas do Movi-mente não teriam sobre o indivíduo um efeito direto que configure sua subjetividade. O indivíduo na relação com este espaço, as práticas e as diversas experiências que nele emergem poderia produzir sentidos subjetivos, ter sua subjetividade reconfigurada por este dialético processo. 
As transformações expressadas pelas pessoas participantes do Movi-mente, apesar de acontecerem numa relação com práticas corporais para alçar experiências, são de ordem subjetiva. O que não é surpreendente na medida em que um dos focos do curso é: perceber a existência desta unidade corpo-mente, o que se expressa quase que em conceber que a mente também é corpo. No caso das diversas percepções apresentadas no curso a mente também pode estar além do corpo humano e habitar outros corpos que estão além do corpo físico, que o transcendem e o incluem ao mesmo tempo.

Não há ênfase, na grande maioria das vezes, sobre a transformação do corpo, exceto quando se expressa no indivíduo que passou a cuidar melhor de si, chegando a ganhar expressões em sua constituição física. A emergência de um recurso subjetivo, que regula a ação de cuidar do corpo, é relatada antes de haver um relato sobre uma transformação estritamente relacionada ao aspecto físico do corpo.

Os participantes do Movi-mente, com frequencia, dizem que tornaram-se autoconfiantes, menos inibidos sobre aquilo que os outros possam pensar sobre eles, se sentem aceitando mais a si mesmos e mais abertos ao novo. Principalmente os estudantes que participam do curso Corporeidade, narram muitas vezes o quanto estavam inconscientes de atitudes mecânicas e acreditam terem se tornado menos mecânicos e mais intuitivos. Também acreditam estar mais atentos ao momento presente, desfrutando-o com uma qualidade inexistente no passado. Expressam estarem voltando a relacionar-se de forma mais afetiva com os outros e julgam-se mais abertos ao diferente e ao inusitado.

Percebemos, entre os relatos dos participantes que transitam pelo Movi-mente, processos da constituição de pessoas criativas relatadas em estudos sobre a personalidade de pessoas criativas. Desta forma encontramos na perspectiva da criatividade, como um processo complexo subjetivo, em Mitjáns Martínez ((1997, 2001, 2002, 2003, 2008, 2009) um ponto de referência para investigarmos o impacto desta abordagem da Corporeidade na subjetividade individual.

Mas como investigar isto? De que forma concluiremos que ao longo deste processo as pessoas desenvolveram ou não tais processos em alguma medida? Que instrumento utilizaremos para tentar compreender este processo? Para isso utilizaremos 
a Epistmologia Qualitativa de Fernando González Rey e a metodologia da pesquisa derivada dela que apresentaremos no próximo capítulo. 


\section{II - FUNDAMENTOS EPISTEMOLÓGICOS E METODOLÓGICOS}

\section{Caracterização da Pesquisa}

\subsection{Objetivos}

\section{Objetivo geral}

Compreender o impacto do curso Corporeirade e Expressão Corporal e do Projeto de Extensão Universitária Movi-mente na subjetividade com foco na emergência de recursos subjetivos associados à criatividade.

\section{Objetivos específicos}

- Caracterizar o curso Corporeidade e Expressão Corporal e Projeto de extensão Universitária Movi-mente nos seus aspectos técnicos, relacionais e subjetivos.

- Caracterizar formas de subjetivação da oficina por parte dos alunos.

- Identificar a emergência de recursos personológicos associados à criatividade.

\subsection{Epistemologia Qualitativa}

A Epistemologia Qualitativa nos auxilia a desenvolver novas zonas de sentido, possibilitando o desenvolvimento de um corpo de conhecimento que favorece a superação de limitações encontradas em um determinado contexto. Como por exemplo, nos auxilia a compreender uma abordagem atípica no campo da Educação Física, gerando conhecimentos que ampliem nossa faculdade de inteligir e expressar uma nova abordagem, favorecendo a abertura a processos dialógicos sobre o tema dentro do contexto acadêmico. O objetivo ampliar o reconhecimento e legitimidade de tais práticas e também de encontrar falhas e vias de superação e aprimoramento de uma determinada prática pedagógica.

A Epistemologia Qualitativa desenvolvida por González Rey (1997, 2002, 2005) será utilizada como marco epistemológico para realizarmos a pesquisa. A Epistemologia tem três princípios base:

1. O processo de produção de conhecimento como um processo construtivointerpretativo. 
A Epistemologia Qualitativa emerge como alternativa a uma ciência empirista, que atribuiu excessivo valor aos dados colhidos em campo e os caracterizou como sendo o real e não como uma realidade. Entendia-se que esses dados não passavam por uma interpretação, que era subjetiva, ou seja, que tinha sua dimensão entrelaçada ao processo histórico-cultural participante da constituição dos cientistas.

Não se percebia quão frágil é o princípio de neutralidade adotado pelos cientistas, pois a ciência não abandona a subjetividade para produzir a si mesma, a ciência é também uma produção subjetiva.

Então a Epistemologia Qualitativa devolve ao pesquisador seu caráter de sujeito. Legitima-se a liberdade para interpretar e construir, sempre em articulação entre teoria e momento empírico. Oferece-nos a possibilidade de transcendermos os "dados" quando fazemos nossas interpretações e construímos hipóteses.

No contexto de pesquisa o pesquisador interpreta os momentos de expressão dos sujeito, esta interpretação mantém estreitas relações com o marco teórico assumido, mas não se engessa nele. $O$ pesquisador em campo, tem novos insights, que não necessariamente possuem de maneira definida relações com sua base teórica prévia, por isso ele também cria, constrói novos entendimentos a partir do que observa (GONZÁLEZ REY, 2002).

2. O caráter interativo do processo de produção de conhecimento

A produção de informações no contexto de pesquisa depende da interação entre o pesquisador e os sujeitos da pesquisa e também da interação entre os sujeitos de pesquisa (GONZÁLEZ REY, 2002) . Uma das funções do pesquisador, a fim de obter as informações, é manter-se atento aos momentos para que possa inserir-se de modo a gerar reflexividade e diálogos. A obtenção de informações que irá compor seu tecido informacional depende diretamente do nível de envolvimento e expressão dos sujeitos dentro dos diálogos.

Na epistemologia qualitativa, o pesquisador é sujeito que impacta o contexto de pesquisa na medida em que para obter informações interage com os sujeitos, gerando probabilidades de transformação a partir deste contato tanto em si, como no outro. 
Apesar de compreendermos que existem várias linhas para a pesquisa-ação e não tentarmos compará-la à Epistemologia Qualitativa entendemos que o pesquisador dentro da Epistemologia Qualitativa, enquanto está em campo, sempre se encontra na condição de pesquisador-ator. Pois no momento em que pergunta, em que conversa, abre possibilidades de reflexão para o entrevistado. Isso oportuniza compreensões às quais, tanto pesquisador como pesquisado, ainda não haviam se deparado e chegando a produzir outras compreensões sobre um determinado assunto.

3. O Singular como espaço legítimo para o processo de produção de conhecimento científico.

Através deste princípio González Rey (2005) enfatiza a produção teórica do pesquisador. A legitimidade do singular como o espaço de produção do conhecimento, está garantido pelo terceiro princípio da Epistemologia Qualitativa que entende o conhecimento como uma construção-interpretativa. O aporte teórico utilizado pelo pesquisador, suas intuições e idéias, encontram-se com o sujeito de pesquisa através do estudo de caso, gerando um modelo teórico, não apenas verificando empiricamente algo previamente elaborado, mas produzindo teoricamente.

\subsection{Estudo de caso}

Tendo em vista a necessidade de imergirmos, junto ao sujeito numa busca por compreensões de suas transformações ao longo de um processo, a metodologia de estudo de caso foi utilizada para realizarmos a pesquisa. Já que a pesquisa centra-se na qualidade das informações expressadas pelos sujeitos de pesquisa e não na quantidade de indivíduos pesquisados, foi essencial que os acompanhássemos de perto numa busca por informações que tivessem valor para o desenvolvimento deste trabalho.

Os indivíduos selecionados para participar do estudo de caso foram aqueles que compreendemos estar mais envolvidos e empenhados, tanto com o curso e o Projeto como também com seu nível de expressão dentro dos instrumentos utilizados.

\subsection{Contexto de Pesquisa: $O$ curso Corporeidade e o projeto de extensão Movi-mente}


Nosso espaço de pesquisa se dividiu em dois momentos, o curso de Corporeidade e o Projeto de Extensão da Faculdade de Educação Física da Universidade de Brasília (FEF/UnB), o Movi-mente.

O curso Corporeidade e Expressão Corporal é um componente curricular optativo ofertada pela FEF. Ela acontece às segundas-feiras das $18 \mathrm{~h}$ às $21 \mathrm{~h} 45$ no Centro Olímpico da UnB. O curso se realiza em dois tempos, o primeiro que vai das $18 \mathrm{~h}$ às 19h30, é destinado às questões teóricas e discussões sobre o tema Corporeidade e no segundo momento, os alunos se dirigem ao projeto Movi-mente para a participação nas motrivivências.

O curso Corporeidade é conduzido pelo professor Marcelo Brito (Kapish) e no último semestre esteve acompanhado por dois monitores, um professor de filosofia do segundo grau e o outro era um professor de história e estudante de artes cênicas.

O professor Kapish mantém uma postura muito dinâmica dentro de sala de aula. É um professor que está sempre muito alegre e bem humorado, aparenta ser apaixonado por seu trabalho e seu entusiasmo é uma caraterística marcante. Suas aulas não possuem um caráter estritamente expositivo.

Kapish disponibiliza vídeos e textos base na internet para que os alunos reflitam e discutam durante as aulas. No momento teórico das aulas ele busca deixar os alunos à vontade, faz perguntas que estão sempre direcionadas a descobrir alguma experiência que o estudante possa ter vivido em seu cotidiano para utilizá-la como fio condutor da aula.

A partir desta experiência compartilhada por um estudante, o professor vai desdobrando explicações que estão envolvidas com o temática do dia, o texto base ou vídeo. Já observamos aulas, que a partir de discussões dos alunos, tomaram um rumo completamente diferente do que havia sido planejado.

Kapish encontra sempre uma forma de surpreender seus alunos, tirando gargalhadas e fazendo questionamentos que conduzem os alunos a um momento de reflexão sobre suas próprias experiências cotidianas. Experiências às quais provavelmente a grande maioria nunca teria se questionado. Por exemplo: "quais são suas manias de pele?" 
Enquanto Kapish falava da pele, começou a falar do que chamou de manias de pele e logo em seguida as pessoas começam a comentar suas experiências. Existem pessoas que só dormem com um lenço encostado no rosto, outros tem o hábito de ficar coçando uma determinada parte do rosto sempre que estão reflexivas. E desse ponto Kapish vai para o assunto condicionamentos, pergunta o quanto desses movimentos são realizados conscientemente em oposição a uma ação mecânica e automática.

O professor atalha de um assunto para outro. Quem não o conhece, não sabe de suas intenções e estudo por trás de tudo o que ele está fazendo, pode ficar um pouco perplexo com a descontinuidade que a aula parece ter. Em um momento estamos falando sobre a pele, na sequência estamos falando sobre consciência e condicionamentos. Aparentemente isso traz um certo desconforto para aqueles que exigem uma linearidade no desenvolvimento dos assuntos.

O desconforto e a desorganização é um dos pontos que o professor intencionalmente deseja gerar. Sua busca em orientar uma aula com certa aleatoriedade, tem íntima relação com a concepção de Caos como um princípio constituinte da ordem natural (PRIGOGINE, 2002).

No projeto de extensão encontramos o que Kapish chama de Kaos Criativo, O Kaos Criativo é a busca por conscientemente gerar um estado de confusão, confiando que a partir deste ponto a natureza segue seu destino rumo a uma nova organização.

As vezes os estudantes, por estarem comentando suas experiências, começam a conversar cochichando uns com os outros. Existe um clima leve, alegre e descontraído dentro da sala de aula. Percebemos que, ao longo do semestre, os alunos vão se soltando e o professor dificilmente chama a atenção para si mesmo.

O professor parece não se importar com as conversas paralelas que vão se constituindo. Para ele parece que o fundamental é que os estudantes envolvam-se com o tema a um nível reflexivo, mesmo que em conversas paralelas, pois depois na Sala de Dança do Centro Olímpico, logo após a discussão, uma motrivivência será conduzida mantendo relação com o que fora discutido em sala.

Os coordenadores do curso organizam um grupo no facebook onde todos os estudantes são incluídos. O grupo é utilizado para o envio de textos e de vídeos que alimentam as discussões dentro das salas de aula. No grupo do facebook o professor e 
os monitores enviam artigos científicos sobre corporeidade, vídeos sobre corporeidade ou sobre algum sentido específico como tato, visão e outros, que serão trabalhados na aula da semana.

Ao longo do semestre os alunos vão fazer uma viagem pelo corpo e o curso assume diferentes configurações de acordo com o semestre. $\mathrm{O}$ professor parece esforçar-se para que ela não se torne repetitiva. Basicamente durante o semestre os alunos percorrerão seus corpos, investigando e vivendo experiências com os cinco sentidos. Kapish introduz o sistema de chakras (centros de energia) na concepção hindu e temas como sentido, percepção, comportamento autômato, inconsciente e consciência.

Os cinco sentidos são sempre explorados numa relação com a mente. Por exemplo, para as instruções sobre um exercício sobre o tato, o professor pede aos alunos que dividam-se em duplas. Uma pessoa da dupla fica vendada e a outra guiará o colega pelo Centro Olímpico $(\mathrm{CO})$, proporcionando a seu colega diversas experiências com o tato.

A instrução do professor é para que os estudantes fiquem atentos àquilo que sentem durante a experiência, atentar-se para as emoções, para as memórias, para o sentimentos e pensamentos que emergem durante aquela experiência. Esta associação entre os sentidos e a emergência de emoções, sentimentos e pensamentos, serão ponto chave em todas as práticas. A instrução para a atenção plena é constantemente reforçada. Para aprofundamento sobre o conteúdo do curso, verificar no ANEXO I o plano de curso do curso Corporeidade e Expressão na Educação Física.

O ponto chave do momento teórico é a partilha de acontecimentos cotidianos, diálogo sobre os textos, vídeos e sobre as experiências no Movi-mente que ocorre das $19 \mathrm{~h} 30$ às 21h45. O Movi-mente nem sempre acaba às 21h45, já participamos de práticas que se prolongaram até as $23 \mathrm{~h}$, então as vezes alguns alunos do curso de corporeidade saem um pouco antes da prática acabar.

A avaliação do curso é feita através de relatos de experiências e composições relacionadas aos temas centrais do curso, todas elas devem ser escritas a mão. $\mathrm{O}$ professor é muito exigente em relação à presença, pois a centralidade do curso está em estar presente de corpo e mente. 
Às $19 \mathrm{~h} 30$ os estudantes se encaminham para a Sala de Dança. O projeto Movimente é aberto a comunidade e quando os estudantes do curso corporeidade chegam na Sala de Dança algumas pessoas já se encontram reunidas na sala esperando o início da prática. Aguardam conversando, jogando malabares, alongando e fazendo posturas de yoga ao som de alguma música cuidadosamente selecionada pelos monitores.

As músicas vão do rock'n'roll dos anos 60 e 70, passam pelos hits dos anos 80 pelo new age, pagode e axé dos anos 90. Sons de estilo étnico tribal também fazem parte desta jornada e chegam até as músicas eletrônicas que marcam a primeira década do século 21. As músicas variam de acordo com o propósito da motrivivência.

É muito difícil narrar as motrivivências, elas assumem formatos diferentes ao longo do semestre. Uma característica básica é que Kapish admite que elas não são previamente programadas, eles emergem da espontaneidade do momento presente. No começo o professor sempre traz algumas palavras, que estão em conexão com o assunto que estava se desenvolvendo dentro de sala de aula. De repente é pedido para que o grupo faça algum movimento com relação a um tópico específico desmembrado de sua fala inicial.

Observamos que existe uma forma de classificar as motrivivências. Algumas práticas que são mais lineares, uma espécie de atividade pontual, como por exemplo uma massagem no colega, que o professor pede aos alunos que realizem com tempo determinado e depois há um espaço para a partilha do vivido.

Um segundo tipo de motrivivência possui um caráter aleatório. O professor da asas a sua imaginação, vai comandando a turma incitando-a a realizar movimentos como correr, pular, sacudir, andar rápido ou devagar, movimentar-se nos planos baixos ou altos, abraçar-se, tocar-se, trabalhar em duplas, emitir sons, etc. $\mathrm{O}$ importante é que o professor, junto a isso, vai fazendo uma narrativa.

A narrativa mantém relação com as discussões que foram feitas previamente em sala de aula. Existem momentos de pausa e congelamento do som, onde perguntas são feitas, com o objetivo de gerar reflexão, inquietação e introspecção. Pode haver também a reprodução de algum tipo de áudio com uma poesia, por exemplo de Fernando Pessoa, ou mensagem de caráter filosófico e motivador. 
Comandos muito utilizados em meditações como atenção a respiração, atenção às sensações e simplesmente observe, são utilizados para lembrarem o momento no qual os estudantes devem permanecer, o momento presente. Mesmo pensando os participantes devem estar atentos ao fluxo de pensamentos e sentimentos.

Quase todas as motrivivências possuem um momento auge, onde instaura-se o Kaos Criativo (BRITO, 2013). Quando a prática chega ao pico, os estudantes parecem ter abandonado a órbita da Terra, muitos relatam experienciar êxtase e frenesi. É chegada a hora de descer, da mesma forma que instaura-se o caos, o professor Kapish, com mestria, demonstra-se capaz de poeticamente, através de suas narrativas, conduzir os alunos para a Terra novamente. Instaura-se a quietude e contemplação.

O professor Kapish tem costume de fazer imersões com os alunos do Movimente em meio à natureza. No semestre em que estávamos presentes no curso o professor convidou, tanto os participantes do Movi-mente como os alunos do curso de Corporeidade, para um circuito de imersões que durariam o ano inteiro. Apenas uma aluna do curso de Corporeidade aceitou participar das imersões, aluna que inclusive veremos no Caso Valkyria.

As imersões são formas de intensificar o trabalho do Movi-mente. Os estudantes viajam para cidades no interior do estado do Goiás e acampam durante cerca de três dias em algum local em meio a natureza. Experimentos com o corpo são conduzidos de forma a levar os participantes a conhecerem os limites do próprio corpo, através de práticas de meditação dinâmica, caminhadas longas, silêncio, jejum e contato com a natureza.

As motrivivências do projeto não são fáceis e em determinados momentos trabalham com exaustão física, exigindo bastante dos participantes. Mas o que é colocado como o mais difícil pelos participantes é a dimensão subjetiva da experiência. Em conversas com pessoas que tem alguma prática em meditação, yoga ou já participaram, durante algum tempo, de experiências com psicoterapia corporal é unânime o reconhecimento de que durante essas práticas existe a possibilidade de emergirem em nossas mentes memórias ou conteúdos de difícil integração. Isso ocorre principalmente quando temos a sensação de estarmos contemplando aspectos indesejáveis de nosso ser os quais, até então, não tínhamos consciência. 
Este fator é considerado por nós, também várias vezes explicitado pelo professor Kapish, como um dos motivos responsáveis por afastar as pessoas do projeto. Seria uma espécie de dificuldade para lidar com os indesejáveis aspectos de nós mesmos. Esta dificuldade parece ser transcendida na medida em que se persiste na prática, abrindo a possibilidade de nos tornamos mais tolerantes e acolhedores em relação a nós mesmos.

Há um esvaziamento do curso em dois momentos do semestre. O primeiro é nas primeiras duas semanas de aula, quando o professor apresenta um pouco do que acontecerá durante os semestre. Este esvaziamento acontece porque algumas pessoas não se identificam com o curso e o trancam. Situação que abre espaço para que alunos, numa longa fila de espera, consigam matricular-se. O curso tem muita procura e em todos os semestres está lotado. O outro momento de esvaziamento é quando os estudantes se encontram no período de provas.

Percebemos que apesar do professor manter-se muito aberto para ouvir os estudantes, os mesmos levam algum tempo para que passem a participar ativamente do curso. Foi possível notar que os alunos iniciam o curso com uma postura menos ativa, menos participativa, e conforme avança o semestre os alunos vão se sentindo mais à vontade para contribuir com o desenvolvimento das reflexões propostas pelo professor, tornam-se mais ativos e mais abertos ao diálogo.

De maneira geral o clima das aulas é agradável. É interessante perceber que mesmo os alunos, que por um momento inicial aparentam estar deslocados dentro do curso e do projeto, ao longo do semestre vão se integrando. Durante o semestre a turma parece ganhar um caráter de grupo.

Enquanto participávamos das aulas observávamos os alunos em busca de elementos que indicassem a emergência de processos subjetivos, aos quais pudéssemos associar à constituição de configurações criativas. Apesar de inspirados por recursos subjetivos fortemente associados à criatividade na literatura científica, tais como a reflexividade e abertura à experiência, deixamos em aberto aquilo que buscávamos para que não tentássemos forçar a construção de indicadores.

O objetivo era deixar em aberto a observação do processo de constituição de um novo recurso, que podíamos, inclusive, nem ter nos dado conta previamente. Desta 
forma, ampliando a compreensão sobre a diversidade de recursos que possam emergir favorecendo a criatividade.

\subsection{Construção do cenário social da pesquisa}

Estamos em contato com o projeto de extensão e seu coordenador, há mais de cinco anos e durante o $2^{\circ}$ semestre de 2014 acompanhamos o projeto na condição de pesquisadores. A experiência de um semestre no projeto, como pesquisador, desencadeou um processo de construção dos instrumentos a serem utilizados na pesquisa durante o $1^{\mathrm{o}}$ semestre de 2015 .

Acreditamos que este contato amigável com o professor Kapish facilitou nosso trabalho, pois sempre se colocou em uma postura muito aberta à propostas e está interessado na realização de estudos dentro deste projeto. O projeto Movi-mente foi investigado em seu trabalho de doutorado em Portugal concluído em 2013.

Para a construção do cenário social da pesquisa, no primeiro dia de aula do curso, o professor nos apresentou como o pesquisador que acompanharia a turma naquele semestre. De forma sintética, apresentamos a pesquisa aos alunos do curso, mas entendemos que o mais importante foi a apresentação de nossas motivações pessoais para com o trabalho. Pedimos o auxílio daqueles que sentissem o ímpeto de contribuir.

Como forma de atrair os estudantes para participarem da pesquisa explicitamos que participar da pesquisa poderia ser uma forma se aprofundar no curso. Aprofundar-se neste curso seria para eles uma possibilidade de se conhecerem mais um pouco.

Explicamos um pouco como seria o trabalho e de que forma os sujeitos contribuiriam. Apresentamos o instrumento diário de bordo e explicamos basicamente o que os estudantes deveriam fazer durante sua participação na pesquisa. A ideia foi explicitar que participar da pesquisa não seria algo pesado e não os atrapalharia em sua rotina.

\subsection{Instrumentos}

De maneira geral, através dos instrumentos, buscamos entrar em contato com a história de vida dos sujeitos. Tendo em vista que como buscamos a emergência de novos recursos subjetivos precisávamos ter o passado como referência. Através dos instrumentos nos foi possível descobrir um pouco sobre suas histórias de vida, momento 
presente, formas de perceber o mundo, formas de relacionar-se com o mundo, planos para o futuro e principalmente sua vivência dentro do curso/projeto.

\subsubsection{Observação do curso Corporeidade e Expressão corporal, do Projeto} de Extensão Movi-mente e viagens de imersão.

Como pesquisadores estivemos presentes durante as aulas, no projeto de extensão e também acompanhamos as imersões feitas pelo professor ao longo do ano. $\mathrm{O}$ objetivo é a observação de tal espaço, a interação com o professor, com os alunos e com os monitores. Tal participação fundamentou-se no entendimento de que este momento era essencial para a obtenção de informações, para a composição do tecido informacional e para a seleção definitiva dos sujeitos da pesquisa.

Neste espaço estivemos atentos em como, por exemplo, o professor conduzia a aula, o projeto e como seus alunos respondiam às suas propostas ao longo do semestre. Também foi o espaço em que observamos o processo de entrega dos alunos à prática do Movi-mente e a participação nos diálogos existentes no momento teórico do curso. Analisamos o teor das discussões e como os estudantes reagiam às mesmas. $\mathbf{O}$ roteiro de observação do momentos teóricos, práticos e das imersões se encontra no Apendice I.

Para o relato do curso e práticas usávamos um diário aonde anotávamos tudo aquilo que observávamos e onde já realizávamos construções teóricas a cerca do processo.

\subsubsection{Diário de navegação}

Foram distribuídos aos participantes diários de navegação. O diário consistia em um caderno artesanal colorido pequeno com folhas em branco. A instrução sobre o que deveria constar no caderno foi enviada aos sujeitos via correio eletrônico. Os diários foram entregues apenas aos estudantes que decidiram contribuir com a pesquisa. Pedimos que nele fossem feitas, no mínimo, duas anotações durante a semana.

O objetivo do diário era propiciar ao sujeito um espaço de contínua reflexão sobre o curso e as motrivivências. Buscamos acompanhar a forma como os estudantes vivenciavam este espaço, que tipos de reflexão este espaço provocou neles, como percebiam a si mesmos dentro dos momentos práticos e teóricos. 
Esta é uma forma que encontramos para nos aproximarmos dos sujeitos de pesquisa e de estar em contato com possíveis movimentações que aconteciam ao longo do semestre na subjetividade. As instruções enviadas aos sujeitos de pesquisa sobre o diário se encontram no Apendice II.

As anotações referiam-se aos seguintes pedidos:

- Escrever com detalhes o que foi vivido durante a prática do Movi-mente explicitando suas emoções, pensamentos e principais momentos vividos.

- Caso, durante a semana, lhe ocorresse alguma lembrança da prática do Movimente ou da aula teórica a orientação era para que o sujeito fizesse um relato minucioso de como essa lembrança lhe ocorreu, relatar com detalhes o acontecimento que estava atrelado a esta recordação.

Para além da orientação, citada acima, os estudantes podiam fazer qualquer tipo de anotação neste de diário. A premissa é que suas anotações estivessem atreladas às vivencias dentro do curso de Corporeidade e do projeto Movi-mente.

\subsubsection{Análise documental}

Ao longo do semestre o professor pediu aos alunos que fizessem exercícios reflexivos escritos. As reflexões basicamente eram orientadas com o objetivo de ampliar a consciência corporal dos estudantes e de gerar reflexão sobre aquilo que estava sendo abordado no curso.

O professor pede aos alunos reflexões escritas sobre suas experiências dentro do curso. Também pede para que realizem exercícios de observação e produção de texto sobre determinadas características do corpo, como a investigação de um habito mecânico. Alguns trabalhos, com o aval dos sujeitos de pesquisa e do professor, foram recolhidos para análise.

Os documentos analisados foram:

4. Exercícios escritos pedidos pelo professor.

As tarefas pedidas pelo professor foram recolhidas e utilizadas como fonte de informação sobre o envolvimento dos estudantes com a prática e quais foram seus desdobramentos. Como os exercícios estão sempre destinados a gerar momentos 
reflexivos dos alunos, não são necessariamente uma síntese ou resumo dos textos, nós os utilizamos com o objetivo de investigar as formas de subjetivação do curso por parte dos alunos. Nos privilegiamos de exercícios que dirigem os alunos a uma zona de sentido que está estritamente envolvida com o curso, percebendo em que concentram-se suas reflexões, quais são seus focos e sentimentos em relação ao que estão experienciando. Os pedidos de reflexão, feito pelo professor Kapish, encontram-se no Anexo III.

\section{Análise de Facebook}

O objetivo de investigar o perfil do Facebook dos indivíduos foi a possibilidade de encontrarmos indicadores indiretos de processos subjetivos. O perfil do Facebook, por tratar-se de uma página na internet com informações disponibilizadas pelos sujeitos que datam um período anterior ao do curso, foi uma forma de obtermos informações que nos auxiliaram a hipotetizar transformações na subjetividade.

\subsubsection{Dinâmicas conversacionais}

Como via para obtermos informações relevantes para a pesquisa realizamos dinâmicas conversacionais. O objetivo era criar este espaço dialógico entre pesquisador e pesquisado, buscando conduzir os sujeitos de pesquisa a campos significativos de sua experiência pessoal (GONZÁLEZ, REY, 2005b). Os diálogos facilitam esta possibilidade de juntos, pesquisador e sujeito de pesquisa, criarmos um espaço onde o estudante torne-se capaz de expressar seu mundo, suas crenças, valores, emoções, conflitos e resoluções a respeito de um determinado assunto. Com isso tornando disponível sua trama subjetiva e a maneira como se relaciona com diversos aspectos da vida.

As dinâmicas conversacionais possuiam um caráter aberto e participavamos ativamente da conversa numa busca por dar-lhe novos caminhos. A busca era por contribuir para que o sujeito refletisse e se expressasse com profundidade a cerca daquilo que está sendo investigado por ambos durante o diálogo.

É importante expressarmos, o instrumento de dinâmica conversacional funciona como uma espécie de entrevista, a diferença é que não estamos atrelados e nem buscamos respostas fechadas. Buscávamos conduzir a pessoa a um determinado foco 
onde ela pudesse expressar seus sentimentos sobre um determinado assunto, de modo que pudéssemos acompanhar a forma como ela se expressava.

O roteiro utilizado nas dinâmicas conversacionais se encontram no Apêndice III.

\subsubsection{Completamento de frases}

O objetivo é induzir o sujeito a se expressar sobre um determinado campo de sua experiência através de um processo de completar frases que funcionam como indutores. Os indutores foram articulados de acordo com aquilo que o pesquisador julgou ser importante para o processo de obtenção de informações relevantes para o desenvolvimento da pesquisa.

O instrumento foi adaptado de modo a estabelecer uma relação com o tempo, de forma que algumas frases faziam com que o sujeito se remetesse a momentos como o início do ano, antes de ter passado pelo curso, e também após ter passado por ele. Buscamos induzir a reflexão do sujeito para eventuais mudanças ao longo do ano. Também possuía frases com a intenção de direcioná-los a reflexões sobre temas como o corpo, corporeidade e projeto Movi-mente.

As frases removidas referem-se a maternidade, casamento e filhos. Escolhemos removê-las por não apresentarem-se como essenciais em relação a nossos objetivos e por não terem relações com os sujeitos, tendo em vista que não eram casadas e não possuíam filhos. O completamento de frases se encontra no Apendice IV.

\subsubsection{Composição: Quem sou?}

Este foi o último instrumento aplicado ao término do curso no segundo semestre de 2015. O objetivo era perceber em que medida, no processo de expressão do sujeito acerca daquilo que compreendia ser, surgiam elementos que pudessem estar relacionados com a temática do curso e o projeto de extensão. Utilizamos essa pergunta como indicador de algum tipo de impacto subjetivo que pudesse estar relacionado com este espaço social. O modelo entregue aos alunos se encontra no Apêndice V.

Além dos instrumentos planejados para a obtenção de informações mencionados anteriormente, ressaltamos que também participam do processo de obtenção de informação os momentos informais, não previstos pelo pesquisador. 
Os momentos informais não são considerados um instrumento. São instantes em que o pesquisador, sem que tivesse preparado algo formal, percebesse que o sujeito de pesquisa está expressando algo importante para o desenvolvimento de sua produção teórica.

Os momentos informais podem revelar aquilo que não necessariamente estava intencionalmente sendo buscado. Podem conduzir o sujeito para outros focos, alertando o pesquisador sobre outras possibilidades que ampliam complexidade do estudado (GONZÁLEZ, REY, 2005b).

\subsection{Participantes}

O curso é composto por estudantes de idade que varia dos 17 aos 28 anos de idade. A turma geralmente é mista, havendo equilíbrio entre o número de mulheres e homens. Apesar do curso ser ofertada pela FEF-UnB os alunos que optam por fazê-la são de diversas graduações. Entre eles encontramos estudantes das artes cênicas, pedagogia, serviço social, engenharias, medicina, psicologia entre outros, sendo poucos os alunos que são da Educação Física.

Apesar de transitarmos no projeto Movi-mente, focamos nosso trabalho nos estudantes do curso Corporeidade e Expressão Corporal, esta decisão ocorreu porque a pesquisa dependia de um contínuo acompanhamento dos estudantes ao longo de um semestre. Caso fizéssemos apenas com os alunos do projeto de extensão existia a possibilidade desses indivíduos não aparecerem aos encontros, pois não estão institucionalmente vinculados ao projeto.

Outro motivo que nos levou a escolher os estudantes do curso foi em função deste ser o espaço de reflexão e estudo sobre a dimensão teórica do que acontece durante o projeto de extensão.

\subsection{Procedimentos}

O trabalho de campo foi realizado em duas etapas:

1. Consistiu em nos aproximarmos dos sujeitos de pesquisa e investigarmos sobre: a qualidade das informações nos diários, a assiduidade no curso/projeto, forma de participação no momento prático do curso, nível de implicação do sujeito no curso e 
pesquisa. Com isso foi possível a seleção dos sujeitos para a realização do estudo de caso.

2. Consistiu em concentrar nossa atenção durante as aulas nos sujeitos de pesquisa selecionados para o estudo de caso, aplicação das dinâmicas conversasionais, instrumentos escritos e realização estudo de caso.

A primeira etapa da pesquisa consistiu em encontrarmos formas, nos momentos que tínhamos dentro do curso, de nos aproximarmos dos sujeitos de pesquisa. Também em uma busca por organicidade, de alguma forma perceber se eles também expressavam uma intenção genuína de aproximar-se do pesquisador e implicar-se na pesquisa.

No início havíamos deixado aberta a possibilidade de trabalharmos com até dez sujeitos de pesquisa. Porém não atingimos este número, trabalhamos com oito, três homens e cinco mulheres. A eles foram entregues os diários.

A entrega dos diários aos sujeitos de pesquisa aconteceu no início de março de 2015, na segunda semana de aula. No início do mês de abril de 2015 os diários foram recolhidos pela primeira vez. Ao recolhermos o diário pela primeira vez apenas cinco sujeitos, um homem e quatro mulheres, o apresentaram. Os que não entregaram explicaram que estavam em um momento de muitas atividades e não estavam tendo tempo para escrever nos diários.

Dos oito sujeitos iniciais três não frequentaram o curso com regularidade, estiveram ausentes em boa parte do curso por motivos diferentes. Dos que faltavam, um encontrava-se no período de conclusão de curso e estava ocupado com o trabalho final.

O outro, um aluno da Educação Física, não parecia ter grande afinidade pelos temas discutidos no curso. Aparentemente as discussões também lhe geravam certo desconforto por colocaram em questão suas crenças religiosas. Apesar do aluno não ter dito isto, essa inferência foi feita com base em nós o observamos nas raras vezes em que esteve presente. Várias de suas expressões faciais enquanto assistia à aula, principalmente em momentos quando se discutiam temas considerados tabus, representavam desdenho, como se o professor estivesse dizendo algo sem lógica e sem fundamentação. 
Até tentamos incentivá-lo a participar da pesquisa, pois pensávamos que seria interessante pesquisar um sujeito que não tivesse afinidade com o curso, mas ele se demonstrou cada vez menos interessado em contribuir. Sentimos também um tipo de desconforto por parte dele por ter se disposto a participar e ter desistido.

Outro sujeito ausente, uma garota, não tornou possível estabelecer uma aproximação que nos permitisse descobrir os motivos pelos quais não comparecia ao curso. Sua justificativa por não participar foi que naquele momento tinha outras prioridades.

Dos oito sujeitos iniciais, consideramos ter conseguido nos aproximar de cinco, um homem e quatro garotas. O homem era este que se encontrava realizando seu trabalho de conclusão de curso e de repente desapareceu das aulas.

Ao final do mês de maio de 2015 estávamos trabalhando apenas com quatro garotas, e foram elas os sujeitos dos quais conseguimos ter maior proximidade. Era possível encontrá-las em períodos que antecediam a aula, pois sempre chegavam mais cedo ao Centro Olímpico. E algumas vezes conseguimos pegar carona para casa com duas delas.

Das quatro que chegam até este momento, apenas duas escreveram em seu diário durante todo o percurso. A justificativa por não terem escrito mais em seus diários também estava relacionada ao fato de estarem cursando o último semestre e estarem envolvidas com o trabalho de conclusão de curso (TCC).

Entre as quatro, as duas envolvidas com o TCC também tinham mais faltas. E uma delas, além de ser mãe, frequentemente saía mais cedo da parte prática, pois chegava à aula já cansada do trabalho, o que a restringiu em sua participação do curso/projeto.

Apesar de termos feito a escolha dos sujeitos que participariam do estudo de caso, durante os últimos meses do curso, não excluímos totalmente de nossas vistas os demais sujeitos de pesquisa. Seguimos o curso ainda mantendo um contato com esses sujeitos. Estávamos abertos à possibilidade de observarmos algo que fosse importante para a pesquisa e que inclusive pudesse nos fazer mudar de decisão acerca dos casos. 


\subsection{Formas de análise/construção da informação}

Para a análise das informações utilizamos a Epistemologia Qualitativa de Fernando González Rey. Nesta perspectiva as informações obtidas não se findam, constatando uma verdade última ou um resultado, mas desdobram-se num novo momento de produção teórica, numa nova zona de sentido a partir das hipóteses que surgem durante o processo construtivo-interpretativo.

Elaboramos um modelo teórico sobre o assunto estudado a partir de indicadores, que foram construídos ao longo do desenvolvimento da pesquisa e das hipóteses elaboradas. Os indicadores não foram fornecidos por uma situação ou pelo sujeito, eles surgem de um momento de produção de significado, elaborado pelo pesquisador, rumo a construção de um modelo que permita inteligibilidade ao que é observado (GONZÁLEZ REY, 2005b). 


\section{ANÁLISE E CONSTRUÇÃO DA INFORMAÇÃO}

Conhece-te a ti mesmo.

Oráculo de Delfos

Não há mistério em descobrir o que você gosta, o que você tem e o que você faz.

Chico Science e a Nação Zumbi (1996)

Ao final da primeira e início da segunda etapa, que consideramos ter sido o final do mês de abril de 2015, estávamos trabalhando com três sujeitos de pesquisa. Nosso critério final para seguir a diante na seleção dos dois sujeitos, que participariam do estudo de caso, foram: assiduidade nos momentos teóricos e práticos, participação em imersões, produção contínua no diário e o estabelecimento da comunicação entre pesquisador e pesquisado.

Esses critérios foram estabelecidos porque dependemos de um adequado processo de comunicação entre pesquisador e sujeito pesquisado, como um espaço relevante para a expressão do mesmo. Foi dessa forma que chegamos aos sujeitos de pesquisa Valkyria e Raíza ${ }^{6}$.

Valkyria, a nosso convite, aceitou participar de uma das imersões. Para nossa surpresa, se sentiu envolvida e nos acompanhou nas demais imersões junto ao professor Marcelo durante todo o ano de 2015. Valkyria foi a única aluna do curso corporeidade a aceitar participar das imersões, apesar do convite ter sido feito a todos da turma.

Este contínuo convívio com Valkyria ao longo do ano de 2015 foi essencial para que a escolhêssemos para realizar o estudo de caso. Conseguimos estabelecer o que achamos mais difícil ao longo desta pesquisa, um contínuo espaço dialógico entre pesquisador e pesquisado, e de observação do sujeito de pesquisa.

\footnotetext{
${ }^{6}$ Os nomes dos sujeitos de pesquisa são fictícios. Os nomes fictícios foram utilizados para preservar a identidade das pessoas pesquisadas.
} 
Então para além do curso, estivemos em contato com Valkyria durante todo ano. Acabamos, para além de nos relacionarmos como pesquisador/pesquisado, estabelecendo um forte vínculo fraterno.

Raíza foi escolhida por ter sido dentre os sujeitos uma das pessoas que, durante todo o curso, fez relatos constantes em seu diário. A aluna frequentou as aulas em seus dois momentos. Foi encontrado em seu diário um espaço de expressão de seus conflitos, desde os mais íntimos aos mais corriqueiros de forma muito espontânea. Isso nos permitiu articular uma comunicação fundamental para o desenvolvimento da pesquisa. Por final, um outro fator decisivo na escolha deste sujeito foi a ausência de conhecimento e vivência prévia de contextos semelhantes ao do curso Corporeidade.

Nesta segunda etapa já tínhamos percebido o nível de comprometimento do sujeitos de pesquisa com o curso e se estavam dispostos a concluí-lo. Na segunda etapa, após termos definido quais alunos participariam dos estudos de caso, iniciamos a aplicação dos instrumentos escritos. Aproveitamos para, durante as aulas, nos concentrarmos na observação de um número menor de sujeitos.

Os casos serão apresentados na seguinte estrutura: caracterização geral do sujeito, forma de subjetivação do curso/projeto pelo sujeito e emergência de recurso subjetivos. No caso de Valkyria tivemos elementos para constatar a emergência de recursos subjetivos comumente associados à criatividade. Já em Raíza não foi possível encontrarmos elementos suficientes para hipotetizar tal emergência.

\subsection{CASO VALKYRIA}

Eu sou nada, e tudo, de uma vez só.

Valkyria

\subsubsection{Caracterização geral de Valkyria}

Valkyria é estudante da UnB e aos 24 anos, no primeiro semestre de 2016, está em processo de conclusão de curso. No ano de 2014 Valkyria esteve na Europa através do programa Ciências sem Fronteiras, com o objetivo de aprofundar seus estudos em engenharia. O Programa Ciência sem fronteiras financia bolsas para que estudantes, principalmente para os cursos que estão na área de ciências exatas e desenvolvimento 
tecnológico. Os alunos permanecem durante um ano em outro país, cursando disciplinas relacionadas a seu curso.

$\mathrm{Na}$ Europa V. morava com outros intercambistas. Ela retornou ao Brasil no ano de 2015. No Brasil V. mora com a mãe e com sua irmã mais velha. No primeiro semestre de 2015 participou do curso Corporeidade. Recentemente V. se envolveu com o circo, espaço ao qual tem se dedicado muito quando não está envolvida com as demandas da vida acadêmica.

V. é uma garota muito simpática e reflexiva. Nos momentos em que passamos juntos percebemos nela uma pessoa muito preocupada com sua formação e futuro profissional. Nossa aproximação foi algo muito orgânico, não demorou muito para que estivéssemos à vontade um na presença do outro.

O intercâmbio parece ter sido uma experiência impactante. V. neste primeiro semestre nos expressa várias vezes um delicado momento que enfrenta neste momento de retorno ao Brasil, onde busca integrar o que viveu. Em uma das dinâmicas conversasionais V. refere-se da seguinte forma em relação a ida para a Europa e seu retorno:

é um choque muito grande.. é outra realidade e (...) é uma coisa muito profunda que acontece porque muita gente entra em depressão muitas pessoas tem problemas porque lá é uma outra realidade (...) você volta com a cabeça diferente e os amigos que você tem aqui não estão com essa cabeça diferente que você está.. e os amigos que você fez lá.. você não vai mais conviver com eles todo dia igual você vivia.. era uma família, via todo dia.. comia junto.. e agora você não vê mais essa pessoa.. e as pessoas daqui são pessoas que você não se identifica mais.. então acontece um choque muito grande.. fora o choque de que eu tive que voltar pra cá.. voltar a estudar e trabalhar igual uma louca.. e lá eu não tinha obrigações muito grandes.. tinha faculdade mas eram poucas aulas na semana.. pouquíssimas coisas pra fazer.. e era uma liberdade muito grande... agora (aqui) além de trabalhar tenho a faculdade... então.. enfim.. voltar do intercâmbio são várias questões.. é difícil.. bom eu tava nesse momento.. de não conseguir me identificar com a realidade que eu tava.

A V. que constituiu-se na viagem, busca reintegrar-se a sua "antiga rotina". As aspas são para explicitar que não existe uma antiga rotina, porque a subjetividade de outrora reconfigurou-se. $\mathrm{Na}$ experiência vivida está implicada a subjetividade. A reconfiguração de sua subjetividade individual, que ocorre na viagem, não permite que o cotidiano de V. seja percebido por ela da mesma forma. 
Para além das questões de inserção na rotina, V. também explicita o quanto também é difícil relacionar-se com as antigas amizades, pois sente que sua percepção de mundo e das coisas, transformou-se de forma significativa. Segundo V. sua busca por espaços como o Movi-mente constituem sua busca pelo autoconhecimento, fator que ela sente ser essencial para realizar este processo de reintegração com seu cotidiano.

Em nossos diálogos com V. percebemos este momento em que suas reflexões e ações centram-se numa busca por compreensão de si mesma e uma tentativa de ampliar sua visão sobre a existência. Também é permeada pela anseio de encontrar compreensões que lhe permitam interpretar e viver a vida de forma satisfatória. A essa busca V. da o nome de autoconhecimento.

\subsubsection{Forma de Subjetivação do curso Corporeidade e do Projeto Movi- mente}

Valkyria foi uma pessoa que esteve presente em quase todas as aulas. Somente esteve ausente nos momentos em que em outras disciplinas encontrava-se no período de provas, no meio e no final do semestre. Havia nesta estudante um interesse muito grande pelo curso. Podemos dizer que sua motivação mantinha significativa ligação com a proposta do curso, conhecer-se. A jovem, tanto nos instrumentos como momentos informais, constantemente declarava que vivia um momento conflituoso e que acreditava que poderia ser superado através do autoconhecimento.

Isso expressava-se tanto nos livros que garota estava lendo sobre interpretações da física quântica por Stephen Hawking. Também, no início do ano, estava frequentando aulas de Kundalini Yoga.

Quando perguntei a ela, logo na segunda aula, sobre sua percepção sobre questões religiosas, investigando se a aluna tinha alguma crença e se era adepta de alguma religião, ela nos disse que não. Porém que naquele momento, mais do que outros em sua vida, estava abrindo-se para investigar aspectos relacionados a sua espiritualidade.

Por vários momentos V. se referiu ao Movi-mente como um espaço que conduzia ela ao autoconhecimento. Vejamos alguns trechos que surgem nos instrumentos que nos levam a tecer considerações sobre o processo de subjetivação do curso por Valkyria. Perguntamos a ela o que seria este autoconhecimento dentro deste projeto/disciplina: 
eu acho que é uma coisa sobre mim.. sobre os meus gostos.. sobre o que eu quero fazer... sobre o que eu gosto de fazer o que eu não gosto.. o que eu quero pra minha vida.. sabe? o que eu quero pra minha vida e tipo assim.. entender isso.. porque assim, se a gente não entender e buscar nossas vontades a gente vai estar a mercê das coisas e não vai chegar a lugar nenhum... (Dinâmica Conversasional)

Perguntamos a V. se ela recomendaria o projeto a alguém, ela nos afirma que sim. Explica que naquele semestre em vários momentos se percebeu tentando explicar o projeto enquanto fala do mesmo para as pessoas que lhe eram queridas. Perguntamos a V. o que ela fala para as pessoas sobre o curso/projeto e V. responde:

eu falo que é meio que uma busca pela espiritualidade através do corpo.. através do contato com as pessoas.. falo que tem uma coisa meio teatral e uns exercícios.. falo isso.. sair da sua área de conforto e que é muito interessante.. é mais nesse sentido mesmo e que é a forma que eu consegui explicar... (Dinâmica Conversasional)

V. tanto em momentos informais, como nas dinâmicas conversasionais nos disse que vivia uma espécie de conflito com base naquilo que percebia emergindo em função de sua participação no curso.

Em uma das dinâmicas conversasionais $\mathrm{V}$. chorou ao expressar desconforto por sentir que havia uma divergência entre aquilo que havia escolhido para si e as coisas que ela entendia gostar. V. declarava-se uma amante da natureza e por isso optou pela área da engenharia florestal. Porém a dimensão profissional que abria-se em relação a seu curso, naquele momento, era difícil de ser vista por ela como algo que contemplasse seus anseios mais profundos.

O conflito surgia pois V. sentia que foram poucos os momentos em sua vida em que se dedicou àquilo que gostava. Sentia que sua prioridade não estava em dedicar-se àquilo que gostava, mas dedicar-se a escola. Vejamos o trecho em que V. se expressa em relação a sua vida escolar:

eu sempre fui de estudar muito.. nerd de tirar nota alta.. então o foco da minha vida sempre foi estudar.. ensino médio.. eu sempre estudei.. tudo o que eu sabia fazer era estudar e tirar nota boa.. e aí eu não tava preocupada com outras coisas.. fazer coisas que eu gosto.. e aí eu acho que eu deixei.. então.. a minha prioridade sempre foi a faculdade.. sempre foi ensino médio.. sempre foi aula.. sempre foi estudar.. tipo assim.. eu deixava de fazer tudo na minha vida tipo eu deixei de fazer coisas que eu gosto porque meu objetivo é estudar... (Dinâmica Conversasional) 
Percebemos que os sentidos subjetivos que permeiam sua vida escolar são paralelos àquilo que lhe dá prazer, aos seus anseios mais profundos. A escola era uma espécie de demanda externa a ser comprida de forma obrigatória, para conseguir uma vaga no vestibular e consequentemente ingressar no mercado de trabalho.

Ela nos relatou uma série de atividades que apesar de gostar, não conseguiu dar continuidade, pois expressou que sua dedicação estava na maior parte do tempo, centrada em atender da melhor forma possível as demandas escolares. Tal foco nas demandas escolares fora expressado com um ar de preocupação, em determinado momento, antes de nossa última dinâmica conversasional, como se tivesse feito algo de errado.

V. durante as dinâmicas conversasionais e demais instrumentos escritos não fala sobre sua família, exceto em uma imersão no mês de julho e no instrumento completamento de frases. Vemos a jovem expressar uma preocupação em relação a mãe. Os pais de V. haviam separado-se pouco antes dela viajar para fora do país. O que para nós é um indicador da presença de um espaço de conflito que também busca ser superado através das relações de V. com espaços como o curso/projeto.

Durante alguns momentos, após o mês de julho $\mathrm{V}$. conversava muito conosco e com os outros colegas das imersões sobre relacionamentos, sobre um temor acerca de sua capacidade de relacionar-se.

Em agosto nos encontramos para uma última dinâmica conversacional, V. estava leve. Quando perguntamos a ela como ela se sentia, ela nos respondeu: "agora, esta tudo bem", expressando que havia passado seu momento difícil. Ela nos relatou sentir que havia encontrado uma forma de integrar aquilo que gosta com aquilo que era sua vida acadêmica e seu trabalho. Se tratava de dedicar-se a uma coisa, mas sem com isso perder ou deixar de lado os momentos que representavam para ela aquilo que gostava. Ela expressava ter encontrado um ponto de equilíbrio, principalmente por sentir que finalmente persistia em algo que gostava.

Para V. este local foi encontrado no circo, na prática de tecido acrobático. No mês de novembro encontramos em seu perfil de facebook dois convites para aulas de tecido acrobático, que agora eram ministradas por ela junto a uma amiga. A jovem parecia ter 
alcançado uma de suas metas: encontrar algo que se sentisse bem e pudesse servir o mundo.

Perguntamos a ela quais eram suas preocupações com sua mãe. V. nos relatou que acreditava que sua mãe estava muito distante de espaços que fossem conducentes a este autoconhecimento. Expressava alívio e gratidão por sua participação nesses espaços e desejava também que a mãe tivesse a oportunidade de desfrutar do que ela havia encontrado ali.

V. entendia ter encontrado bem-estar e plenitude. Quando perguntamos o que a preocupava em sua mãe ela nos respondeu que era sua excessiva e estressante preocupação com o cotidiano e suas obrigações. Seu rosto assumiu uma postura reflexiva quando perguntamos se ela não percebia-se tão preocupada quanto a mãe em relação a sua vida acadêmica e profissional. Ela nos confirmou com um certo espanto e depois um sorriso.

No diário, pedimos aos sujeitos de pesquisa que fizessem anotações, não apenas sobre as aulas e sobre as motrivivências, mas que também fizessem anotações durante a semana, sempre que algo que acontecesse os levasse a lembrar do curso. No mês de junho encontramos a seguinte anotação na primeira semana:

Ontem fui andar de bicicleta e senti um bem estar tão grande, depois de passar dias fazendo um trabalho que me deixou bem tensa, o prazer e a liberdade de poder fazer algo que eu gosto por simples lazer. Essa sensação de paz e liberdade me lembraram o movimente, sensações e sentimentos que tenho nas práticas. (Diário)

E na semana seguinte, após uma aula que falava a busca por investigar hábitos automáticos e romper com eles:

Essa semana me libertei das amarras do cotidiano. Me despreocupei com os compromissos acadêmicos e fiz uma cosa diferente. Dei uma pedalada com uns amigos da UnB até a casa de um deles no córrego do urubu, aconchegante a casa, deu pra me sentir no meio do mato. Voltamos hoje para pegar a aula das $08 \mathrm{~h}$. Sei que esse desapego, relaxamento, paz, tranquilidade, fugir do hábito devo muito às reflexões do movimente tem inspirado em mim. Sobre priorizar minhas vontades, meu bem estar, minha qualidade de vida e paz interior! (Diário)

Vejamos também elementos que surgem no completamento de frases que usamos como indicadores de seu processo de subjetivação do curso: 
12. No Movi-mente... Aprendi

18. Corporeidade... é Sentir

21.Meu maior problema... me entender

33. Sinto dificuldade... de me conhecer

34. Meu maior desejo... é encontrar a felicidade plena

Certa vez encontramos V. na UnB e lembramos a ela sobre a imersão que haveria naquele final de semana. Ela havia esquecido e com um ar de alívio nos disse: "Ai que bom, estou precisando mesmo, minha energia está baixa". A jovem referia-se a seu sentimento de vitalidade.

A partir dos trechos exibidos por nós, concluímos parcialmente, que os sentidos subjetivos gerados por $\mathrm{V}$. em relação ao Movi-mente estão relacionados ao ato de conhecer, experimentar e refletir sobre si mesma. Inquirir a si mesma acerca daquilo que realmente gosta, o que V. denomina como estabelecer contato com sua essência, com sua espiritualidade através do corpo propiciando autoconhecimento.

Encontramos uma produção subjetiva relacionada ao bem-estar. Em relação ao espaço do Movi-mente V. expressa seus sentimentos de relaxamento, tranquilidade, paz e qualidade de vida. É para ela um espaço que, apesar de acadêmico, rompe com a lógica dos demais espaços que encontrou tanto na Universidade como em seu tempo de escola. É um espaço para cuidar de si mesmo, entrar em contato com o outro, é concebido para V. como um espaço terapêutico.

V. expressa gratidão como se as vivências tivessem oportunizado a ela a possibilidade de produzir novos sentidos subjetivos que são capazes de alterar seu referencial acerca do que é a qualidade de vida. Auxiliado a direcionar mais cuidado com seu corpo e estar mais próxima daquilo que lhe é aprazível.

\subsubsection{Emergência de Recursos Subjetivos associados à Criatividade}

\section{Desinibição, aceitação de si e autoconfiança}

Dentre os movimentos na subjetividade de V., o que nos chama mais a atenção é sua produção subjetiva relacionada a aspectos constituintes de pessoas consideradas criatvas: a desinibição, aceitação de si e autoconfiança (MASLOW, 1968; ROGERS,1984; MITJÁNS MATÍNEZ, 1997). 
É importante lembrar que entre as motrivivências do Movi-mente um dos temas frequentemente trabalhados é o ridículo. Existe a máxima dita pelo professor Kapish: “Ame e dê vexame!”. Como expressado pelo professor, algumas experiências são desencadeadas com a finalidade de romper com estruturas constituídas na pessoa que lhe impedem de se expressar com autenticidade. O receio de ser ridículo e julgado são partes dessas estruturas que impedem a expressão autêntica e criativa.

Este receio de ser ridículo mantém, em certos casos, uma relação com os sentidos subjetivos que a pessoa produziu em relação ao outro, do que é que pode ser expresso diante desse outro. São sentidos subjetivos relacionados às convenções sociais e como relacionar-se com elas. No diário de bordo, ao longo do semestre, V. vai explicando como se sente em relação as práticas e aos outros que estão próximos a ela.

Logo no início do semestre V. explicita em seu diário de bordo um pouco de vergonha que sentia durante as práticas. Justificava principalmente por não conhecer as pessoas e envolver-se em uma prática que envolvia elementos que, para ela, eram de cunho íntimo. Por exemplo, uma prática que aconteceu logo nas primeiras semanas, receber e fazer massagens em pessoas desconhecidas durante a temática que discorria sobre o sentido do tato. ${ }^{7}$ No início de março V. escreve em seu diário:

No início sempre fico inibida pensando o que os outros vão pensar se eu fizer tal coisa, mas penso que ninguém ali tá preocupado em julgar as atividades de ninguém e que todo mundo está na mesma situação, e isso é lindo, no mundo lá fora, parece que estamos sendo julgados e analisados o tempo inteiro."

A jovem expressa sobre a liberdade que sente em relação a um espaço onde não sente que está sendo julgada, em contraposição a outros espaços onde frequentemente sente-se julgada. Isso sinaliza uma produção de sentidos subjetivos de acolhimento de si na condição de expressão de sua autenticidade.

Entendemos que este momento no início do semestre constitui o início de indicadores sobre a produção de sentidos subjetivos relacionado ao outro e a si mesma. Gradativamente, ao longo do semestre, essas produções intensificam-se e passam

\footnotetext{
${ }^{7}$ Durante o semestre o professor guia os alunos numa jornada pelos 5 sentidos e incluí entre eles um sexto sentido, que é entendido como o sentido da mente. Em tradições como o hinduísmo e o budismo a mente é entendida como um sentido. Durante as aulas o professor diz que segundo essas tradições, a mente é único sentido que é capaz de criar aquilo que sente, o pensamento é o objeto sentido pela mente e simultaneamente uma produção dela mesma.
} 
constituir elementos subjetivos constitutivos de configurações criativas expressas, neste caso expresso na desinibição, aceitação de si e autoconfiança.

Ao final do mês de março V. exprime em seu diário como acredita que o Movimente está alterando sua forma de se relacionar com outros espaços:

Outra coisa que pude perceber durante essas oficinas (de circo) é como eu me sinto mais à vontade na presença de grupos de pessoas desconhecidas." $E$ eu acho que devo isso ao movi-ment pois já tinha feito coisas "muito piores" nos encontros (do movimente). Haha!

As coisas "muito piores" a que V. refere-se são as motrivivências em que existe a necessidade lidar com o ridículo ou com situações de intimidade dentro de um espaço onde não conhece as pessoas de forma íntima. Sua própria corporeidade ainda é um espaço restrito a ela mesma, até mesmo estranho e novo como veremos mais adiante.

Há momentos em que a produção subjetiva de V. dentro deste espaço aponta para uma vivência positiva onde sente-se à vontade e acolhendo a si mesma. Tal contexto se expressa no mês de maio durante uma motrivivência onde os alunos juntavam-se em grupos com o objetivo de gerar estímulos nos corpos uns dos outros. A finalidade é de sentirem na pele as polaridades entre sensações agradáveis e sensações desagradáveis. Esta motrivivência estava dentro da temática de conhecimento sobre o órgão da pele e do sentido do tato. Vejamos:

Várias coisas vão passando pela cabeça, primeiro, a preocupação: Que droga, coitados, minha perna não está depilada”, e coisas do gênero supérfluas. Mas é claro que no final ninguém está se importando com isso, afinal, estamos trabalhando com algo muito maior. (Diário - maio)

E mais uma vez sobre a imersão em junho na Chapada dos Veadeiros V. expressa:

Me senti muito a vontade com o grupo, senti uma energia muito forte entre as pessoas, de cuidado, carinho, preocupação, muito amor. Com certeza as práticas no movimente me ajudaram com relação disso, me soltar, perder timidez, nesse sentido. (Diário - julho)

Vemos no trecho do diário de V. o que para nós é indicador também de um processo de intensificação ou constituição do elemento reflexão sobre si, que leva os 
estudantes a fazerem tais constatações sobre suas mudanças. Falaremos sobre a reflexão sobre si em separado mais a adiante.

Sobre o dia de avaliação do curso V. expressa em seu diário:

Foi muito interessante ouvir o relato tão profundo de pessoas que eu nunca tinha conhecido e conversado. Pessoas que eu tinha um préjulgamento mas que não fazia a menor ideia do tanto de pensamentos e emoções que passava na cabeça da pessoa e carinho pelas pessoas. uma espécie de identificação e compartilhamento de sentirmos respeito. Incrível como uma turma inteira consegue se desvencilhar de amarras e padrões, e abre mão de vaidades para expor seus sentimentos de forma tão sincera.

Percebemos que as produções subjetivas dentro deste espaço conferem-lhe um sentimento de ser respeitada como ela é. Esse contexto abre espaço para a emergência de uma produção de sentidos subjetivos relacionados ao acolhimento de si mesmo, de confiança e aceitação diante que se está sendo.

As expressões de $\mathrm{V}$. que nos levam a parcialmente concluir que durante o trajeto do curso ocorre o desenvolvimento de recursos subjetivos como a desinibição, aceitação de si e autoconfiança também expressam-se no instrumento das Dinâmicas Conversasionais.

Houve um dia, cerca de um mês após o término do curso, que realizamos uma Dinâmica Conversasional e foi interessante perceber que $V$. vestia roupas muito curtas e rasgadas. Era nítido que a garota havia mudado completamente de estilo de um formato bem conservador de se vestir, para uma espécie de estilo neo-punk. Em sua cabeça estava um novo e inusitado corte de cabelo, comum entre os artistas de circo, com a lateral da cabeça raspada enquanto o restante do cabelo continuava grande.

Ficamos contentes com a mudança radical que se apresentava com a forma autentica de $\mathrm{V}$. se expressar. O que para nós em alguma medida reafirma este movimento subjetivo de aceitação de si, autenticidade e desinibição.

Vejamos um trecho da dinâmica conversasional que foi realizada ao final do semestre. $\mathrm{O}$ dialogo relata momento em que $\mathrm{V}$. começa a falar sobre possíveis alterações em seu comportamento em contextos cotidianos:

...hoje em dia (eu frequento o centro acadêmico do meu curso) porque eu sei que eu não tenho que provar nada pra ninguém, provar que eu sou nada.. porque eu, sou o que eu sou. Eu to muito satisfeita com isso, muito feliz com isso.. entendeu? por exemplo.. essa aula de circo que eu fui fazer com as minhas amigas.. tem muita gente diferente e uma pessoa quer mostra também que é melhor do 
que a outra.. e é uma coisa que eu não estou também preocupada.. porque você está ali pra fazer a aula sabe.. e eu não estou preocupada com o julgamento das pessoas e eu me senti a vontade mesmo estando com pessoas desconhecidas e tendo que fazer coisas que eram completamente diferentes para mim.. uma dança de pole dance, uma coisa sensual. A sensualidade por exemplo, é uma coisa que eu nunca trabalhei... não flui muito enfim... e é uma coisa que foi completamente diferente mas eu me senti super à vontade... tava nenhum pouco preocupada com as pessoas sabe... E aula de dança também... eu tive dança do ventre aí tinha gente ficava muito fechado, você via que as pessoas estavam com vergonha... não conseguiam se soltar... e é uma coisa que eu comecei a ficar muito mais tranquila depois do Movi-mente.

Já ao final do processo V. expressa que não há mais a necessidade de aprovação de um outro. Atitude que nos indica uma produção subjetiva sobre si em relação ao outro que a leva sentir-se mais confiante sobre sua existência.

Já que V. fez a associação de suas mudanças com o Movi-mente, perguntamos a ela: ausência de vergonha nela tinha haver com o nível em que as coisas aconteciam no Movi-mente? Não explicitamos o nível de quê, para que ver o quê a garota responderia. A jovem, de forma muito empolgada, expressou satisfação por nós termos lhe auxiliado a compreender o motivo de estar sentindo-se mais aberta em ambientes onde outrora sentia-se envergonhada e nos respondeu:

Exatamente! Porque o Movi-mente é uma coisa de tanta intimidade que você faz ali também com pessoas desconhecidas que você.. enfim, acho que em nenhum lugar você vai passar algo daquilo.. não existe limite no Movi-mente.. né? E os outros lugares tem limite.. então eu me sinto completamente à vontade em fazer outras coisas em outros lugares.

E complementa dizendo o que aprendeu:

Então eu aprendi a aceitar muita coisas sabe, e a respeitar mais meu corpo do jeito que ele é então... nessas práticas do Movi-mente eu nunca.. eu não me sinto desconfortável com isso.. eu nunca tive isso porque eu acredito que as pessoas que estão ali não estão pra te julgar sabe.. é uma liberdade muito grande.. é uma liberdade que você tem de Ser você mesmo.. ter os seus defeitos e sinceramente eu acho que ninguém ali ta nem um pouco preocupado porque está todo mundo ali se expondo também.. e isso que é muito fantástico!

Mais uma vez, agora nas dinâmicas conversacionais, V. apresenta sua produção subjetiva nos momentos experienciados por ela ao longo do curso. É observado a presença de sentidos subjetivos relacionados a uma satisfação que vem da liberdade de ser ela mesma. Inclusive de reconhecer próprios defeitos e aceita-los, o que também é 
explicitado por Maslow (1968) como algo por ele percebido em pessoas criativas, uma aceitação de sua discrepâncias.

Vejamos como a produção subjetiva de V., dentro deste espaço, acerca do curso e prática está sempre associada a liberdade de expressar-se autenticamente:

Tipo.. sei lá.. você vê que tem pessoas no início.. na primeira da vez da pessoa.. que ela fica preocupada com certas coisas que... velho.. eu não to preocupada e ninguém ta preocupado.. por exemplo... teve um menino que.. numa aula.. que a gente tinha que fazer acho que fazer um alongamento na pessoa.. e era eu e mais duas meninas mexendo em um menino e aí tinha que fazer uma massagem alongar e ele tava todo preocupado.. ele falava: gente é porque eu suo muito.. na minha mão e no meu pé. Eu falei: "gente.. que que tem?" Tipo assim.. eu pensei.. pô to aqui e nem depilei minha perna tipo várias coisas que ninguém tem que se preocupar.. e acho que quando você se entrega mesmo às práticas do movi-mente você não vai estar preocupado com isso.. porque cara isso não é nada.. sabe? Se a pessoa ta com cecê ou tá com qualquer coisa que sinceramente EU NÃO ESTOU PREOCUPADA... Eu não to preocupada se eu depilei a perna.. tipo assim é uma coisa que eu deixei de me preocupar em questão disso.. você desapega total dessas coisas porque o objetivo ali é uma coisa muito maior.. a interação é uma coisa muito maior.. o que você sente é uma coisa muito maior que isso que num vai fazer diferença se sua mão ta suada.. é isso que eu acho fantástico.

V. também produz sentidos subjetivos relacionados a interação entre as pessoas no espaço em questão. Ela nos parece viver um momento único onde o essencial não está nas aparências ou na "superfície" das pessoas, mas sim na interação e na possibilidade de sentir algo maior. A este algo maior expressado por V. entendemos que esteja relacionado a uma produção de sentidos subjetivos que atribuem ao outro uma dimensão muito mais profunda, para além do que é sentido através dos olhos e de nossas interpretações analíticas do outro. Esta interação não verbal e não visual ${ }^{8}$, mas que ocorre através da sensibilidade táctil entre os corpos, constituí-se como possibilidade produção de sentidos subjetivos sobre o outro profundo. Simultaneamente acontece a produção de sentidos subjetivos que atribuem profundidade e singularidade à sua própria existência.

Finalizando com as informações do diário de V. trazemos o último trecho escrito. Esse foi expresso por ela quando pedimos que explicasse o que é que ela queria dizer

\footnotetext{
${ }^{8} \mathrm{Na}$ maioria das motrivivências, exceto as que se relacionam com o tema da visão, as luzes mantém-se apagadas. Pois um dos objetivos seria sentir corporalmente aquilo que os olhos não conseguem ver.
} 
quando utilizava a palavra autoconhecimento. Então nos contou sobre o que consiste para ela o desdobramento de se trabalhar com foco no autoconhecimento:

... e cara é muito diferente quando você começa a trabalhar isso que eu falei... você fica menos preocupado com o julgamento das pessoas, você deixa de querer ser uma pessoa que você não é.. quando você começa a buscar o autoconhecimento.. porque eu sempre tive esse problema... sempre tive a autoestima muito baixa... muito mesmo... então.. acaba que você tenta sempre ser uma pessoa que você não é porque você sempre acha que o que você é não é o suficiente não é tão bom quanto uma outra pessoa... mas quando você busca o autoconhecimento você vê que é uma coisa que você não vai mudar... você aprender a gostar de você assim... dos seus gostos e cara você vai criando uma paz interior... a sua mente... o ego... se aquieta um pouco de querer a ser aquilo que você não é e querer estar em destaque alguma coisa em que você não precisa estar...

Percebemos que dentro deste contexto a jovem produz sentidos subjetivos que lhe conduzem a um processo de aceitação de si mesma, na medida em reconhece que conhecer-se não é necessariamente mudar, mas inclusive aceitar o que está lá. Veremos um pouco adiante como esse processo de aceitação de si a leva a compreender que existem prazeres que ela se negou para construir uma carreira profissional. A forma como se percebeu negar envolver-se com as coisas que lhe davam prazer e que aparentemente não mantinham um elo com o que ela acredita ser sua carreira profissional.

Observemos expressões que corroboram com nossa hipótese sobre a constituição de elementos relacionados a configurações criativas no instrumento Completamento de Frases:

27.Quero ser... eu mesma

50. As contradições... existem dentro de mim.

Estas duas frases nos chamaram atenção por expressarem congruência com indicadores anteriores. Ambas relacionadas ao reconhecimento de suas próprias contradições e o desejo de ser ela mesma.

Então quando V. diz desejar ser ela mesma, intuímos que tal afirmação mantenha uma conexão com essa concepção de Ser apresentada dentro do Movi-mente e do curso de Corporeidade. Neste espaço, Ser você mesmo significa estar livre de padrões psicológicos que lhe oprimem e causam sofrimento. É estar em contato com o que Rogers (2009) chamou de tendência para caminhar rumo à maturidade. A 
nomenclatura que estamos utilizando neste texto ao explicarmos a concepção de Ser usada pelo Movi-mente é a mesma que é utilizada dentro deste contexto.

Enfim apresentamos um momento expressivo do último instrumento a Composição:

Porém, venho percebendo e aceitando, que sou um movimento só, que sou a própria mudança do ser, inconstante por si. Existem ainda infinitas descobertas a serem feitas, assentadas em milhões de possibilidades. A cada nova descoberta me vejo em um processo diferente, que envolvem e acarretam em mudanças. Sei que estou em uma fase de transição, entre o ser que era antes o que virei a ser, mas isso não implica em minha não existência atual.

Os sentidos subjetivos expressados versam sobre uma existência processual, impermanente e inacabada. Ela expressa estar percebendo e aceitando, ou seja, aceitando a si mesma em sua existência complexa e mutável.

Outro fator que utilizamos como indicador para a construção teórica acerca da constituição subjetiva de V. foram nossas observações dentro de sala de aula, práticas e durante as imersões. Notamos uma mudança em sua participação nas aulas e nas práticas ao longo do semestre. No início das práticas, como expressa nos instrumentos escritos, V. estava mais recolhida, expressando introversão, sentimento que ao longo das práticas foi mudando.

Existem dois tipos de prática basicamente, as vezes os estudantes recebem uma tarefa objetiva a ser feita, como uma massagem em algum colega. Ou pode ocorrer um outro tipo de prática que é muito típica do Movi-mente onde, ao som de músicas, o professor constrói uma espécie de história por onde vai guiando os estudantes em vários atos. Nessas vivências os participantes que desconhecem o trabalho do Movi-mente, principalmente os do curso Corporeidade, por vezes demoram algum tempo para integrar-se à prática.

Percebemos que V. vai se sentindo cada vez entregue, seus olhos já estão fechados nas práticas onde a proposta é manter os olhos fechados. E nas práticas mais aleatórias, o segundo tipo que citamos no parágrafo acima, sua participação torna-se mais fluída. Chega a um momento do semestre em que V. aparenta ser uma veterana do projeto, pois está realmente entregue.

Se torna inclusive memorável uma aula onde, além de trabalharmos o paladar, as pessoas deveriam montar um personagem fazendo uma relação com os sabores que 
haviam sentido. Várias fantasias estavam dispostas na mesa. Após isso os estudantes deveriam fazer uma dança para a turma toda e de frente para o espelho, ao mesmo tempo. V. nos surpreendeu, junto a uma garota que simplesmente tomaram a frente do grupo e fazendo uma dança sensual, cômica e ridícula ao mesmo tempo. V. estava muito a vontade, alegre e havia trazido a tona seu ser brincante.

Sua participação ao longo das aulas também aumenta. Faz mais perguntas, vai a frente junto ao professor para servir de modelo para a turma, auxiliando algo que o professor deseja explicar.

\section{Reflexão sobre si}

Outro elemento que percebemos com muita intensidade durante o processo foi a Reflexão sobre si. Esse parece ter sido elemento fundamental para que Valkyria encontrasse vias de avaliação dos próprios conflitos e qualidades. Também lhe auxiliou num processo de construção da via de superação de seus conflitos. Vejamos alguns trechos utilizados para a construção de indicadores acerca da reflexão sobre si:

Confesso que nunca tinha parado para pensar na importância da pele, não só como órgão físico, mas também como intermediador do contato entre eu e o mundo, os outros seres, os bichos, as plantas o clima, as texturas.. (Diário - março)

Vejamos o trecho em que ela se reporta à primeira imersão do Movi-mente Ser no mês de maio:

A primeira vez que a gente foi lá na imersão na Ilumina.. em momento nenhum eu pensei no meu curso cara.. eu fiquei muito chocada quando eu parei pra pensar.. que em momento nenhum eu me vi fazendo o que eu estudo sabe... e cara isso é única certeza que eu tive na vida e porque que em um momento tão profundo em nenhum momento eu pensei no meu curso? nenhum momento! e isso foi uma coisa que me intrigou muito.. e daí eu fico pensando.. como que eu vou relacionar essas coisas sabe (Dinâmica conversasional - junho)

E o trecho do diário, semana após a aula em que se falava da necessidade de se romper com padrões autômatos inconscientes:

Hoje no início da aula conversei com algumas pessoas e todos estavam relatando o quanto o movimente está sendo importante para elas, como estão reparando mais em algumas coisas e se sentindo mais leves... Parei para pensar sobre a minha realidade e estou muito bem também, não sei se atribuo essa mudança apenas ao movimente, mas com certeza ele é o principal motivo (Diário - junho) 
No instrumento completamento de frases a garota também expressa reflexão sobre o vivido:

24. Estou melhor... agora
29. Nesse ano,,, eu mudei

48. No início do ano... eu era uma pessoa diferente.

38. Nos últimos meses tenho me sentido... mais plena

50. Percebo mudanças... em mim mesma, no meu dia-a-dia

E no instrumento Composição a jovem apresenta até mesmo um desfecho para um conflito que lhe acompanhou durante o ano:

Me sinto dividida entre duas paixões, uma delas, nem coloco mais como a engenharia florestal em si e suas múltiplas atividades possíveis entre seguimentos produtivos ou conservacionistas, mas coloco a natureza como minha paixão. Faço assim, uma escolha, a conservação, o estudo da natureza viva.

Voltando a história da arte, a que venho me entregando é a arte do corpo, a consciência do corpo, as infinitas possibilidades de exploração desse templo, o respeito e a união entre o corpo e a mente. Neste sentido, venho passando por mudanças profundas, desde a alimentação, ao estudo do corpo espiritual. A partir disso surgem tantas descobertas espirituais que, acredito eu, tem influenciado e adubado as infinitas descobertas de mim.

Durante todo o processo percebemos o quanto havia por parte de V. um constante exercício da reflexão sobre si. Ela atinge o objetivo do curso, que muitas vezes é afirmado pelo professor como se conhecer. Desta forma é completamente compreensível e desejável, por parte do curso, que seja um processo onde percebamos a intensificação da Reflexão sobre si.

Para nós indicadores que confirmam a emergência deste recurso subjetivo se expressa em todo o percurso e em todos os instrumentos como podemos perceber nos trechos apresentados acima. V. está constantemente refletindo sobre seu trânsito dentro desses espaços, está refletindo sobre suas experiências, sobre situações do passado, sobre seus equívocos e seus acertos. Todo o processo é permeado por um constante exercício de reflexão sobre si, o que entendemos que fora intensificado pelos instrumentos escritos e principalmente pelas dinâmicas conversasionais.

Durante o ano, V. tornou-se muito próxima de nós. Nestes processo de envolvimento com grupos que trabalham com vivências com o objetivo de autoconhecimento é comum encontrarmos alguém com quem nos identifiquemos e 
partilhemos aquilo que está acontecendo conosco. Acreditamos que nos tornamos esse ponto de apoio para $\mathrm{V}$.

Em vários momentos a jovem partilhava suas reflexões conosco, partilhava suas experiências que basicamente se tratavam de um processo de reflexão sobre si mesma em relação a própria existência cotidiana, ao mundo e aos diversos outros. O processo de reflexão certamente é algo que permeia a vida humana, diferenciando-se em seus graus de indivíduo para indivíduo. Mas torna-se claro que a jovem tem intensificado um processo de reflexão, não apenas sobre o mundo e sobre as coisas do mundo, mas principalmente sobre si, sobre suas relações consigo mesmo, com os outros e com as situações de seu cotidiano.

\subsubsection{Outras movimentações na subjetividade}

\section{Corporeidade e novas crenças}

Hipotetizamos a existência de um processo de produção subjetiva a cerca da corporeidade e a assimilação de novas crenças. A corporeidade como apresentada no Movi-mente movimenta uma série de sentidos subjetivos relacionados a existência e seu sentido e ao corpo-mente. Também percebemos a emergência de uma espécie de zona de sentido que integra-se ao processo de reflexão sobre si.

Ao longo do semestre começa a surgir no vocabulário de Valkyria uma série de palavras, como energia, mente, consciência, consciência universal, mundo espiritual/material, chakras, dharma, iluminação e ego. Esses são termos que transitam com frequência dentro do curso e que possivelmente integram núcleos constituintes de configurações subjetivas que participam do processo de reflexão sobre si.

Esses termos, na assunção deles na perspectiva do curso Corporeidade, mantém relação não com as bases da ciência moderna, mas essencialmente com a sabedoria antiga. Assimilá-los implica a emergência de uma nova concepção de ser e de existência que desdobram em numa nova forma de percepção e relação consigo e com os outros.

O conceito ego, por exemplo, é muito usado pelo professor durante as aulas. Esse surge em vários momentos de diálogos e diários de V. como que um ponto de referência desindentificada em relação a si mesmo. Funciona como uma possibilidade 
de falar de si mesma e refletir sobre si mesma, sem sentir agredida ou desconfortável. Torna-se um ponto de referência para que V. desenvolva franqueza ao olhar para si.

Vejamos alguns trechos considerados indicadores de uma nova produção de sentidos subjetivos relacionados ao corpo e existência. Trechos em que V. expressa novas percepções sobre o próprio corpo. Onde também surge este processo de produção subjetiva acerca das relações com seus colegas:

\begin{abstract}
Você começa a perceber o seu corpo e uma forma diferente... Pô, que dia que você vai parar para pensar o tanto que sua pele é fantástica? Tu não vai.. porque tua pele é algo que teve contigo ali todo o tempo.. Então tu não vai parar pra pensar: "nossa é incrível conseguir sentir as coisas e as pessoas te sentirem!" Isso é incrível e aí não só isso o olfato, música, foi fantástico demais a forma como a gente trabalhou a música.. mas enfim.. você cria um respeito pelo seu corpo e um respeito também pela outra pessoa porque você está o tempo todo em contato com outras pessoas.. (Dinâmica Conversasional)
\end{abstract}

No diário V. expressa encantamento ao estabelecer contato reflexivo com aspectos do corpo aos quais anteriormente não havia dado tanta importância. Expressa estar refletindo sobre as relações no mundo:

Confesso que nunca tinha parado para pensar na importância da pele, não só como órgão físico, mas também como intermediador do contato entre eu e o mundo, os outros seres, os bichos, as plantas o clima, as texturas.(Diário - março)

Em outro trecho, já após a entrada no tema da percepção, que versava sobre as inúmeras percepções que um indivíduo poderia ter acerca de determinado "fato", encontramos nas produções de $\mathrm{V}$. reflexões sobre o contato corporal e sobre as diferentes formas de relação com o contato estabelecidas por diferentes culturas:

Toda a prática de contato e percepção da pele foi muito interessante e sei que é algo raro atualmente, em diferentes culturas e povos o contato e o calor humano é quase impraticável. Estou descobrindo o quão bem isso nos faz. Física e mentalmente. A energia coletiva gerada nesses encontro é perceptível e bem forte. (Diário - ultima semana de março)

No mês de maio encontramos a seguinte anotação no diário de V. após a primeira imersão do Movi-mente Ser: "A procura do meu darma". A própria escrita do termo, na ausência do ' $h$ ' após a letra ' $d$ ' nos indica que o termo por $V$. é desconhecido. 
Perguntamos a ela o que significava aquilo para ela durante a dinâmica conversasional e ela nos responde:

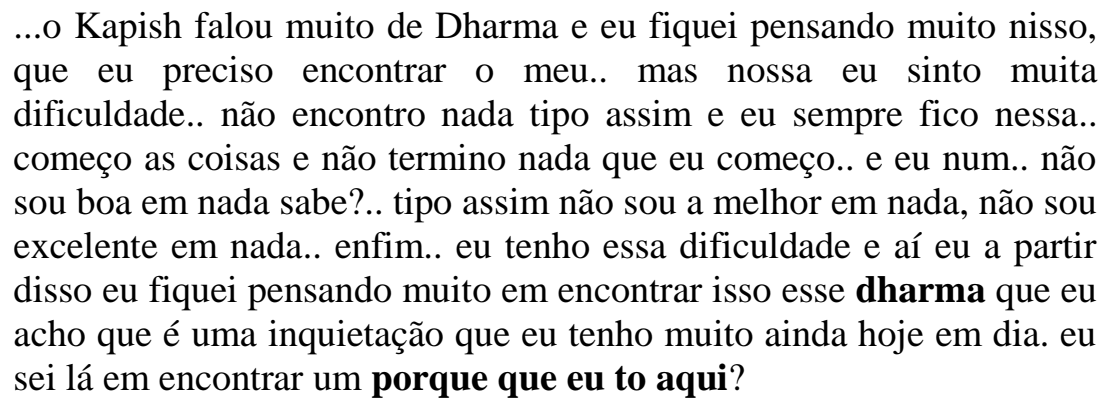

Perguntamos se ela acreditava no que aquilo queria dizer. E ela nos perguntou no que consistia aquele conceito. Nós explicamos a ela o conceito de dharma ${ }^{9}$ provindo de tradições orientais e que no contexto em que estávamos significava: essência, função, uma espécie de qualidade inerente a pessoa e que devesse ser desenvolvida por ela nesta existência. E encontrá-lo representa, de alguma forma, ter encontrado o sentido da própria existência. Algo como a qualidade de uma semente, que retrata a natureza e seu potencial de produzir um determinado tipo de fruto. Ela nos responde: "Eu queria que isso fosse verdade".

Vejamos um trecho onde V. narra o encerramento de uma prática onde possivelmente tenha vivido uma experiência onde acredita ter tido um vislumbre de seu dharma durante uma imersão em maio. Nessa imersão fizemos uma meditação guiada por áudio, o objetivo era construir um caminho de consciência corporal através dos chakras $^{10}$. Vistamos os sete chakras individualmente, haviam instruções que discorriam sobre as características e qualidades próprias de cada um, as características eram narradas no áudio quando nos encontrávamos devidamente concentrado em cada um deles:

Kapish falou: "de volta a casa"... e foi exatamente nesse momento que eu senti isso.. era exatamente isso como se eu tivesse voltando para a consciência universal do mundo e entendendo tudo.. (lágrimas, V. se emociona ao relembrar do vivido) naquele momento eu entendi tudo do que eu sou, do que o universo é.. tudo foi muito claro... (Dinâmica

\footnotetext{
9Dhamma (páli), Dharma (sânskrito). Literalmente, “suporte”, “esteio”, “mantenedor”. É traduzido variavelmente por religião, verdade, doutrina, lei, norma, justiça, retidão, qualidade, virtude, essência, constituinte ulterior, fenômeno, natureza, constituintes da natureza, coisa, objeto da mente, qualidade moral, entidade, etc. No plural, a palavra tem outro significados adicionais: fenômenos (morais, naturais); hábitos, costumes ou comportamentos (bons ou maus); constituições ou elementos do caráter ; eventos, coisas (mentais-emotivas); faculdades (mentais-emotivas). Alguns destes significados são comuns também a algumas filosofias indianas; outros são peculiares ao Budismo. (COHEN, 2004, p. 246).

${ }^{10}$ Rodas de energia do corpo sutil representado nas escolas vedânticas. (FEUERSTEIN,1998)
} 
Conversasional) Procurar uma relação entre esse mundo e o mundo transcendente, a consciência universal . Por que então a existência desse mundo inferior?

Encontramos em seu diário em abril uma espécie de lembrete:

Procurar uma relação entre esse mundo e o mundo transcendente, a consciência universal . Por que então a existência desse mundo inferior?

Vejamos mais dois trechos onde V. expressa suas percepções a cerca do corpomente em um exercício entregue na última semana de aula, onde o professor pediu aos estudantes que simplesmente escrevessem o que era Corporeidade para eles:

Quando nascemos, ganhamos um corpo e uma respiração, temos responsabilidade sobre esse corpo, pois o nosso corpo é a parte do planeta que está mais próxima de nós, assim como nossa respiração é a parte do céu que está mais perto de nós.

A mente humana tem uma relação com a mente da terra, a confusão da mente humana reflete no clima do planeta por isso estamos passando por tantas mudanças e complexidades climáticas.

Em uma de nossas conversas no facebook, falei a ela sobre um instrumento que ainda estava elaborando, mas que seria uma composição sobre quem ela era e num momento criativo, sem compromisso. V. nos enviou por mensagem o seguinte texto:

Só sei que nada sou.

Quem sou eu? Eu não sou ninguém.

Nada sou perto da imensidão, perto do infinito, da consciência Universal. Sou tudo, sou parte de tudo, sou necessário, essencial. Somos o tudo, numa coisa só.

Quem sou eu? Eu sou você, você me é. Fluimos. Surfamos juntos num oceano universal e eterno. Na individualidade do ser.

Eu não sou o que me contorna. Eu sou o que sai de mim, vai além da pele. A pele de tudo que toca, de carícias. De sentir, no superficial do que é profundo.

Eu sou amor da cabeça aos pés. Sou inconstante, imprevisível, eufórica, anciosa, confusa, embrionária. Um nascimento, um despertar, uma descoberta.

Quem sou eu? Nunca saberei. Tudo é cicliquico, tudo flui, caminha e volta. Tudo é mudança, é constante. Eu sou nada, e tudo, de uma vez só.

A partir dos trechos hipotetizamos que V. ao longo desse processo produz sentidos subjetivos diversos significados relacionados à corporeidade e existência.

O sentidos subjetivos relacionados ao corpo estão constituídos pelo encantamento com suas possibilidades. O corpo agora transcende a si mesmo, não é o invólucro que carrega a mente, ele é mente e simultaneamente é a própria terra, é o ar. É um corpo- 
mente, com potencialidade inclusive de transcender a si mesmo. É capaz de ampliar a consciência e captar sua função no organismo cósmico, seu sentido de ser/existir.

Emergem sentidos subjetivos relacionados a diversidade de percepções. O modo como sente-se em relação a forma como lhe é apresentado este conhecimento, dentro de um contexto acadêmico, que desdobra em sua busca espiritual, propicia em V. um flexibilização. A abertura à experiência em relação a diferentes cosmologias e situações atípicas é algo percebido quando V. aceita participar das imersões sozinha. V. foi a única da turma de corporeidade a aceitar o convite e ela não conhecia ninguém do grupo.

Também produz dentro deste processo do curso/projeto e imersões sentidos subjetivos relacionados ao outro, a garota constantemente fala da relação dela com o mundo e com os outros pessoas. Expressa o quão positivo tem sido estabelecer contato com as pessoas, está lhe fazendo bem. Também revela um sentimento positivo em relação ao afeto que é compartilhado neste espaço quando se refere a força da energia coletiva gerada.

Os outros corpos emergem como algo próximo, caloroso e próximo, algo a ser contatado, respeitado, cuidado e a ser conhecido. Por várias vezes em momentos informais, após o término do curso conversávamos sobre relacionar-se. Esse tema surgiu quando, de alguma forma, V. tinha superado seu dilema entre vida profissional e outras atividades. V. expressava certa preocupação em relacionar-se, continuava questionando e refletindo sobre o que seriam relações sustentáveis, aparentemente em uma busca por enxergar o que seriam relacionamentos positivos. Anseio que, possivelmente, mantenha relação com a experiência do relacionamento e separação de seus pais.

Consideramos superado o dilema entre trabalho e atividades coisas que gosta. Percebemos que ao final do ano V. emite uma tranquilidade em seu semblante e sentese integrada a seus afazeres acadêmicos, profissionais e àquilo que the agrada. Consideramos ter relação com a emergência de sentidos subjetivos relacionados a uma clara noção de contribuição social relacionada a seu trabalho. V. passa a sentir suas atividades conectarem-se a seu profundo anseio de contribuir para a preservação da Vida. Essas questões pareciam lhe pesar, e após superadas V. estava mais leve, mais 
brincalhona, seus assuntos e preocupações, apesar de existentes, não transitavam mais por esses assuntos.

Podemos dizer que, segundo nossas hipóteses, V. viveu o que queriamos expressar com a citação de Joseph Campbell no início do trabalho. A garota viveu uma experiência de estar viva e pôde fazer com que a vida exterior se integrasse com sua realidade mais íntima. Ou podemos dizer que foi em direção ao que Rogers (2009) supõe ser uma tendência inerente para a maturação, seguia sua propensão à autorealização.

\subsection{CASO RAÍZA}

É fundamental se sentir, não só sentir o externo, mas sentir o interno.

Raíza

\subsubsection{Caracterização geral de Raíza}

Raíza é estudante de Educação Física na UnB e também cursa Fisioterapia em uma faculdade particular. R. tem 22 anos e durante o momento da pesquisa encontrava-se no penúltimo semestre do curso de Educação Física. Seus pais são separados e R. no início da pesquisa morava com a avó, mãe, tia e irmão. Ao longo do semestre seu irmão foi morar fora do país e a tia também saiu de sua casa.

R. está frequentemente pensando na família, principalmente na saúde de sua avó. Pela intensidade e frequência com que R. fala da família, entendemos que a família configura-se como um alicerce para a jovem. Percebemos que seus cursos de graduação movimentam um forte desejo de cuidar da saúde das pessoas às quais se sente conectada, principalmente à avó e às suas amizades. É uma pessoa que está sempre cercada por poucas, mas boas amigas, amigas às quais ela sempre se refere como melhores amigas.

R. é uma garota alegre está constantemente fazendo piadas e graça com as coisas. A garota julga como necessário ser sempre forte, firme e guerreira. É apaixonada por esportes e ao final de seu curso na Educação Física nos aparece uma pessoa confiante em relação a sua escolha e futuro profissional. 
Observando suas postagens no facebook, cerca três vezes ou mais por semana, a jovem posta fotos de treinos, de competições e de vitorias relacionadas a sua participação em campeonatos de handebol.

Em relação a seu curso de fisioterapia, R. não expressa a mesma paixão do que em relação a Educação Física. Aparentemente isso tem uma relação mais com o espaço social do que com os conteúdos do curso em si. Sua escolha pela graduação em fisioterapia esteve permeada pelo receio de que a Educação Física não lhe desse um retorno financeiro que a permitisse sustentar a vida que deseja. Escolha que também mantém relações com atender um desejo dos pais e parentes, a finalidade é tranquilizálos com relação as ideias de sucesso financeiro concebida por eles.

\subsubsection{Forma de Subjetivação do curso Corporeidade e do Projeto Movi-mente}

A decisão de Raíza em participar no Movi-mente veio de indicação de seus amigos da FEF. A jovem tinha pouca informação sobre o que encontraria no curso. Ela expressa em seu diário num primeiro momento que estava muito ansiosa por estar naquele curso em função dos relatos positivos que os amigos fizeram. Diferente do público geral do curso, R. está cursando uma disciplina optativa do próprio curso.

R. esteve presente praticamente em todas as aulas. Inclusive nos momentos de prova em outras disciplinas. Dentro de sala de aula estava sempre muito focada, o que também é expressado nos diários quando fala sobre as náuseas que sente ao assistir uma aula onde ela acha difícil compreender os conceitos novos apresentados pelo professor.

As tensões que surgem em seu cotidiano, expressas em seu diário, nos mostram como as produções subjetivas de outros espaços participam do processo de subjetivação de R. dentro do espaço do curso. Seus conflitos expressos no diário referem-se a preocupação que ela tem com a saúde de sua avó e tia, ao intenso esforço que faz para manter-se na graduação de fisioterapia e seu dia-a-dia na faculdade particular, seu conflituoso namoro com uma garota que vive em outro estado e sua insatisfação em ter de esconder sua orientação sexual da mãe, irmão e amigos.

Nossa hipótese é de que os sentidos subjetivos que implicam R. no curso, mantenham, num primeiro momento, relações com um desejo de cuidar da família e aprender a relacionar-se de modo a superar seus conflitos. 
Sobre o curso em seu diário, no mês de março, R. escreve sobre uma aula:

É nítido como o que o Kapish falou é verdade, sobre o ser humano estar adormecido, num sono profundo, sem a menor percepção de si e do mundo! Putz e isso é uma merda. São tantas pessoas vivendo no automático... Eu estava vivendo no automático. Cara e isso está tão presente na nossa vida. Minha tia vive assim. A minha namorda está vivendo assim. E isso me preocupa ao extremo. Poxa eu quero ajudar elas, mostrar o que elas tão fazendo e o que elas podiam fazer para melhorar, para terem uma vida mais humana, mais reconhecida. Vou buscar aprender nas próximas aulas formas de aplicar isso nelas. É difícil mas necessário.

Vejamos uma das frases do completamento de frases onde a estudante se expressa sobre o Movi-mente:

12. No Movi-mente... pude me conectar com as outras camadas que existem em mim, explorando todos os sentidos do meu corpo ao extremo. Pude quebrar a rotina de isolamento mental e corporal que estava em mim, e me abrir pra infinidade de sensações e de energias que o universo proporciona. Pude me conhecer mais e me explorar tanto física, quanto emocionalmente. Vivenciei das melhores até as piores experiências. Pude sentir uma elevação do meu eu.

Quando perguntamos se ela indicaria o Movi-mente nos diz que indica para todas as pessoas que conhece, que ainda estão na UnB. Ela fala para todas as pessoas fazerem, quando perguntamos por quais motivos de forma engraçada nos diz que acordou para uma luz. Quando a questionamos o que seria essa luz a estudante traz um tom mais sério em sua voz e comprimindo o rosto assume um tom reflexivo e nos responde:

muda a vida sacou.. muda.. primeiro que muda a vida pra você muda a sua percepção do mundo e de você mesmo. coisas que antes pra você passava despercebido.. sempre valorizei pequenas coisas.. tipo ah ver um beija flor tal.. mas ver o tanto de.... conexão.. o tanto de coisa que tá envolvida naquele ato do beija flor cheirar a beija flor.. tão complexo que é.. e tão necessário fundamental.. dês do beija flor até uma nave espacial.. que a gente manda pra lua... mas de sair do cotidiano repetitivo.. do "caramba eu tenho que estudar.. tenho que fazer as provas.. tenho que fazer os trabalhos.. tenho que casar e ter filho.. tenho que ter uma vida boa" sacou?! sair disso.. pra explorar o sentimento do agora.. o que está acontecendo aqui e agora.. por exemplo, até a parede que ta aqui e até essas cadeiras são incríveis.. sacou? Elas tem um valor energético incrível, não tanto quando uma pessoa que te passa essa energia.. mas é muito complexo.. eu não sei explicar.. deu uma acordada para sentimentos e sensibilidades que estavam totalmente adormecidos.. por exemplo aquele dia do paladar.. de comer.. cara.. as vezes você come a comida lá numa velocidade na sagacidade que você tá e o negócio (a comida) é tão bem elaborado sabe.. um alimento que tem tanta coisa inserido e você deixa passar.. o que pegou pra mim é.. não dá pra deixar passar essas coisas sacou?... é injusto você deixar passar tanta coisa 
complexa e bonita.. assim tipo ah foda-se é meu dia a dia entendeu.. então o corpo acordou... E o que eu falei é que me corpo acordou.. e não só meu corpo mas a consciência de que.. as pessoas tem que acordar o corpo delas.. eu tenho que ensinar isso pras crianças.. eu tenho que ensinar que tipo.. velho.. não desvaloriza o tato.. não desvaloriza a visão.. apesar da visão ser super enganadora.. mas não desvaloriza! a audição.. sacou o olfato..

O curso para R. configura-se como um espaço terapêutico, lugar de dispersão da tensão gerada na semana. A jovem relata uma alegria em seu diário só por saber que naquele dia ela irá a aula, ela fala da possibilidade de aliviar a tensão desenvolvida na semana. Após o relato de um dia difícil ela diz: "logo chegou a aula de Corporeidade, para a salvação de todos." (Diário - março)

O curso/projeto é subjetivado como um espaço que lhe permite sentir o próprio corpo, refletir sobre a vida, relaxar, soltar-se. Também auxilia a conhecer a si mesma em suas limitações, eventuais compreensões e atitudes que a encaminharia a superação de seus conflitos, o que ela continuamente chama de melhorar a si mesma ou evolução. Em síntese, um espaço terapêutico e de redimensionamento de suas percepções a cerca do corpo, descobrindo-o como um corpo dotado de complexidade, sensibilidade e emoção.

\subsubsection{Movimentações na subjetividade}

No caso Raíza não consideramos ter encontrado informações suficientes para a elaboração de uma sólida hipótese sobre recursos subjetivos comumente associados à criatividade, que foi o objetivo da nossa pesquisa. Nos preocupamos com a solidez das hipóteses e expressamos no trabalho apenas aquelas que julgamos ter fundamentação na convergencia dos indicadores que construíamos a partir dos instrumentos corroborando nossas hipóteses. Tudo isto foi feito como forma de não fazer afirmações superficiais. Podemos hipotetizar a existencia de mudanças subjetivas em Raiza que expressam a dimensao funcional da criatividade, porém esse aspecto não foi objeto de estudo especifico por extrapolar os objetivos da pesquisa.

Em certa medida foi possível identificar recursos subjetivos comumente associados à pessoas criativas em Raíza, como a desinibição e auto-confiança mas no processo de construção/interpretação, nos surge com muito mais solidez a emergência de um processo subjetivo que nomeamos de: consciência corporal. Processo esse onde 
percebemos a emergência de sentidos subjetivos relacionados ao corpo e à orientação profissional. Tais sentidos produzidos por Raíza, no futuro, podem participar de um processo facilitador da emergência de recursos que integrem suas configurações criativas.

\section{Consciência Corporal}

No início do estudo dos instrumentos do caso Raíza ficamos um pouco intrigados com o que encontramos. Nossa preocupação residia provavelmente no ingênuo anseio do pesquisador, na aproximação epistemológica até indevida, de ter algo a priori a ser atingido ou percebido. E não apenas isto, durante a produção do primeiro caso nosso olhar vicia-se. Levou tempo para que nos tornássemos receptivos ao que não imaginávamos.

Percebemos que a jovem ao expressar seus conflitos, que majoritariamente ocupam espaço em seu diário, haviam poucas reflexões sobre seu papel na constituição dos conflitos que vivia. Ao escrever sobre as práticas, boa parte do que estava sendo escrito por R. tinha caráter descritivo e pouco reflexivo. Porém ao longo do projeto, vemos em seu diário gradativamente o surgimento de reflexões que remetem a uma perplexidade referente a descoberta do próprio corpo. Nossa hipótese é de que R. inicia um processo de percepção consciente da unidade corpo/mente junto ao desenvolvimento de reflexões sobre a própria sensibilidade.

No início do diário e durante alguns momentos informais, R. falava e registrava sobre sua perplexidade em sentir os próprios sentidos (tato, olfato, audição, visão, paladar) tocando seus objetos (objetos tangíveis, cheiros, sons, cores e formas, sabores). Na dinâmica conversasional, há um momento em que, quando falávamos da disciplina corporeidade e do curso de Educação Física, R. se expressa da seguinte forma:

Meu corpo até março de 2015 era um monte de carne gordura e sangue e é isso.. (e ela ri) sacou?! Era isso.. era isso cabou.. não tinha mais nada além disso.. Depois de março eu vi... (para, reflete, faz um silêncio olhando para o vazio e com uma voz suave).. eu vi $1 \%$ da infinidade do que é o corpo..entende? Até então o corpo era uma capa de gordura, banhas, osso e sangue.. só..

Perguntamos a ela então como ela percebe que o corpo é tratado de maneira geral na Faculdade Educação Física: 
Os professores não exploram essa questão mais.. eu ia falar profunda.. mas não é mais profunda.. não exploram o corpo!.. a galera explora.. as valências físicas tipo: coordenação, agilidade, habilidade fina, e tal.. isso a galera explora..

E em seguida perguntamos a ela, mas o que é o corpo agora? E ela nos responde:

é o que eu falei.. é um infinito de emoções, comunicações e sensações.. de possibilidades.. o corpo é a parte, entre aspas, "material" que consegue te comunicar. te conectar tanto com o material como com o imaterial.. o material é tipo você.. essa mesa aqui.. você sua perna ta aqui.. e tal.. sacou? essa parte mais táctil.. e o imaterial é eu sentir o seu olhar.. ou a sua presença.. aqui na minha frente.. isso eu diria que é mais imaterial..

Após esta fala, com um tom de indignação misturado a um sentimento de agradecimento, por ter desenvolvido uma nova compreensão dentro do curso de Corporeidade, R. expressou o quanto este tipo de concepção corpo-mente é praticamente inexistente dentro de seu curso de graduação. Em seu diário encontramos um escrito que expressa: "O Kapish podia dar esta aula pra todas as pessoas do mundo." O que expressa que a jovem reconhece como valoroso aquilo que o curso veicula.

R. expressava sua perplexidade ao perceber que sentia as coisas, sobre como sentia o vapor da água lhe tocar as mãos ou os cheiros que sentia durante a semana. Também fazia relatos de como seu corpo sentia-se em relação ao conteúdo que estava sendo ministrado.

Nossa hipótese é que ocorre uma produção de sentidos subjetivos relacionados a sua sensibilidade permeados por sentimentos de encantamento com as possibilidades do corpo. Perplexidade, alegria e o simples prazer de sentir são percepções presentes. Há a preocupação com a ausência de espaços como esse que veiculam um conhecimento importante para o desenvolvimento humano.

Vejamos no diário trechos que corroboram com nossa produção teórica acerca do processo de $\mathrm{R}$. e a produção de sentidos subjetivos relacionados a percepção e sensibilidade:

Segundo estudos só conseguimos usar, no máximo $20 \%$ da nossa percepção. Ou seja, $80 \%$ das coisas que acontecem nos nem percebemos, e nem temos IDEIA do que rola. Isso é muito doido. Imaginar o tanto de coisas que estamos deixando passar. É algo que me assusta, me dá medo, preocupação... Não se perceber, deixando o imaterial de lato e focando só no material... (março) 
R. Fala sobre um momento de partilha entre os estudantes após uma prática, ela se impressiona por conhecer outros estudantes logo na segunda semana de aula:

Cara, olha que louco, olha como é imediato essa influência! Quando as pessoas se entregam e acessam os seus sentidos, o seu interior elas se abrem e abrem a cabeça! Muito massa! (março)

R. reflete sobre a percepção e o automatismo do sentir:

Sobre esse incômodo de ver as pessoas em um automatismo cego, deixando de lado tanta coisa essencial, sentir, sem ser minímamente sensível. (março)

Me incomoda ver o tanto que a sociedade não apresenta mais a sensibilidade humana. (abril)

Surgem outros elementos no Completamento de Frases:

6. Meu corpo... é meu abrigo, minha conexão com o mundo exterior, minha fortaleza, minha força.

17. Desejo... vivenciar muitas coisas ainda, conhecer o mundo, conhecer pessoas, conhecer sensações e sentimentos. Desejo ajudar muitas pessoas, criar algo que marque e melhore a vida de muitos.

18. Corporeidade... é um aprendizado profundo sobre si, seu corpo e suas sensações conectados com o mundo e todo o universo ao redor.

60. Considero que posso... fazer coisas incríveis utilizando mecanismos simples. Posso resgatar esse olhar mais sensível com relação ao mundo mostrando como utilizar melhor seu corpo.

Nossa hipótese é de que os sentidos subjetivos produzidos por R. acerca do corpo, dentro deste espaço, começam a ser permeadas por um sentimento de que há no corpo algo além do físico. A estudante agora concebe a existência de um aspecto imaterial. Quando pergunto se seria algo subjetivo, nos responde que sim com exaltação e agradecimento como que se tivéssemos auxiliado ela a encontrar a palavra apropriada.

Este conhecimento novo, inclusive tem reverberações no que R. declarou como sendo momento mais intenso dentro do curso de Educação Física, o estágio onde deu aula para crianças do sétimo e oitavo ano. Naquele momento, segundo ela, havia compreendido o que de fato estava fazendo ali.

Hipotetizamos que a produção de sentidos subjetivos relacionados ao corpo-mente favoreceu a produção de novos sentidos subjetivos relacionados ao trabalho como professora de educação física. A estudante, que já tinha um forte sentimento de responsabilidade social integrado ao trabalho, agora percebe seu trabalho de uma forma 
mais ampla. Passou a se ver para além de alguém educando um corpo num sentido da performance, mas efetivamente cuidado de seres de forma integral e educando para a integralidade. Vejamos um trecho da dinâmica conversasional onde ela fala sobre o que aprende em seu curso:

Tipo.. a gente aprende a ensinar um aluno (a fazer) uma estrelinha..(movimento corporal) aprender pra ensinar determinado esporte.. isso a gente aprende. mas a gente não aprende a sensibilidade que esse corpo tem.. (aqui a garota fala com a voz firme e série.. não está de brincando como tem o costume) Tipo não aprende a comunicação.. não aprende a importância do toque.. não aprende isso.. te falo assim sem dúvidas.. tem tipo (a jovem da um exemplo): ah o menininho arremessa a bola e tem várias formas de fazer ele arremessar a bola, é assim.. é assim na Educação Física!

Vejamos os trechos usados como indicadores para hipotetizarmos que produção de sentidos subjetivos, relacionados a unidade corpo/mente, altera a forma como $\mathrm{R}$. posiciona-se diante de sua futura profissão.

22.O trabalho... deve ser algo extremamente prazeroso e com algum valor social, que signifique algo de fato na vida de alguém.(Completamento de frases)

37.Minhas aspirações são... ter um emprego de sucesso, ensinar crianças sobre seus corpos e suas mentes, curar aqueles que tem dor, motivar as pessoas a seguirem com seus sonhos. (Completamento de frases)

60. Considero que posso... fazer coisas incríveis utilizando mecanismos simples. Posso resgatar esse olhar mais sensível com relação ao mundo mostrando como utilizar melhor seu corpo. (Completamento de frases)

70.0 estudo... é algo que deve te fazer evoluir, crescer, que deve mudar sentimentos ou sensações dentro de você. $O$ estudo não é isso que se aprende na faculdade (na sua grande maioria). O estudo é a reflexão e a prática das questões que te perturbam ou que te instigam ou que sejam fundamentais pra sua existência. E a corporeidade faz isso no nível mais profundo do ser. (Completamento de frases)

E na composição:

Sou uma pessoa que quer ensinar as gerações, às crianças e até os idosos, a usarem seus corpos e não apenas estarem neles. Quero mostrar a infinidade de experiências que eles podem ter sabendo explorar o corpo que habitam. Quero que valorizem os sentidos humanos e que estejam aberto às mais diversas experiências. Quero ensinar e despertar a sensibilidade física e emocional com o mundo, pra que não sejam um monte de alienados que estão esperando a morte chegar. Quero mostrar o tanto que essa vida é 
incrível, basta mexer seu corpo e usá-lo da melhor forma pra isso. (Composição)

Os sentidos subjetivos produzidos por R. em relação ao próprio corpo favorecem uma postura investigativa e reflexiva diante do corpo e de si, de sua constituição complexa. Auxilia a remover-lhe a obviedade e torna um mistério a ser investigado. Para nós essa postura favorece, em sua subjetividade, um processo de questionamento acerca desta complexidade e uma abertura para vivenciar a própria experiência ou um ímpeto de autoconhecimento (ROGERS,2009).

É relevante ressaltarmos que Mitjáns Martínez (2002), em seu trabalho sobre a criatividade no trabalho de professores, aponta como um fator favorecedor de um fazer criativo: a clara orientação acerca do futuro profissional dos indivíduos pesquisados. Sendo assim, esta clareza que a aluna encontra acerca de sua atuação no campo profissional também pode ser um aspecto participante de futuras configurações criativas associadas ao trabalho docente.

\subsection{ANÁLISE INTEGRATIVA DOS CASOS}

Foi valoroso perceber o desenvolvimento de dois tipos de pessoas que frequentemente encontram-se no espaço do curso corporeidade, alunos de vários cursos que já possuem um interesse específico relacionado com os objetivos do curso, como no caso de Valkyria. E alunos que, como Raíza, cursam a disciplina sem ter necessariamente uma expectativa clara acerca do que encontrarão no curso. Situação que geralmente acontece com estudantes da educação física que necessariamente tem que escolher disciplinas optativas.

Para nós, os aspectos emergentes associados à criatividade em Valkyria se tornam mais evidentes, hipotetizamos que isto ocorra em função das diferentes motivações de estudantes em relação ao curso. V. expressa recorrentemente uma busca consciente na direção do autoconhecimento, um processo de reflexão sobre si, sobre a existência, sobre o outro, sobre as relações. R. cursa uma disciplina que foi indicada por seus amigos de educação física.

No caso Valkyria assim como no caso Raíza, nós encontramos esta perplexidade e descoberta referente a sensibilidade do corpo. Porém em V. seu olhar está predominantemente centrado em aspectos subjetivos. V. expressa estar realizando uma 
investigação sobre sua subjetividade, o que ela sente; como e por que ela se sente de determinada forma em relação às coisas da vida.

Enquanto isso percebemos que R. está descobrindo que o corpo possui subjetividade. No diário de R. e durante nossas dinâmicas conversasionais, R. se declara conhecendo a si mesma e inclusive refletindo sobre si como nunca havia feito antes. Mas suas reflexões e perplexidades predominantemente consistem em narrar sobre quão fantástica é a capacidade do corpo sentir, de emocionar-se, de a partir de experiências que usam os sentidos perceber a existência de uma mente no corpo.

Como ela diz, ela percebe que o corpo é mais do que carne, gordura e ossos. R. não está, por exemplo, como em V. predomina, questionando seu caráter de sujeito em relação às coisas que lhe acontecem.

R. está concebendo este corpo complexo, que sente e que emociona-se, que age tanto conscientemente como inconscientemente, e em nossa hipótese, sua produção de sentidos subjetivos relacionados ao corpo cria condições favoráveis para um processo de abertura a si mesma, pois está concebendo que o que ela pensava e gostaria de ser está longe do que efetivamente é. O corpo-mente, espaço que antes era tido como algo dado, agora está se torna um mistério destituído de obviedade.

Para V. o corpo já é um complexo mistério a ser desvendado e conhecido por ela mesma, a fim de satisfazer sua necessidade de estabelecer uma relação satisfatória com o mundo. Para R. o corpo é objeto de estudo do curso de graduação, já é algo que possuía uma sólida produção conceitual.

R. de alguma forma é surpreendida em relação ao corpo enquanto $V$. encontra o que já estava buscando, uma oportunidade para se conhecer. Não houve diferença em relação as duas estudantes a nível de envolvimento e compromisso com o curso, pois ambas estavam presentes e empolgadas. Mas existia uma familiaridade maior de V. em relação aos aspectos teóricos do curso e aos objetivos da mesma.

Ao final do processo de R., nos parecia que a jovem estava conseguindo conceber a proposta do curso: conhecer o mistério para além do corpo óbvio, que alimenta em R. uma vontade de se autoconhecer. Em seus relatos, ao final do curso, começamos a ver em R. pela primeira vez uma expressão autocrítica. Também se expressa um reconhecimento das próprias qualidades indicando um aumento da auto-estima, coisas 
que inexistiam durante a maior parte do processo. Portanto possivelmente teríamos a oportunidade, caso o curso se estendesse, de perceber e fundamentar em R. a emergência de processos subjetivos que percebemos emergir em $\mathrm{V}$.

Este processo em R. surge na medida em que ao remover a obviedade de seu corpo, concebe-o complexamente, abre-se a possibilidade de continuar em busca de processos semelhantes ao Movi-mente. Amplia-se o poder de encontrar formas de superar seus padrões mecânicos, algo que ela expressa no seu documento de autoavaliação.

O curso/projeto é subjetivado de forma diferente pelos sujeitos. Apesar de ambos os casos encontrarmos uma concepção terapêutica do espaço, ainda assim assume uma característica singular para os sujeitos.

Os por quês e os para quês das duas em relação a participação no curso/projeto diferenciam o processo de subjetivação do curso e implicação no mesmo. R. está em busca de ampliar seu leque de conhecimentos que lhe permitam cuidar de sua família, de seus futuros alunos e pacientes no que se refere ao curso de Fisioterapia. Enquanto o que implica V. no curso é conhecer-se para libertar-se de uma condição indesejável.

Percebemos que no diário, em momentos informais e dinâmicas conversasionais com R. ela faz muito mais constatações sobre os conhecimentos novos que adquire sobre o corpo/mente, enquanto V. está reportando suas constatações acerca daquilo que sente enquanto vivencia o curso/projeto. V. parece esta predominantemente falando de sua vivência do projeto, enquanto $R$. está predominantemente fazendo constatações sobre os conhecimentos adquiridos em relação ao corpo.

A experiência do curso vai produzindo mudanças na subjetividade em função de configurações subjetivas previamente constituídas na pessoa e pela forma como curso é vivenciado e subjetivado por ela. Estas mudanças, portanto, referem-se a processos diferentes em indivíduos distintos.

A emergência dos recursos associados à criatividade, que inicialmente focamos neste trabalho, aparece como uma possibilidade ampliada quando a aproximação da pessoa ao curso/projeto está atrelada ou em sintonia com sua aspiração intima e objetivo próprio: autoconhecimento. Também quando no decorrer do mesmo produzem-se sentidos subjetivos em relação a esse aspecto. 
Em V. por exemplo, as mudanças que percebemos estão ligadas aos processos subjetivos relacionados à criatividade que focamos e desenvolvem-se principalmente a nível de reflexão sobre si, que potencializa-se por estar atrelado a sua vontade de se autoconhecer, em sintonia com o objetivo do curso. No entanto apareceram também outros recursos subjetivos associados à criatividade como novas configurações da motivação profissional como vimos no caso $\mathrm{R}$.

Tudo isto corrobora inferir, nos sujeitos estudados, uma relação entre corpo, mudanças na subjetividade e criatividade. Os sujeitos implicaram-se numa experiência da corporeidade, que constituiu um espaço de produção de novos sentidos subjetivos. Esses expressaram-se em mudanças nas configurações subjetivas que, entre outros aspectos, implicaram o desenvolvimento, ao menos incipiente, de recursos subjetivos associados à criatividade. 


\section{IMPERMANENTES CONSIDERAÇÕES FINAIS}

Como vimos neste trabalho, foi possível articular uma relação, que não é linear e nem causal, entre Corporeidade, Subjetividade e Criatividade. Observamos como que uma experiência em um espaço, onde organizam-se várias experiências com o corpo com o objetivo de autoconhecimento, tem desdobramentos na subjetividade de seus participantes, favorecendo a emergência de recursos subjetivos associados à criatividade.

A presente pesquisa torna-se relevante ao passo que nos permite ampliar nossas compreensões sobre de que forma o trabalho com o corpo, em uma perspectiva complexa, multicultural e espiritual, propulsionada pelo campo da Corporeidade, pode ter impactos no desenvolvimento da subjetividade favorecendo potencialmente uma futura expressão criativa.

A Teoria da Subjetividade nos alerta para ao fato de que nas nossas relações com o mundo e com nós mesmos participam de nossas configurações subjetivas. Desta forma, quando pensamos em saúde, bem-estar e educação dentro da teoria pensamos em recursos subjetivos capazes de auxiliar o indivíduo em sua trajetória pela vida. Auxiliam em uma vida que, longe de ser perfeita, pode ser vivida com dignidade e com um senso de satisfação maior do que o de insatisfação. Quais configurações singulares participariam da constituição de uma pessoa que se sente realizada neste mundo?

Apesar dos humanistas não terem formulado a pergunta da maneira como formulada no parágrafo acima, a intenção de seu trabalho nos parece ser guiado pela vontade de dar resposta a ela. Os humanistas não só deram resposta, como também atribuíram às pessoas realizadas a característica de serem criativas, correlacionando criatividade a uma série de outros comportamentos comumente associados ao bem estar psicológico.

Então uma pergunta que imaginamos que os educadores e pesquisadores que assumem a subjetividade façam, ou deveriam fazer recorrentemente, a si mesmos seja: como criar condições que oportunizem a emergência de recursos subjetivos favoráveis ao desenvolvimento integral dos seres humanos? Quais condições ou situações podem ser didaticamente organizadas com a intenção de favorecer o desenvolvimento de determinados recursos subjetivos? Como, de forma intencional, organizar situações que 
sejam favoráveis ao desenvolvimento de processos subjetivos como a autoconfiança, paciência, desinibição, coragem, resiliência ente outros, muitos deles favorecedores da criatividade?

O presente trabalho é um passo modesto em direção à compreensão da relação corpo-subjetividade. Relação que nos leva a uma dessas criativas e sofisticadas formas de pensar e atuar em sala de aula, em um processo educativo formal do ensino superior, onde o corpo pode ser utilizado como via para o desenvolvimento da subjetividade.

O corpo, que a todo o momento somos e estamos, que simplesmente se encontra em todos os lugares, escolares e não-escolares, pode ser concebido como, dependendo da forma como nos é apresentado e experienciado, um espaço propício para o desenvolvimento da subjetividade. O corpo pode ser concebido como uma matriz pedagógica multi e transdisciplinar. É capaz de nos oportunizar, de forma mais íntima, revisitarmos aquilo que conhecemos e nos espantarmos com aquilo considerado óbvio, que ainda não foi pensado e sentido, produzindo novos saberes sobre nós mesmos e os diversos outros.

Neste espaço o corpo não surge como uma máquina que pode atingir alta performance. Não surge como algo que precisa estar em uma forma pré-determinada para atender uma estética hegemônica e nem mesmo algo a ser usado para atingir uma saúde estritamente fisiológica. Mas torna-se um complexo organismo capaz de revolucionar a subjetividade daqueles que se tornam presentes em Si mesmos (SOUSA, 2009-2010).

Como pesquisadores o que mais nos toca ao longo do trabalho é o poder das unidades simbólico-emocionais, o que nos fez pensar em uma microfísica da ação. O impacto da emergência de novos sentidos subjetivos pode ser capaz de atribuir ao olhar e existência da pessoa um brilho inarrável, em um instante pode tornar-se leve aquilo que outrora lhes pesava.

O corpo integra uma subjetividade que pode suavizá-lo e tonificá-lo ou carregálo e danificá-lo. Somos levados a pensar nos corpos humanos que habitam a Terra, que em sua unidade, são uma espécie de tecido móvel que envolve e move-se ao redor do corpo terráqueo. Estes corpos humanos, portadores de subjetividade individual, constituintes e constituídos da e na subjetividade social também deterioram o próprio 
corpo/casa ao perceberem-se separados e superiores aos diversos outros e à natureza. Tal crença pode torná-los passíveis de serem inescrupulosamente explorados e desrespeitados. Como também pode portar uma subjetividade que favorece a regeneração de nossas relações com nós mesmos e com o Todo, conforme estabelecemos vínculos sensíveis e afetivos com os mesmos.

Tentar compreender a subjetividade, seja ela individual, seja ela social, é tentar compreender quais crenças, emoções, pensamentos, sentimentos, percepções, individuais e compartilhadas são constituídas dentro de um contexto histórico-cultural. Como podem estar participando de nossos movimentos corpóreos individuais e coletivos, sem que inclusive tenhamos a consciência de que ou por que estamos agindo. E pior, inconscientes do quê ou a quem servimos através de nossas ações.

A Epistemologia Qualitativa realmente nos apresentou um desafio. A produção teórica que ela demanda exige bastante do pesquisador, é um processo ativo e criativo. Como processo criativo não funciona na mesma cadência que o ato reprodutivo. No lugar de pesquisadores iniciantes tínhamos dúvidas em relação à forma como expressar nossas ideias dentro da teoria. Nos parece que ao longo do tempo a experiência vai tornando o processo menos dolorido, na medida em que nos familiarizamos com sua forma.

Outro fator que nos chama a atenção é perceber que a pesquisa é um momento subjetivo do pesquisador. Nosso olhar provavelmente viciado pelo primeiro caso, custou a se tornar receptivo ao o inesperado quando fomos trabalhar no segundo caso. Agora, no instante que concluímos o texto, continuamos a revisitar as informações produzidas em campo, e continuamos a fazer associações, análises-interpretativas e novas hipóteses continuam a surgir. Agora já somos orientados por outros interesses, que não são mais os pautavam o início desta pesquisa.

Enquanto pesquisamos nos transformamos. No instante em que estudamos algo temos nossa subjetividade impactada pelas relações que estabelecemos com a temática e nosso momento de vida. Desenvolvemos novos interesses, concebemos novas possibilidades, nos relacionamos com a pesquisa e com os sujeitos de forma mutante. Desta forma o observado está em movimento da mesma forma que o observador (pesquisador). Na reconfiguração da sua subjetividade, tem seu objeto de estudo transformado. O interessante é poder perceber que a Epistemologia Qualitativa possui 
um dinamismo que, por si, favorece um processo de produção cientifica complexo e transdisciplinar.

Ainda há muito o que ser pesquisado, nesta pesquisa demos pequenos passos em busca de compreender a relação corpo e subjetividade. Alertamos para uma certa urgência que temos em implantar projetos como o curso/disciplina em diferentes espaços formais e não formais, não apenas no ensino superior e não apenas no curso de Educação Física. Favorecer um processo onde, a partir do corpo, somos capazes de conceber a nós mesmos de uma forma nova e principalmente mais humana.

Conforme desenvolvermos uma compreensão de que somos corpos portadores de subjetividade, portadores de crenças e emoções, constituídas numa relação com o tempo histórico e em uma determinada cultura; ao percebermos a constituição singular de cada ser humano, nos destituímos da noção de normalidade e da obviedade de nossa etnocêntrica forma de existir e habitar o planeta. O que nos amplia a faculdade de nos tornarmos abertos e tranquilos em um diálogo com o diferente e até mesmo com aquilo que nos é absurdo. Diálogo sem o qual seremos incapazes de transformar nossas relações e muito menos de abrir espaço para o novo, para a criatividade.

É preciso destituir o corpo de sua moderna obviedade, é preciso que espaços como o curso e o projeto, apresentados nesta pesquisa, sejam cuidadosamente pensados. Por exemplo, a partir de uma perspectiva da criação de políticas públicas que nos garanta acesso a uma forma transformadora de concebermos a nós mesmos e o mundo. Não apenas no sentido de inserção de um componente curricular, mas como um princípio que deve orientar processos educativos comprometidos com o bem-estar planetário.

É necessário recordamos que todos os processos educativos, que se configuram como um verdadeiros processos de relação, são terapêuticos. A terapia infelizmente, pela forma como se desenvolveu a psicologia, contribuiu para que popularmente fosse associada a patologias. Habita na subjetividade social dominante a compreensão de que apenas se busca práticas terapêuticas quando de alguma forma se acredita estar doente. Ao associarmos e necessidade de terapia à doença, nos esquecemos de nos terapeutizarmos acerca de questões cotidianas como a questões relacionadas a escolha profissional e relacionamentos familiares. 
Nos parece que este seja um delicado trabalho de criar espaços de alto nível, como o Movi-mente, e neste exato momento é um desafio. Da mesma forma que surgem atividades aparentemente interessantes e de positivo valor para aqueles que o praticam, também surgem algumas iniciativas um tanto quanto estranhas, charlatãs. A epistemologia qualitativa pode nos servir como um instrumento de observação qualitativa em relação a essa iniciativas.

Ao nos aproximarmos da temática percebemos o quanto o tema está em voga; o quanto emerge com grande intensidade um mercado no campo dos cursos e terapias que se desdobram a partir de visões que integram corpo, visões do oriente, novas interpretações da física quântica e psicoterapias corporais. A necessidade de produzirmos propostas de alto nível nos soa como um ato de cuidado para com os seres humanos e força propulsora de pesquisas neste campo.

Em um curso de Educação Física, por exemplo, pode ser interessante perceber como se encontram as subjetividades daqueles que passam por este curso, pode ser uma forma de compreendermos o impacto de nosso currículo, que pode estar oculto para os próprios docentes.

A partir da pesquisa realizada consideramos a necessidade de novas pesquisas como, por exemplo: pesquisar o impacto de espaços como o estudado na subjetividade de pessoas completamente pragmáticas e totalmente apáticas em relação ao espaço e sua proposta; acompanhar mais sujeitos de pesquisa e durante tempos maiores de envolvimento com o projeto; pesquisar espaços que se propõem a trabalhar o tema da Corporeidade, mas a partir de diferentes abordagens. Esta foi a que nos chamou mais a atenção, pois a forma espiritual e multicultural com que a Corporeidade é trabalhada neste projeto específico não é hegemônica, é uma especificidade. Por mais que haja uma leveza na forma como surge, o curso está fortemente marcado por uma visão oriental de corpo-mente, cosmos e desenvolvimento. Quais impactos teriam um curso que estivesse destituído desta perspectiva oriental transcendental?

O universo teórico/filosófico por detrás do projeto é muito importante. Para nós é o sentido que permeia as coisas que estão sendo feitas é o que faz com que as movimentações não sejam mecânicas. É o que faz com que o yoga, por exemplo, não seja uma ginástica, é o que faz com que a meditação não seja uma espécie de droga. 
As práticas, destituídas de uma visão poderiam se tornar mais um tipo de escravidão, mais uma simples forma de fuga do cotidiano, o que em hipótese alguma pode ser considerado, como sendo o objetivo de tais práticas. Tendo em vista a crescente a ânsia pelas tecnologias do Ser, através do reconhecimento de seus impactos neurofisiológicos, este tema é de extrema relevância. Populariza-se o acesso a essas tecnologias, mas ao mesmo tempo teme-se o retorno ao trevoso período medieval, ao aproximar-se de uma perspectiva filosófica radicalmente diferente da que concebemos no cotidiano ocidental e que por vezes preconceituosamente enquadramos em nossa restrita concepção científica do religioso. Com isso distorcendo suas bases filosóficas e epistemológicas.

Abrir-se à Corporeidade em uma perspectiva multicultural é embarcar em uma criativa viagem rumo ao incerto, ao misterioso. É abrir-se curiosamente às diversas culturas produzidas pela corporeidade ao longo de sua existência para relacionar-se com o mundo. Neste caminho, ao visitarmos a nós mesmos, em experiências inusitadas, ampliamos nossas chances de produzir sentidos subjetivos que dão à vida qualidade essencial ao bem viver: Sentido.

No desdobramento subjetivo destas experiências podemos passar a viver encantados pela criatividade que permeia toda a vida. Criatividade que tem intensificada sua expressão quando nos presentificamos no corpo e nos experienciamos, indagamos e refletimos de forma destemida, sincera e espantosa acerca de questões básicas como: Quem somos nós? De onde viemos? Por que e para que viemos? Para quem vivemos? Para onde vamos?

Pensar a educação do corpo é permitir que o corpo de cada um, sem medo, produza respostas às perguntas que sintomaticamente lhe inquietam. Perguntas e respostas que nos surgem quando paramos e nos observamos. É o início do processo de conhecer e produzir o conhecimento, inquietar-se ou espantar-se ao ser encontrado por uma ideia ou lembrança. Encontrar nosso próprio corpo é um encontro criativo com nós mesmos, conscientizarmo-nos de que nos emocionamos e temos sentimentos, de que operamos para além de nossa consciência local é caminho para um viver sensível e criativamente consciente.

Reconhecer e legitimar o sensível e o emocional em si mesmo, reconhecer a singularidade da própria história em si mesmo e reconhecer isto no outro, é um passo 
em direção ao respeito e compassividade diante da complexa expressão humana e, portanto, da Vida; é tornar lícita a qualidade criativa da natureza e se tornar receptivo à sua expressão; é deixar o mistério nos sussurrar aos ouvidos a poesia que da vida ao mundo. 


\section{REFERÊNCIAS}

ALENCAR, E. M. L. S.; FLEITH, D. S.; BRUNO-FARIA, M. F. A medida da criatividade: possibilidades e desafios. Medidas de criatividade: teoria e prática, $\mathrm{p}$. $11-34,2010$.

BARROS, Laura P. de. O corpo em conexão: sistema Rio Aberto. Niterói: Ed. UFF, 2008.

BRITO, Marcelo de. A construção do sentimento de unidade: desdobramentos de uma abordagem corporal atípica no desenvolvimento humano. 2013. x, $166 \mathrm{f}$. Tese (Doutorado em Ciências do Desporto)—Universidade de Trás-os-Montes e Alto Douro, Vila Real, 2013.

CAPRA, Fritjof; FYFIELD, John A. Uncommon wisdom: Conversations with remarkable people. New York: Simon and Schuster, 1988.

; EICHEMBERG, Newton Roberval. O tao da física: um paralelo entre a física moderna e o misticismo oriental. Cultrix, 1987.

A teia da vida: uma nova compreensão científica dos sistemas vivos. Editora Cultrix, 2006

CAPURSO, Viviana; FABBRO, Franco; CRESCENTINI, Cristiano. Mindful creativity: the influence of mindfulness meditation on creative thinking. Frontiers in psychology, v. 4, 2013.

DELORS, Jacques et al. Educação: um tesouro a descobrir. São Paulo: Cortez, 1998.

DING, Xiaoqian; TANG, Yi-Yuan; TANG, Rongxiang; POSNER, Michael. Improving creativity performance by short-term meditation. Behavioral and Brain Functions, v. 10, n. 1, p. 9, 2014.

DYCHTWALD, Ken. Corpomente: uma síntese dos caminhos do oriente e do ocidente para a autoconsciência, saúde e crescimento pessoal. São Paulo: Summus, 1984.

ELIADE, Mircea. Yoga, imortalidade e liberdade. Palas Athena, 1996. 
FELDENKRAIS, Moshe. Consciência pelo movimento. Grupo Editorial Summus, 1977.

FELDMAN, David Henry; CSIKSZENTMIHALYI, Mihaly; GARDNER, Howard.Changing the world: A framework for the study of creativity. Praeger Publishers/Greenwood Publishing Group, 1994.

FEUERSTEIN, Georg. A Tradição Do Yoga. Editora Pensamento, 1998.

FREIRE, Paulo. Pedagogia do Oprimido. Rio de Janeiro: Editora Paz e Terra, 1981.

Pedagogia da autonomia: saberes necessários à prática pedagógica. São Paulo: Paz e Terra, p. 165, 1996.

FREUD, Sigmund. Estudos sobre a histeria (1893-1895). . Obras Psicológicas

Completas de Sigmund Freud. Rio de Janeiro: Imago, v. 3, 1996.

GONZÁLEZ REY, Fernando. Epistemología cualitativa y subjetividad. EDUCEditora da PUC-SP, 1997.

Pesquisa qualitativa em Psicologia-caminhos e desafios. Cengage Learning Editores, 2002.

Sujeito e subjetividade: uma aproximação históricocultural. Pioneira Thomson Learning, 2003.

O social na psicologia e a psicologia social. Editora

Vozes, 2004.

O valor heurístico da subjetividade na investigação psicológica. Subjetividade, complexidade e pesquisa em psicologia, p. 27-52, 2005a. ; SILVA, Marcel Aristides Ferrada. Pesquisa qualitativa

e subjetividade: os processos de construção da informação. Cengage Learning, 2005b.

Subjetividade e saúde: superando a clínica da patologia. São Paulo: Corteza, 2011. 
GOLEMAN, Daniel. A mente meditativa: as diferentes experiências meditativas no oriente e no ocidente. Atica, 1997.

GOSWAMI, Amit; REED, Richard; GOSWAMI, Maggie. O universo autoconsciente. São Paulo: Aleph, 2007.

Criatividade quântica: como despertar o nosso potencial criativo. São Paulo: Aleph, 2008.

GROF, Stanislav; BENNET, Hal Zina. A mente holotrópica: novos conhecimentos sobre psicologia e pesquisa da consciência. Rio de Janeiro: Rocco, p. 95-114, 1994.

- Psicologia do futuro: lições das pesquisas modernas da consciência. Niterói, RJ: Heresis, 2000.

HORAN, Roy. The neuropsychologial connection between creativity and meditation. Creativity Research Journal, V. 21, n 2-3, p. 199-222, 2009.

HART, William. Meditação Vipassana: A Arte de Viver Segundo SN Goenka. Pariyatti, 2012.

IYENGAR, Bellur Krishnamachar Sundararaja. A árvore do Ioga. Globo, 2001.

JECUPÉ, Kaka Werá. A terra dos mil povos: história indígena brasileira contada por um índio. Editora Peirópolis, 1998.

KAUFMAN, James C.; BEGHETTO, Ronald A.; POURJALALI, Samaneh. Criatividade na sala de aula: uma perspectiva internacional. Criatividade e aprendizagem: caminhos e descobertas em perspectiva internacional. São Paulo: Edições Loyola, p. 53-72, 2011.

LOWEN, Alexander. Prazer: Uma abordagem criativa da vida. Grupo Editorial Summus, 1970.

MASLOW, Abraham Harold. Introdução à psicologia do ser. Livraria Eldorado Tijuca Ltda., 1968.

MARTÍNEZ, Albertina Mitjáns. BRAGOTTO, Denise; GIGLIO, Zula; WECHSLER, Solange (orgs.). Da criatividade à inovação. Vygotsky e a criatividade: novas leituras, novos desdobramentos. p. 11-38. Papirus, 2009. 
; TACCA, M. C. V. R. Criatividade no trabalho pedagógico e criatividade na aprendizagem: uma relação necessária. Aprendizagem e trabalho pedagógico, p. 69-94. Alínea, 2008.

A criatividade na escola: três direções de trabalho. Linhas Críticas, v. 8, n. 15, p. 189-206, 2002.

Criatividade, personalidade e educação. Papirus, 1997.

MENEZES, Carolina Baptista; DELlAGLIO, Débora Dalbosco. Por que meditar? A experiência subjetiva da prática de meditação. Psicologia em Estudo, v. 14, n. 3, p. 565-573, 2010.

MORIN, Edgar. O método vol. 1-a natureza da natureza. Porto Alegre: Sulina, 2002.

A cabeça bem feita. Rio de Janeiro: Bertrand Brasil, p. 99, 2000. Introdução ao pensamento complexo. Porto Alegre: Sulina, 2007.

OSHO, Bhagwan Shree Rajneesh. Criatividade: liberando sua força interior. São Paulo, 1999.

PIERRAKOS, John. Core Energetics. Mendocino, California: Life Rhythm, 1987.

PRIGOGINE, Ilya. As leis do caos. São Paulo: Editora UNESP, 2002.

MERLEAU-PONTY, Maurice. Fenomenologia da percepção. 1999.

RAHULA, W. A. O Ensinamento de Buda. Lisboa, Estampa, v. 107, p. 132, 2005.

REICH, Wilhelm. A função do orgasmo. Dom Quixote, 1978.

ROGERS, Carl Ransom. Liberdade de aprender em nossa década. Martins, 1986.

.Tornar-se pessoa. Livraria Martins Fontes, 2009.

ROLLO, May. A coragem de criar. Rio de Janeiro: Nova Fronteira, 1982.

MOSCOVICI, Serge. Sociedade contra natureza. Petrópolis: Vozes, 1975.

SANTOS, Boaventura de Sousa; MENESES, Maria Paula. (Orgs.) Epistemologias do Sul. São Paulo: Editora Cortez. 2010. 
SANTOS, NETO. Por uma educação transpessoal: A ação pedagógica e o pensamento de Stanislav Grof. Rio de Janeiro: Lucerna, 2006.

SCHULTZ, Duane P. SCHULTZ Sydney Ellen. Teorias da personalidade. São Paulo: Cegage Learning, 2008.

SHELDRAKE, Rupert. A Presença do Passado: ressonância mórfica. Lisboa: Instituto Piaget; 1996.

SOUZA, José Antunes. Motricidade Humana: um nome ou um programa de vida? In: FIEP BULLETIN, 79(1), 2009-2010, pp 46-55. [Acesso em 25 março 2016]. Disponível em: http://www.lusosofia.net/textos/sousa_jose_antunes_motricidade_humana_um_nome_o u_um_programa_de_vida.pdf.

TORO, Rolando. Biodanza. Editorial Cuarto Propio, 2008.

VYGOTSKY, Lev. Imaginação e criatividade na infância. São Paulo: Ática, 2009.

WESCHLER, Solange Muglia. Criatividade: descobrindo e encorajando. Campinas: Editorial Psy, 1993.

WILBER, Ken. O espectro da consciência. São Paulo: Cultrix, 1989. Uma breve história do universo. Rio de Janeiro: Nova Era, 2001. Uma teoria de tudo. Presses Université Laval, 2003. Espiritualidade integral: uma nova função para a religião neste início de milênio. São Paulo: Aleph, 2006. 
ANEXOS

\section{ANEXO I}

Plano de curso da disciplina Corporeidade e expressão em Educação Física

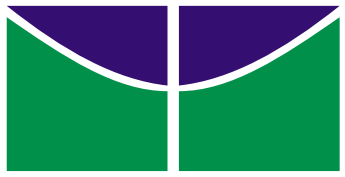

Universidade de Brasília - UnB

Faculdade de Educação Física - FEF

Curso de Graduação em Educação Física

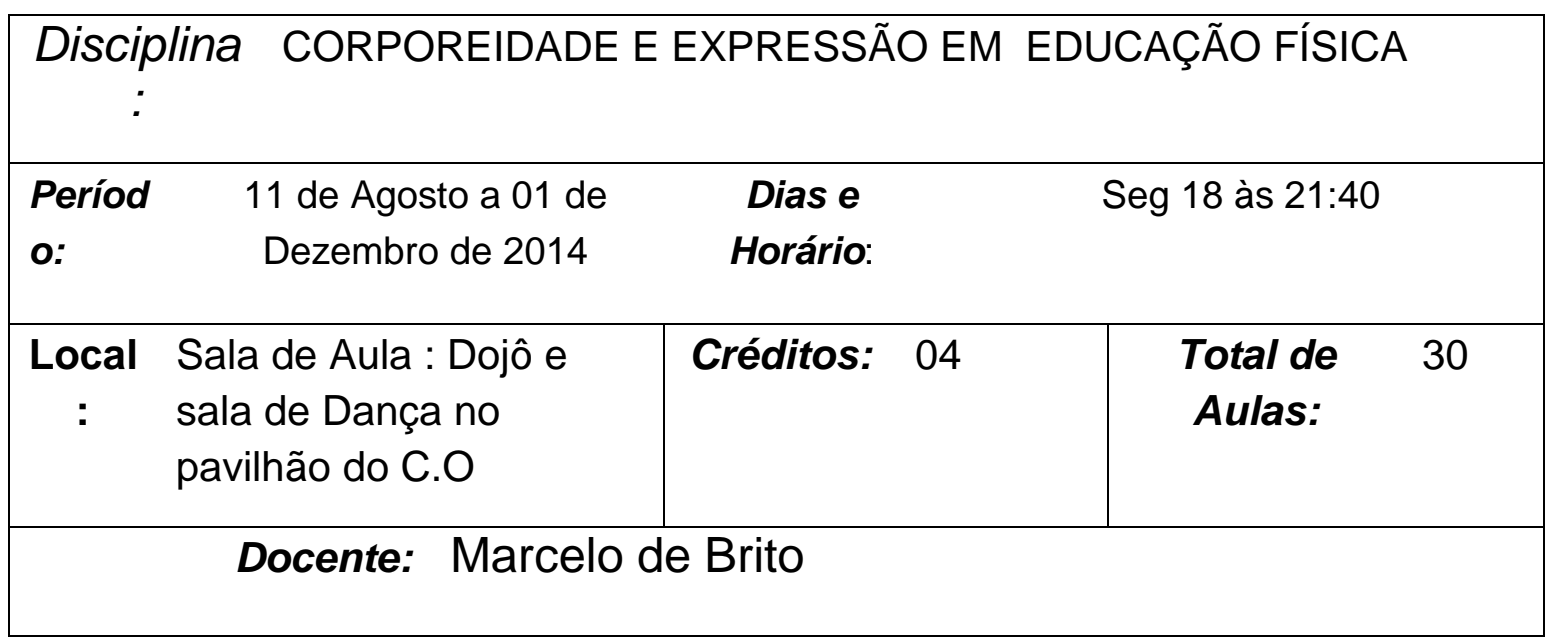

\section{Plano de Curso}

Ementa

EMENTA: Corpo, corporeidade, sensoriedade-sensibilidade, perceção, indivíduo e individuação, cultura do corpo, movimento, expressividade, impressividade.

\section{OBJETIVOS GERAIS}

- $\quad$ Aprofundar a discussão acerca do fenômeno da corporeidade na contemporaneidade à luz da história;

- $\quad$ Estimular a sensibilidade e a perceção integrativa através de motrivivências;

- $\quad$ Ampliar a consciência de si

\section{OBJETIVOS ESPECÍFICOS}

- $\quad$ Estudar o fenômeno da corporeidade na sociedade contemporânea

- $\quad$ Aguçar o aparato sensorial e a perceção.

- Ampliar a expressividade e a impressividade corporal

\section{CONTEÚDO PROGRAMÁTICO OU TEMÁTICAS DE INTERESSE}

- $\quad$ O homem e o corpo: revendo a história da dicotomia corpo-mente

- $\quad$ O corpo, suas potencialiades sensoriais e percetivas

- $\quad$ indivíduo, a sociedade e a busca da integração (unidade)

- Desconstruir padrões para reconstruir o SER 
- $\quad$ O processo do autoconhecimento (individuação)

- Uma praxis para integrar as dimensões fisica, emocional, intelectual, espiritual e social do ser humano

\section{METODOLOGIA}

A praxis da disciplina segue uma abordagem construtivista onde, de acordo com as aspirações e possibilidades do grupo enveredamos por uma leitura crítica do tema CORPOREIDADE revendo aspetos individuais e sociais, históricos e da atualidade para construir meios de ampliação da consciência do próprio indivíduo. As aulas se baseiam em motrivivências que intencionam levar o indivíduo a uma "leitura de si". Serão adotadas técnicas de ensino diversas (diretivas e não diretivas) que envolverão trabalhos individuais e em grupo.

Estudos contextualizados envolvendo observação e prática serão realizados e apresentados à turma em forma ou de painel e/ou seminário.

\section{Menções}

As menções serão dadas em relação ao total de pontos obtidos nas avaliações.

SS Igual ou acima de 9,0

MS De 7,0 a menos de 9,0

MM De 5,0 a menos de 7,0

\begin{tabular}{|ll|ll|l|l|l|l|l|}
\hline II & De 3,0 a menos de 5,0 & Abaixo de 1,0 \\
\hline
\end{tabular}

Estará aprovado o Aluno que obtiver menção final igual ou superior a MM.

Ficará reprovado, com a menção SR, o discente que ultrapassar a 25\% de faltas da carga horária da disciplina.

\section{Critérios de Avaliação (colocar os que serão utilizados)}

- Trabalhos individuais (relatos e observações).

..................

- Realização de práticas e estudos contextualizados

- Participação efetiva, assiduidade, contribuições às aulas.

TOT A L 


\section{Observações Pertinentes}

1. Cada discente deve ocupar-se em manter o seu aparelho de telefone celular desligado durante todas as aulas. É uma questão de educação!

\section{Bibliografia Recomendada}

Aguilar G e Musso A. La meditación como proceso cognitivo-conductual. Suma Psicológica, v.15, n.1, marzo de 2008, p.241-258.

Alves S P. Individuação: uma prospecção a novos paradigmas. Disponível em: $<$ http://www.salves.com.br/txt individuacao.htm>. Acesso em: 18 novembro de 2009.

Alves $\quad$ R. Sobre ciência e sapiência. Disponível em: $<$ http://www.rubemalves.com.br/sobrecienciaesapiencia.htm $>$. Acesso em 19 novembro de 2009.

Amoroso R, Dienes I, Varga Cs (eds). Unified Theories. Oakland: The Noetic Press; 2008.

Amparo N. Considerações sobre as relações entre ética, ecológica e educação ambiental. Revista Vertentes, São João Del-Rey," n.29, p. 242-253, jun. 2007. Disponível em: http://intranet.ufsj.edu.br/rep sysweb/File/vertentes/Vertentes 29/nelcinea amparo.p df. Acesso: 19/09/2011

Arendt H. A Condição Humana. 7ed. Rio de Janeiro: Forence Universitária,1995

Assmann H. Paradigmas educacionais e corporeidade. Piracicaba: Unimep; 1995. Reencantar a educação: rumo à sociedade aprendente. Petrópolis, RJ: Vozes, 1998.

Bateson G.. Natureza e espírito - uma unidade necessária. Lisboa: Dom Quixote; 1987. Bauman Z. Modernidade líquida. Rio de Janeiro: Zahar, 2001

Beggiato C L, Silva S A P S. Educação Física Escolar no ciclo II do ensino fundamental: aspectos valorizados pelos alunos. Universidade São Judas Tadeu e UNIFIEO C. L. Beggiato \& S. A. P. S. Silva S32 Motriz, Rio Claro, v.13, n.2 (Supl.1), p.S29-S35, mai./ago. 2007

Betti, M. Valores e finalidades na Educação Física escolar: uma concepção sistêmica. In: Revista Brasileira de Ciências do Esporte. Santa Maria, v.16, n.1, p 14-21.

Boadella D. Correntes da Vida.2ed. São Paulo: Summus; 1992.

Boechat W. O Corpo Psicóide, a Crise De Paradigma e o problema da Relação corpomente. INSTITUTO DE MEDICINA SOCIAL DA UERJ,PÓS- GRADUAÇÃO em saúde coletiva,TESE DE DOUTORADO. Março de 2004, 
Boff L. Ethos mundial. Brasília: Letraviva; 2000.

Bourdieu P. A dominação masculina. 7ed. Rio de Janeiro: Bertrand Brasil, 2010.

Brandão K. Corporeidade, Sensibilidade e Transdisciplinaridade: o desafio ludopoiético como obra de arte da vida. In: II Congresso Internacional Transdisciplinaridade, Complexidade e Ecoformação. Brasília, 2008.

Brito M, João R. Percepção corporal no esporte. In: Jogo, corpo e escola: Esporte escolar - Módulo de ensino a distância ( Programa Segundo Tempo. Capacitação Continuada especialização). Brasília: UnB/CEAD/Ministério do Esporte. (3); 2004.

CAGIGAL, José Maria. Cultura intelectual e cultura física. Buenos Aires: Editorial Kapelusz,1979.

Caillois R. Os jogos e os homens: a máscara e a vertigem. Lisboa: Cotovia, 1990

Capra F. O ponto de mutação. São Paulo: Cultrix; 1982

O tao da física. 2ed. São Paulo: Cultrix; 1983

A teia da vida. São Paulo: Cultrix; 1996.

Conexões ocultas. São Paulo: Cultrix-Amana Key, 2002

Falando a linguagem da natureza: princípios de sustentabilidade. In: Stone

M, Barlow Z. (orgs) Alfabetização ecológica. São Paulo: cultrix: 2006, p. 46-57.

Carvalho Y M. O "mito" da atividade física. São Paulo: Editora Hucitec, 1998. 133 p.

Castellani L. Educação Física no Brasil : a história que não se conta. Campinas: Papirus, 1994. $93 \mathrm{p}$.

Cavalcanti K. Corporeidade e a ética do sentido da vida na educação: para florescer as sementes da pedagogia vivencial. Revista Recrearte, n.7, Jul. 2007. Disponível em: http://www.iacat.com/Revista/recrearte07.htm Acessado em: 30.11.2011.

Cazeneuve J. Sociologia do rito. Porto: Rés, [19__ ]. 297 p. 105

Cezana J, Souza Neto S. Educação Física e práticas corporais alternativas: o trabalho do corpo em questão. Motriz. 2008, out-dez; (14)4: 462-70.

Coletivo de Autores. Metodologia do ensino da Educação Física. São Paulo: Cortez, 1992. 119 p.

Cunha M S V. Um corte epistemológico, da educação física à motricidade humana. Lisboa: Instituto Piaget; 1999

- Uma reflexão sobre o corpo. In: Rodrigues D.(Edit.) O corpo que (dês)conhecemos. Lisboa: Faculdade de Motricidade Humana; 2005 
A prática e a Educação Física. 2ed. Lisboa: Portugal. Compendium, S/D.

Damásio AR. O Erro de Descartes: Emoção, Razão e o Cérebro Humano. São Paulo: Companhia das Letras, 1996.

. O mistério da consciência. São Paulo, SP: Ed. Companhia das Letras, 2000.

O livro da Consciência. Lisboa: Temas e Debates; 2010.

Damatta R. Carnavais, malandros e heróis: para uma sociologia do dilema brasileiro. Rio de Janeiro: Guanabara, 1990. 172 p.

Daolio J A. Da cultura do corpo. Campinas, SP: Papirus, 1995. 105 p.

A construção cultural do corpo feminino ou o risco de transformar meninas em "antas". In: ROMERO, Eliane(Org.). Corpo, mulher e sociedade.Campinas: Papirus, 1995. p. $99-108$.

Antropologia social e a Educação Física: possibilidade de encontro. In: Carvalho YM \& Rubio K (orgs.) Educação Física e ciências humanas. São Paulo, Hucitec. 2001.

Foucault M. Vigiar e punir: nascimento da prisão. 11ed. Petrópolis: Vozes, 1994.

Freire JB. De corpo e alma. São Paulo: Summus; 1991.

- 'Métodos de confinamento e engorda ( como fazer render mais porcos, galinhas, crianças...)" In: W.W.Moreira (org.) Educação Física e esportes: perspectivas para o século XXI. Campinas, Papirus, 1992. 260 p.

. Educação de corpo inteiro. São Paulo: Scipione, 1994.

Geertz C. A interpretação das culturas. Rio de Janeiro: Guanabara, 1989.

Goldenberg M. Nu \& vestido: dez antropólogos revelam a cultura do corpo carioca. Rio de Janeiro: Record, 2002.

Gonçalves M A S. Sentir, pensar, agir - Corporeidade e educação. 11ed. São Paulo: Papirus, 2008.

Goswami A. Universo autoconsciente. 2ed. São Paulo: Rosa dos Tempos;1998 . A física da alma. São Paulo: Aleph; 2005

HALL, Stuart. A identidade cultural na pós-modernidade. Rio de Janeiro: DP\&A, 2002.

Haramein N. O novo conceito de energia. Disponível em:

http://www.youtube.com/watch?v=5gd3OfhGKt8. Acessado em : 25/09/2011 
Jia YC, Davids K, Hristovski R, Araújo D, Passos P. Nonlinear pedagogy: learning design for self organization neurobiological systems. New Ideas in Psycology. 2011, aug; (29)2: 189-200, Disponível em: http://www.sciencedirect.com/science/article/pii/S0732118X10000607. Acessado em 17 jul 2011

João R, Brito M. Pensando a corporeidade na prática pedagógica em educação física à luz do pensamento complexo. Rev Bras Educ Fís Esp. 2004, Jul-set; 18(3): 263-72.

Johnson D. Corpo. São Paulo: Nova Fronteira, 1990

Maturana H, Varela FJ. A Árvore do Conhecimento. São Paulo: Palas Athenas; 2001 Formação humana e capacitação. 4ed. Petrópolis: Vozes; 2003.

MAUSS, Marcel. Sociologia e antropologia. 2v. São Paulo: EPU/Edusp, 1974.

Merleau-Ponty M. Fenomenologia da percepção. Rio de Janeiro: Livraria Freitas Bastos; 1971.

Morin E. Introdução ao pensamento complexo. $2^{\circ}$ ed.. Lisboa, Portugal: Instituto Piaget, 1990. América, 1996.

O método III: o conhecimento do conhecimento. Lisboa: Europa.O método I. Lisboa: Publicações Europa-América; 1997.

. O Método II - A vida da vida. Portugal. Publicações Europa-América, 1999. América, 2000.

. O paradigma perdido - a natureza humana. Lisboa: Publicaçoes Europa. Os sete saberes necessários à educação do futuro. São Paulo: Cortez; Brasília, DF: UNESCO, 2000 . O método 6: ética. Porto Alegre: Sulina; 2005.

Motoyama H. A teoria dos chakras: ponte para a consciência superior. 5ed. São Paulo: Pensamento; 2001.

Nóbrega TP. Corpo, percepção e conhecimento em Merleau-Ponty Estudos de Psicologia 2008, 13(2), 141-148

Reichow J. Consciência e transdisciplinaridade. In: 1 Simpósio Nacional Sobre Consciência,.., 2006, Salvador. Anais... Salvador:Fundação Ocidente, 2006. 
Rodrigues D (Edit.). O corpo que (dês)conhecemos. Lisboa: Faculdade de Motricidade Humana; 2005

Santin S. Educação Física - uma abordagem filosófica da corporeidade. Ijuí: Unijuí; 1987.

SANTIN S. Educação Física: outros caminhos. Porto Alegre: EST, 1990

Schiller F. A educação estética do homem. São Paulo: Iluminuras; 1995.

Sheldrak R. A Presenca do Passado: Ressonância Mórfica. Lisboa: Instituto Piaget, 1996.

Silva JC. Sócrates e a autotranscendência. Disponível em:<http://educacao.uol.com.br/filosofia/conhece-te-a-ti-mesmo.jhtm>. Acesso em 19 de novembro 2009.

SOUSA, Jose Antunes Motricidade Humana: um nome ou um projeto de vida? Disponível em: http://pt.scribd.com/doc/56972035/Sousa-Jose-Antunes-MotricidadeHumana\#outer page 16. Acesso virtual em: 23.10.2011

Tolle E. O despertar de uma nova consciência. Rio de Janeiro: Sextante, 2007.

Werneck CLG. Educação Física: Novos olhares sobre o corpo. In: SOUZA, Eustáquia Salvadora \& VAGO, Tarcício Mauro (orgs.). Trilhas e partilhas: Educação Física na cultura escolar e nas práticas sociais. Belo Horizonte: Gráfica e Editora Cultura Ltda, 1997. 387

p.

http://www.motricidade.com/index.php?option=com content\&view=article\&id=124:aaccao-pedagogica-do-professor-de-educacao-fisica-pos-

graduado $\&$ catid $=48:$ docencia $\&$ Itemid $=90$

Wilber K. Uma Teoria de Tudo: uma visão integral para os negócios, a política e a espiritualidade. São Paulo: Cultrix, 2003.

A união da alma e dos sentidos: integrando ciência e religião. SP: Cultrix, 2006.

\section{BIBLIOGRAFIA COMPLEMENTAR}

Betti, M. Educação Física e sociedade. São Paulo: Movimento, 1991. 182 p.

Calegari D. Bases Rechianas. São Paulo, 2003. Mimeo

Cuche D. A noção de cultura nas ciências sociais. Bauru: EDUSC, 2002. 255p.

Entralgo PL. O que é o homem. Lisboa: Editorial Notícias, 2002

Cuerpo y alma. Madrid: Editorial Espasa Calpe; 1992. 
Goleman D, Gurin J. Equilbrio mente-corpo. Rio de Janeiro: Campos;1997.

Huard L, Wong L. Cuidados e técnicas com o corpo. São Paulo: Summus;1990.

Lipton B. A biologia da crença. São Paulo: Butterfly, 2007.

Moraes MC. Pensamento eco-sistêmico: educação, aprendizagem e cidadania no século XXI. Petrópolis: Vozes; 2004.

Naranjo C. Mudar a educação para mudar o mundo. São Paulo: Esfera, 2005. La mente patriarcal. Barcelona: RBA Libros, 2010.

OSHO. Aprendendo a silenciar a mente. Rio de Janeiro: Sextante, 2002

Osho. Meditação: a primeira e última liberdade. Lisboa, Bertrand; 2009.

Ouspenski, P.D. Fragmentos de um ensinamento desconhecido (em busca do milagroso). São Paulo: Pensamento. S/D.

Peirano M. Rituais ontem e hoje. Rio de Janeiro: Zahar; 2003.

Poopel E. Fronteiras da Consciência: a realidade e a experiência do mundo. O agora. Edições 70. Lisboa, Portugal; 1985.

Rohden H (Lao Tsé). Tao Te King - o livro que revela Deus. São Paulo: Martins Claret; 2003.

Sabetti S. O princípio da totalidade. São Paulo: Summus; 1991.

Schpun MR. Beleza em jogo. São Paulo: Editora Senac, 1999.

Segalen M. Ritos e rituais contemporâneos. Rio de Janeiro: Editora FGV, 2002. 161 p.

Soares CL. Corpo e história. Campinas, SP: Autores Associados, 2001.

Sousa JA. Vergílio Ferreira e a filosofia da sua obra literária. Lisboa: Instituto Piaget, 2008.

Varga Cs. Unified Theory: metaphilosophy. In Amoroso R, Dienes I, Varga Cs (eds). Unified Theories. Oakland: The Noetic Press, 2008.

OBS: Material advindo de periódicos serão utilizados ao longo da disciplina, mas que não estão aqui relacionados. As fontes serão apresentadas ao longo do semestre. 


\section{ANEXO II}

\section{PROJETO DE EXTENSÃO: AÇÃO CONTÍNUA}

Ano:
Semestre: (X ) 1ㅇ ( ) 20

1. IDENTIFICAÇÃO

\subsection{Título do Projeto/Atividade}

MOVI-MENTE

1.2. Área Temática Principal (informações sobre as áreas - clique aqui)
( ) Comunicação
( ) Cultura
( ) Direitos Humanos e Justiça
(X) Educação
( ) Meio Ambiente
( ) Saúde
( ) Tecnologia e Produção ( ) Trabalho

\subsection{Coordenador:}

Nome: MARCELO DE BRITO

Unidade de lotação:FEF

Cargo/Titulação:PROFESSOR/DOUTOR

Fax:

Telefone:

E-mail:swkapish@unb.br

1.4. Características da execução:

Multidisciplinar:

( ) Não

(X) $\operatorname{Sim}$

Disciplinas envolvidas（）2 ( ) 3

Interinstitucional: ( ) Não $\quad(x) \operatorname{Sim}$

Equipe: $(\mathrm{X})$ Docentes $\quad(\quad$ Técnicos administrativos

(X) Alunos

( ) Participantes externos

Data de (re) início:

12 08 /_2013

Data de término: I 
Local da execução:CENTRO OLÍMPICO/FEF

OBS: O projeto Movi-mente não segue uma lógica de terminalidade. Pausas são realizadas no período de férias acadêmicas porém as atividades retornam com o inicio do semestre letivo.

\subsection{Caracterização da clientela/público:}

X ) Externa e interna ( ) Somente externa ( ) Somente interna

) Categorias profissionais específicas: citar:

\section{VÍNCULO ACADÊMICO}

\subsection{Unidade Executora: FEF}

Curso:Educação Física

\subsection{Atividades relacionadas: Disciplina(s):}

) Estágio ( ) Projeto especial (X) Pesquisa ( ) Graduação ( ) Pós-graduação (X) Outros

\subsection{Interface com outro(s) curso(s):}

Departamento(s):

Disciplina(s):

\section{CARACTERIZAÇÃO DO PROJETO}

3.1. ( ) Novo (X) Renovação
Relatório do ano anterior: ( X ) Sim
( ) Não

\subsection{Origem:}

(X) Iniciativa do grupo de execução （ ) Demanda da comunidade

\subsection{Multidisciplinariedade:}

Áreas envolvidas: O projeto Movi-mente é multifacetado podendo ser relacionado a varias outras áreas como educação, artes, saúde, serviço social, psicologia. 


\subsection{Instituições envolvidas/Tipo de participação:}

No segundo semestre de 2013 pretendemos interagir com as seguintes instituições: Escola de ensino médio-CEAN e Núcleo de reclusão feminina da Colméia. Manteremos também uma interface com o Projeto Atividade física e Parkinson

\section{JUSTIFICATIVA}

Numa sociedade em estado de crise, a preservação dos valores humanos, da ética, da ecologia merecem detida atenção pois são orientam possibilidades de ampliação de uma vivência e de uma convivência dignas. Neste sentido, a busca do autoconhecimento (consciência de si) é uma emergência na atualidade O desenvolvimento da consciência de si (metanóia), assim entendemos, representa o caminho para preservar e melhorar as condições de nossa existência. Este intento está evidenciado em diversos contextos e mecanismos da sociedade. 0 corpo, neste contexto, representa, em nossa compreensão, a base para realização dessa busca.

Há quase duas décadas desenvolvendo estratégias direcionadas para esse objetivo, vimos constatando que a atividade corporal constitui um eixo fundamental no processo de autodescoberta.

O Movi-mente amparado em experiências abertas de educação motora é um projeto que constutuiu-se numa oportunidade ímpar de auto-conhecimento.

\section{OBJETIVOS}

- Estimular o desenvolvimento humano e a consciência de si;

- Estabelecer um lócus para o estudo e desenvolvimento de novas estratégias de trabalho corporal na perspectiva da complexidade;

- Estabelecer um espaço/tempo para a comunidade em geral experienciar rupturas nos padrôes cotidianos através do trabalho corporal e da meditação dinâmica

\section{METODOLOGIA}


Baseado em uma proposta aberta de ensino, experiêncas corporais (motrivivências) são desenvolvidas almejando a ampliação da percepção visando a consciência corporal e a meditação. $O$ trabalho é desenvolvido em sessões de 2 a 3 horas de atividade.

Baseada numa abordagem de trabalho singular desenvolvida no próprio Movi-mente (Brito, 2013), as práticas buscam numa perspectiva não linear a ruptura com os padrões comportamentais do cotidiano.

As atividades emergem como fruto da capacidade criativa do mediador e do grupo em função da situação do Agora que se contextualiza. Assim sendo, os indivíduos são convidados, a cada encontro, a uma experiência inusitada. A praxis segue um fluxo que envolve ação-observação- reflexão-inação e fundamentam-se no Kaos criativo, no jogo, na formação de um campo harmônico de interações que visam ativar a bio-energia da corporeidade em todas as dimensões (física, emocional, mental, espiritual e social)

\section{CLIENTELA}

(Caracterização e número estimado)

o público que freqüenta as práticas é eclético e vai desde jovens acima de 15 anos até a terceira idade. Em geral, o grupo frequentador compõe-se de jovens entre 20 e 30 anos. O número de participantes é aberto, mas normalmente gira em torno de 30 a 40 pessoas.

A partir de 2013 ampliaremos a oferta do projeto para jovens que estão cursando o ensino médio, para mulheres em estado de reclusão e para portadores da doença de Parkinson.

\section{AVALIAÇÃO}

(Descrição do sistema de avaliação, qualitativa e quantitativa)

A avaliação segue uma perspectiva eminentemente qualitativa. Relatos espontâneos e induzidos, rodas de troca de experiência, entrevistas abertas, trocas via internet e entrevistas com os particiipantes são os mecanismos utilizados para assegurar o curso da proposta. Circunstancialmente, relatos por escrito das experiências e da trajetória pessoal são requisitados para documentar os processos de desenvolvimento.

Testes específicos para aferição de competencias corporais, aspectos psicológicos e sociais devem passar a fazer parte da coleta de dados como fundamento para pesquisas e produção acadêmica introduzindo no contexto avaliações quali-quantitativas.

\section{SOCIALIZAÇÃO DO CONHECIMENTO}

(Produtos a serem gerados: a) de natureza cientifica: monografias, teses, publicações, etc; b) de natureza artística: 
oficinas, produtos artísticos, etc.)

Alguns produtos já foram constituídos em forma de artigos e apresentações em congresso. A experiência do Movimente orientou a tese de doutorado Brito $\mathrm{M}$. A construção do sentimento de unidade: desdobramentos de uma abordagem corporal atípica no desenvolvimento humano. [Tese de doutorado] UTAD-Portugal, 2013.

Encontra-se à disposição da Revista Pensar a Prática (UFGO), o artigo entitulado: Educar para a consciência da unidade.

Outros 3 artigos encontram-se em fase de conclusão e devem ser submetidos no segundo semestre de 2013.

\section{EQUIPE DE TRABALHO}

\begin{tabular}{|c|c|c|c|c|c|}
\hline Nome & $\begin{array}{l}\text { Categoria } \\
\text { funcional }\end{array}$ & $\begin{array}{l}\text { Lotação (depto } \\
\text { /órgão/centro) }\end{array}$ & Matrícula & $\begin{array}{c}\text { Titulação/ } \\
\text { Qualificação }\end{array}$ & $\begin{array}{l}\text { Natureza da } \\
\text { participação }\end{array}$ \\
\hline \begin{tabular}{|l} 
1) Marcelo de Brito \\
\end{tabular} & $\begin{array}{l}\text { Prof. } \\
\text { Prof. }\end{array}$ & $\begin{array}{l}\text { FEF } \\
\text { FEF }\end{array}$ & 913006 & $\begin{array}{l}\text { Doutor } \\
\text { Mestre }\end{array}$ & $\begin{array}{l}\text { Coordenação, } \\
\text { organização, } \\
\text { orientação e } \\
\text { execução. } \\
\text { Subcoordenaç } \\
\text { ão,organizaçã } \\
\text { o e orientação }\end{array}$ \\
\hline \multicolumn{6}{|l|}{ 2)Renato Bastos João } \\
\hline \multicolumn{6}{|l|}{ 3) } \\
\hline \multicolumn{6}{|l|}{ 4) } \\
\hline 5) & & & & & \\
\hline
\end{tabular}

11. CRONOGRAMA DE EXECUÇÃO

\begin{tabular}{|l|l|l|l|l|l|l|l|l|l|l|l|l|}
\hline \multirow{2}{*}{ Etapas } & Meses jan & Fev & Mar & Abr & mai & jun & jul & ago & set & out & Nov & dez \\
\hline & & & & & & & & & & & & \\
\hline 1) Elaboração do projeto & & & & & $x$ & & & & & & & \\
\hline 2) Encaminhamento do projeto & & & & & & $x$ & & & & & & \\
\hline 3)início do projeto & & & & & & & & $x$ & & & & \\
\hline
\end{tabular}




\begin{tabular}{|l|l|l|l|l|l|l|l|l|l|l|l|l|}
\hline 4)conclusão do ciclo semestral & & & & & & & & & & & & $x$ \\
\hline 5)recomeço & X & & & & & & $X$ & & & & \\
\hline
\end{tabular}

Os ítens 12 e 13 são referentes a despesas. Como não há previsão orçamentária excluí estes itens.

\section{ANEXOS}

( ) Curriculum vitae dos participantes externos.

) Documento comprovante de adesão dos parceiros de execução.

) Documento comprovante de cooperação do município-sede.

) Documento registrando demanda da comunidade que motivou o projeto.

) Ficha cadastral: palestrantes, instrutores e professores externos (ou curriculum vitae resumido).

Data: I 
Nome do Projeto: MOVI-MENTE

Coordenador e executor: Marcelo de Brito

PARECER DO COORDENADOR DE EXTENSÃO (No parecer deve constar: adequação do projeto às normas do DEX; compatibilidade entre a área do coordenador do projeto e a atividade proposta; compatibilidade da receita e despesa (quando houver); encaminhamento de informação adicionais previstas no quadro de ANEXOS, mérito da proposta.)

Aprovado（） Sim （） Não

Data:

Matrícula: 
acadêmicos e a relevância do projeto; a disponibilidade do coordenador da proposta para desenvolver o projeto.)

Reunião do Colegiado №:

Data:

Assinatura do Presidente do Colegiado:

Cargo:

Matrícula: 


\section{Anexo III}

Temas das reflexões escrita pedidas pelo professor Marcelo de Brito ao longo do semestre no curso Corporeidade.

1. Carta ao corpo: $\mathrm{O}$ estudante deve escrever uma carta a seu próprio corpo.

2. O que é Corporeidade?

3. Quais são seus padrões inconscientes? O que fazer para superá-los?

4. Auto-avaliação: O que você aprendeu em Corporeidade? 


\section{APÊNDICES}

\section{Apêndice I}

\section{Roteiro de observação}

1. Momento teórico

Durante as aulas os elementos a serem observados pelo pesquisador são:

- Frequência dos alunos

- Resposta às perguntas elaboradas pelo professor

- Interatividade entre professor e aluno

- Interatividade alunos-alunos

- Conduta e didática do professor em relação ao clima criado dentro de sala de aula

- Conduta do professor em relação aos alunos e seus saberes

- Configuração da sala de aula, organização do espaço

- Interesse e participação dos alunos em relação ao que está acontecendo dentro de sala

- Reação e expressão dos estudantes durante as aulas teóricas em relação aos assuntos polêmicos como: espiritualidade oriental, consciência, real e realidade, reencarnação e outros.

2. Momento prático

- Assiduidade dos alunos nos momentos práticos

- Participação e resposta aos comandos dados pelo professor dentro do projeto Movimente

- Permanência dentro da Sala de Dança durante a prática

- Expressões dos alunos diante daquilo que é pedido pelo professor

3. Imersões

- Interações com outros participantes da imersão 
- Expressões e reações diante daquilo que é requerido nas motriviências

- Nuances entre a chegada e a saía da imersão 


\section{Apêndice II}

Instruções enviadas por correio eletrônico aos sujeitos de pesquisa sobre o que escrever no diário.

Olá, bom dia!

Sobre os diários, existem duas ocasiões em que eu gostaria que vocês escrevessem nele. Mas vocês para além delas vocês podem escrever o que tiverem vontade.

\section{Como foi a aula de Corporeidade? Como foi o Movi-mente?}

O que você sentiu? Que momento foi forte? Por que foi forte? Como você estava se sentindo quando chegou? Como você estava se sentindo quando saiu? Algo se alterou? O que? Por quê?

Trata-se de explicar minuciosamente aquilo que você vivenciou na sua aula e prática. Fiquem a vontade para abrir as profundezas do coração. Pensem nisso como um processo terapêutico, com possibilidades de tomarem consciência de si mesmo, ampliando suas potencialidades e superando suas limitações.

\section{Caso durante a semana ocorrer alguma situação que lhe lembre o Movi-mente.}

Se no seu cotidiano, você perceber que por algum motivo você se lembrou de algo que ocorreu no Movi-mente ou na aula, escreva no caderno esta situação que o fez lembrar do Movi-mente e descreva com detalhes o porque que você acreditar ter lembrado. Enfim, narre o que ocorreu e narre sua reflexão sobre o acontecido. Fique a vontade par a compartilhar

Não é preciso se restringir a responder as perguntas que coloquei. No diário vocês tem liberdade para escrever o que quiserem.

Agradeço a participação.

Abraço,

Victor. 


\section{Apêndice III}

\section{Eixos norteadores das dinâmicas conversasionais}

História de vida: Neste eixo nos direcionamos de modo a investigar a vida do indivíduo, onde nasceu, onde viveu sua infância e adolescência, como era a relação com a família. Aqui também conversamos sobre os gostos da pessoa é a onde buscamos investigar o que essa pessoa pensa de si mesma e do mundo que vive.

Escolha da graduação e processo de graduação: Este eixo busca investigar como foi o processo de tomada de decisão em relação ao curso de graduação. Buscamos compreender como a pessoa se sentia previamente antes de entrar o curso, como ela está vivenciando sua graduação, como se sente em relação ao futuro de seu curso, quais perspectivas o curso lhe abriu,

Diálogos sobre Corporeidade e Movi-mente: Neste eixo buscamos investigar como a pessoa experiência a curso/projeto, como está sendo este processo para ela, de que forma este processo está mexendo com ela, o que ela tem percebido sobre si mesma, o que é bom, o que é ruim, qual foi o processo de escolha da curso/projeto, o que a o indivíduo pensa da curso/projeto. Aqui transitamos tanto por diálogos sobre os aspectos teóricos da curso/projeto e como sobre o momento prático práticas, buscando perceber como o indivíduo integra os dois momentos e qual é o nível de profundidade e familiaridade que ele possui com os aspectos teóricos da disciplina. Neste eixo também exploramos como foi o processo de escolha e aproximação da disciplina, expectativas e percepções.

Quem sou? De onde vim? Para onde vou? Busca por compreender como a pessoa percebe a si mesmo em sua trajetória, como vê o mundo e como se organiza para se relacionar com ele. Este tópico também busca compreender como a pessoa está vivendo seu momento atual, o que tem feito, quais tem sido seus conflitos, como a pessoa se situa diante de seus conflitos, como se sente em relação a vida e aos próprios objetivos. 


\section{Apendice IV}

\section{COMPLETAMENTO DE FRASES}

Complete as frases abaixo com a primeira ideia que surgir na sua mente:

1.Eu gosto...

2. O tempo mais feliz...

3. Gostaria de saber...

4. Lamento...

5. Meu maior medo...

6. Meu corpo...

7. Não posso...

8. Sofro...

9. Fracassei...

10. A coisa mais importante...

11. Meu futuro...

12. No Movi-mente...

13. Meu caminho...

14. Algumas vezes...

15. Este lugar...

16. A preocupação principal...

17. Desejo...

18. Corporeidade...

19. Secretamente eu...

20. Eu...

21.Meu maior problema é...

22.0 trabalho...

23.Amo...

24. Estou melhor...

25.Eu prefiro...

26.Meu problema principal...

27.Quero ser...

28.Creio que minhas melhores atitudes são...

29. Nesse ano...

30.A felicidade

31. Quando acontece algum imprevisto...

32. Esforço-me diariamente por...

33.Sinto dificuldade...

34.Meu maior desejo...

35.Sempre quis...

36.Gosto muito...

37.Minhas aspirações são...

38. Nos últimos meses tenho me sentido...

39.Minha vida futura...

40.Farei o possível para alcançar...

41.Frequentemente, reflito sobre...

42.Proponho-me a... 
43.Meu maior tempo dedico a...

44.Sempre que posso...

45.Luto...

46. Frequentemente, sinto...

47.Diante de situações novas...

48. No início o ano...

49.Esforço-me...

50.As contradições...

51.Minha opinião...

52.Penso que as pessoas...

53. Espero...

54.Incomoda-me...

55.Ao deitar-me...

56.A gente...

57.Decidi que...

58. Meus estudos...

59. Percebo mudanças...

60. Considero que posso...

61.Quando tenho dúvidas...

62.No futuro...

63. Necessito...

64.Minha principal ambição...

65.Odeio...

66.Quando estou só...

67.Meu maior temor...

68.Se trabalho...

69.Deprimo-me...

70.0 estudo...

71.Meus amigos...

72.Meu grupo...

73.0 ser humano...

74.Não me sinto preparada... 
Apêndice V

\section{COMPOSIÇÃO}

Escreva um texto com o tema: Quem sou eu 